\title{
The ENGINEERS CASE CENTENARY: SCOTUS AND THE ORIGINS OF AUSTRALIA'S Scabrous Constitutional Signature
}

\author{
Benjamen Franklen Gussen* \\ Sahar Araghi**
}

\begin{abstract}
Since the Engineers Case decision in 1920, the role of the United States Constitution in interpreting the Australian Constitution has been diminished, leading to inefficiencies in High Court of Australia (HCA) dealing with constitutional issues. To explain this thesis, the article looks at the 7,657 cases decided by the HCA, from the first case in 1903, to the 31st of August 2020, the centenary of the Engineers Case. The analysis identifies outliers that have much higher complexity (in terms of wordlength) than the other judgments. This complexity has one common denominator: comparative analysis with the United States Constitution. The article explains why this common denominator has resulted in such complexity, and concludes with possible research extensions on the roles of the Australian judiciary in embracing SCOTUS jurisprudence when interpreting the Australian Constitution.
\end{abstract}

\section{KEYWORDS}

High Court of Australia (HCA), Supreme Court of the United States (SCOTUS), The Engineers Case, Constitutional Signature, Complexity

\section{CONTENTS}

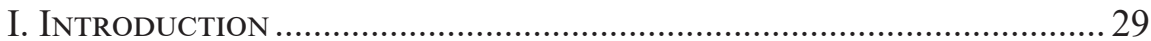

II. Overview of High Court Cases 1903-2020 ................................... 31

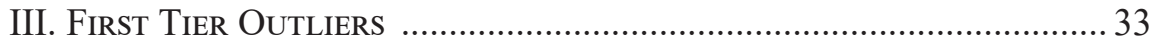

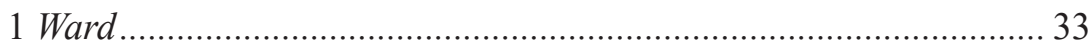

2. Work Choices Case .................................................................. 36

* Dr. Benjamen Gussen is the President of the Australian Law and Economics Association (www.austlea.org) and a constitutional jurist at the School of Law, Swinburne University of Technology, Melbourne, Australia.

** Dr. Sahar Araghi is a data scientist in the Centre for Transformative Innovation (CTI) at the Swinburne University of Technology.

The authors would like to thank Jane O'Donnell from the Swinburne University Library and Jennifer Allison from the Harvard Law School Library for their valuable comments on an earlier version of this article, as well as their contribution in readying the article for publication. 


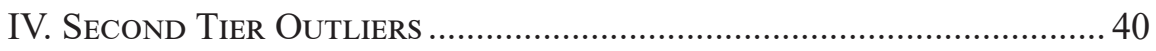

1. Tasmanian Dam Case ................................................................. 40

2. Bank Nationalization Case ......................................................... 45

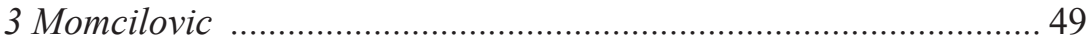

4. Coal Vend Case ………............................................................. 52

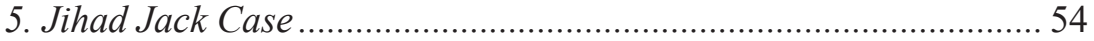

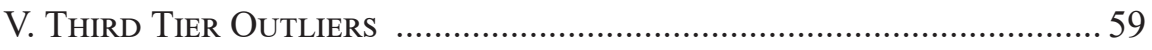

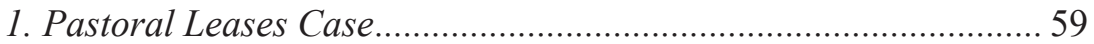

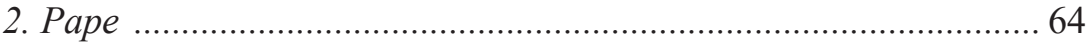

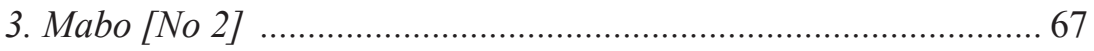

4. War Crimes Act Case ............................................................... 70

5. School Chaplains Case .............................................................. 76

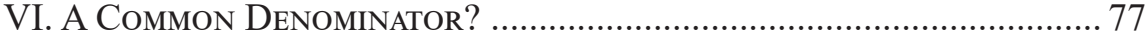

VII. REMOVING THE INEFFICIENCY IN INTERPRETING THE AUSTRALIAN

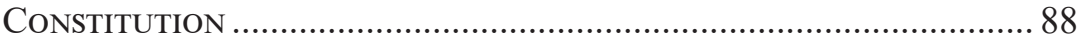

7.1. The Lingering Effect of the Engineers Case ………………........ 90

7.2. The Proposed Approach............................................................ 91

7.3. An Application of the Proposed Approach................................... 98

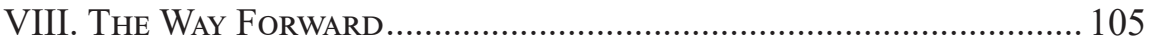




\section{INTRODUCTION}

Australia is the youngest of the three great Anglo-American federations, which allowed the framers of its Constitution ${ }^{1}$ to borrow from the federal designs found in the United States and Canada. The vertical distribution of legislative powers in the Australian Constitution, however, is designed after the US model, where the residual powers are assigned to the States rather than to the federal government as found in the Canadian Constitution. ${ }^{2}$ The original intention of the framers was to afford Australians the same protections provided US citizens. However, looking back at over 100 years of High Court of Australia (HCA) jurisprudence under what came to be known as the Engineers Case, ${ }^{3}$ the analysis suggests an emerging constitutional crisis, where the interpretation of the Australian Constitution is leading to inefficiencies in resolving a number of key constitutional issues.

The issue is the marginalization of the role of United States jurisprudence in interpreting the Australian Constitution. In designing the Australian Constitution, the framers relied heavily on the United States Constitution, and (arguably) to a lesser extent on the Canadian Constitution, and on British constitutional doctrines, such as responsible government. ${ }^{4}$ The reliance on United States jurisprudence in interpreting the Australian Constitution was also a distinctive feature of HCA reasoning in its early days. Over time, however, especially after the Engineers Case, the HCA visited United States jurisprudence mostly only to distinguish how the Australian Constitution should be interpreted from the interpretation of the United States Constitution.

To explain this emerging constitutional crisis, the article furnishes specific evidence of the complexity inherent in the analysis of Australian (Commonwealth) constitutional law. The analysis is focused on the HCA given its original constitutional jurisdiction under section 76(1) of the Australian Constitution. ${ }^{5}$ This is not the first article that offers empirical analysis of the judgments of Australian courts. ${ }^{6}$ However, the article is novel in that it provides statistical evidence as to

Commonwealth of Australia Act, 1900 (Imp), 63 \& 64 Victoria, c. 12, § 9 (U.K.).

For a detailed analysis of this point, see Benjamen Franklen Gussen, Axial Shift: City-Subsidiarity in the 21st Century 391-414 (2019).

3 Amalgamated Soc'y of Eng'rs v Adelaide SS Co Ltd ("Engineers Case”) (1920) 28 CLR 129 (Austl.).

4 See Benjamen Franklen Gussen, On the Hardingian Renovation of Legal Transplants, in Legal Transplants in EAst Asia AND Oceania 84 (Vito Breda ed., 2019); Benjamen Franklen Gussen, Reflections on La Fata Morgana: Watsonian "Prestige" and Bagehotian "Efficiency", 12 J. CoMP. L. 80 (2017).

5 The Australian Law Reform Commission has described the inclusion of constitutional matters in s 76 rather than s 75 as "an odd fact of history." See AusTraLian LAW REFORM Commission, AlRC Report 92, Judicial Power of the Commonwealth: A Review of THE Judiciary ACt 1903 AND Related Legislation 258, ๆ 12.16 (2001):

Most observers of the judicial system would regard constitutional adjudication as one of the most important tasks of the High Court. It is an odd fact of history that a jurisdiction now regarded as essential to the role and function of the High Court should not be listed in the Court's entrenched jurisdiction under s 75 of the Constitution. Rather, conferral of that jurisdiction on the High Court is at the discretion of Parliament under s 76(i).

6 See, e.g., Russell Smyth \& Mita Bhattacharya, What Determines Judicial Prestige? An 
the complexity of constitutional legal issues, using all High Court cases, from the very first case, ${ }^{7}$ up to the last case decided before the Engineers Case centenary (31 August 2020). ${ }^{8}$

As to the optimal interpretive approach, the article proposes moving beyond the traditional common law approach to interpreting the Australian Constitution and returning to the originalist approach that cleaves particularly closely to United States jurisprudence. An example is the Janus-faced approach to international law in Australia, ${ }^{9}$ a smiling internationally-turned face, and a frowning nationallyturned face. Hence, while the executive government is interested in participating in international treaties, once the treaty is signed, "there is usually some reluctance to actually implement the treaty into domestic law", ${ }^{10}$ with more concern "typically expressed about international legal standards relating to the environment or human rights, but it is much more rarely articulated about international laws relating to trade and business." 11 This Janus-faced approach is partly because of the lack of references to international law in the Australian Constitution, save for the external affairs power in section 51(xxix) and the grant of jurisdiction to the HCA by section 75(i) in matters "arising under any treaty." 12 A harmonization with SCOTUS jurisprudence can reduce the complexity of interpreting these sections of the Australian Constitution. Article VI of the United States Constitution explains that "all Treaties ... shall be the supreme Law of the Land", without transformation, balanced by "a considerable reluctance to enter into treaties (to some extent the result of the constitutional procedure for treaty participation)."13

The article proceeds as follows. Section II provides an overview of all HCA cases from 1903-2020 (inclusive). Sections III to V discuss the HCA cases with the highest complexity. Section VI provides a synthesis of the preceding analyses. Section VII discusses the optimal approach to interpreting the Australian Constitution. The last section outlines our future research in relation to the findings.

Empirical Analysis for Judges of the Federal Court of Australia 5 Am. L. \& ECON. Rev. 233 (2003); Andrew Lynch, The Gleeson Court on Constitutional Law: An Empirical Analysis of its First Five Years, 26 U. N.S.W. L. J. 32 (2003); Paresh Kumar Narayan \& Russell Smyth, What Explains Dissent on the High Court of Australia? An Empirical Assessment Using a Cointegration and Error Correction Approach, 4 J. EMPIRICAL LegAL STUD. 401 (2007).

7 Dalgarno v Hannah (1903) 1 CLR 1 (Austl.) (decided 11 November 1903).

$8 \quad$ Mondelez Austl Pty Ltd v Automotive Union (2020) 94 ALJR 818 (Austl.) (decided 13 August 2020).

9 Hilary Charlesworth, International Law and Australian Law in the 21st Century, 6 NewCastle L. Rev. 1, 4 (2002).

10 Id. at $1,4$.

11 Id.

12 Id.

13 Id. (citing the U.S. ConsT. art. VI. But see Chief Justice Marshall's comments in Foster v. Neilson, 27 U.S. (2 Pet.) 253, 313-14 (1829)). The proposed harmonization is not a normative statement, but one approach to reduce the observed complexity, in line with the first issue as to the relevance of US jurisprudence. See also, Hilary Charlesworth et al., Deep Anxieties: Australia and the International Legal Order, 25 Sydney L. Rev. 423 (2003). 


\section{Overview of High Court CaSes 1903-2020}

The article tests the hypothesis that constitutional analysis in Australia exhibits a level of complexity significantly higher than that seen in other substantive and procedural areas of law. The article uses a metric that can capture the complexity of constitutional law efficiently, opting for "a deceptively simple yet powerful characteristic" 14 of legal judgments: their length. Cases with constitutional issues necessitate more complex legal analysis, which could be measured by the length of these cases in words.

Figure 1 provides the complexity of HCA judgments from 1903-2020 (inclusive). During this period, there were 7,657 judgments. The word 'scabrous' in the title refers to the rough surface seen in Figure 1. In other words, we can see spikes in the length of judgments that resemble the prickly hairs on the surface of cactus leaves.

The term 'constitutional signature' (in the title to this article) refers to the relationship between the distinctive spikes seen in Figure 1, and the constitutional issues identified by the HCA in the catchwords of each case. ${ }^{15}$ The article uses these words as reported by the HCA, rather than by other law reports. The designation of an issue as constitutional means that the legal analysis relates to the Australian Constitution or to one of the state constitutions. Some issues, while also discussing constitutional issues as human rights, are not designated as constitutional given that the legal analysis is based on instruments other than the federal and state constitutions. For example, the extinguishment of native title could be considered as relating to a constitutional issue. However, its analysis is based on the NTA ${ }^{16}$ and related common law doctrines. Therefore, extinguishment of native title is reported by the HCA under a separate heading (aboriginals). ${ }^{17}$

The HCA judgments in the observation period $(1903$ - 2020) were ranked based on their length, and the outliers were defined as cases with a length roughly ten times the average length of all cases in the observation period. The justification for this definition comes directly from Figure 1 and the distribution of cases with a length of 80,000 words or above.

One can identify three tiers of outliers in Figure 1. The first has judgments with length over 120,000 words. The second tier has judgments with length above 100,000 but below 120,000 words. The third tier has judgments between 80,000 and 100,000. Table 1 lists the 12 outliers (ranked chronologically).

Note how it took eight years to get to the first outlier (from the beginning of HCA sitting in 1903). It then took 37 year to get to the second outlier, and 35 years to get to the third. After that, it took only eight year to the fourth outlier, and only one year to get to the fifth. This shorter period between outliers continued until

14 Ryan C. Black \& James F. Spriggs, An Empirical Analysis of the Length of U.S. Supreme Court Opinions 45 Hous. L. Rev. 621, 624 (2008); Dietrich Fausten et al., A Century of Citation Practice on the Supreme Court of Victoria, 31 Melbourne U. L. Rev. 733 (2007).

15 As recorded by the Australian Legal Information Institute (Austlii) (High Court of Australia Cases, Australian Legal Information Institute, https://www.austlii.edu. au/cgi-bin/viewdb/au/cases/cth/HCA/ (last visited June 3, 2020)).

16 Native Title Act 1993 (Cth) ("The NTA") (Austl.).

17 See, e.g., Western Australia v Ward (2002) 213 CLR 1 (Austl.). 


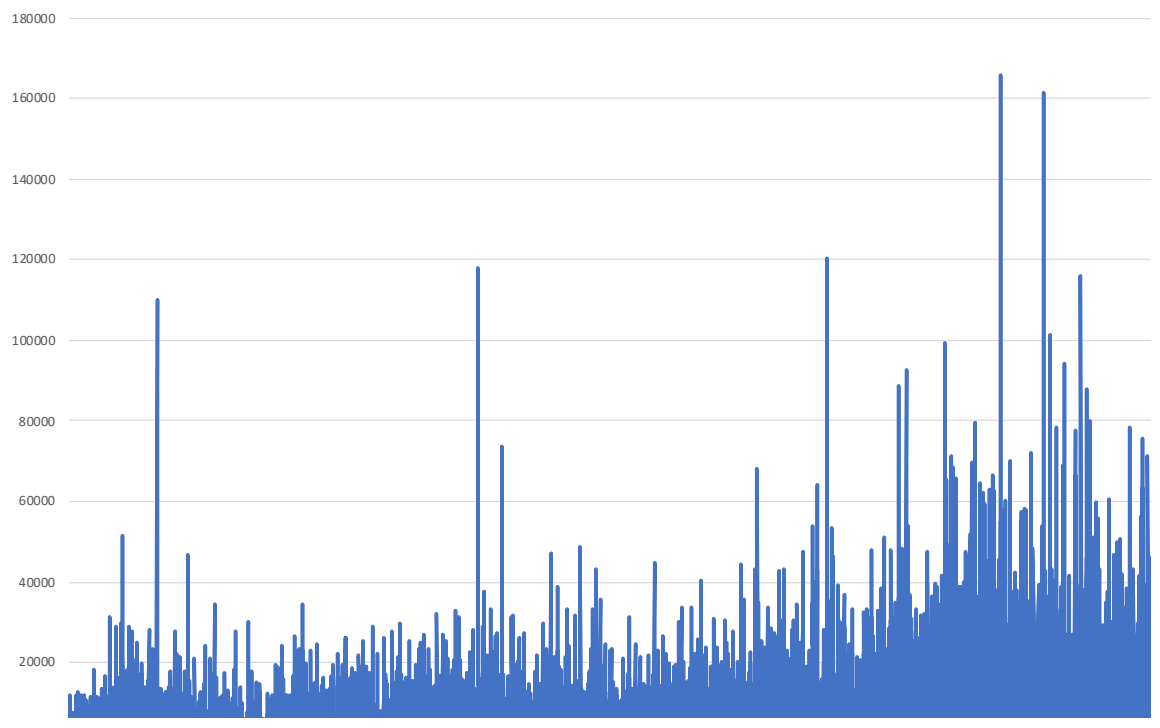

Figure 1: Length of HCA judgments (in words) from 11 November 1903 (the first judgment) to 31 August 2020 (the centenary of the Engineers Case) (inclusive).

Table 1: HCA outliers in the period from 1903-2020 (in chronological order).

\begin{tabular}{|c|}
\hline Case name and citation \\
\hline$R v$ Associated Northern Collieries (“Coal Vend Case”) (1911) 14 CLR 387 (22 December 1911) \\
\hline Bank of NSW v Commonwealth (“Bank Nationalization Case”) (1948) 76 CLR 1 (11 August 1948) \\
\hline Commonwealth v Tasmania (“Tasmanian Dam Case”) (1983) 158 CLR 1 (1 July 1983) \\
\hline Polyukhovich v Commonwealth (“War Crimes Act Case”) (1991) 172 CLR 501 (14 August 1991) \\
\hline Mabo v Queensland [No 2] (1992) 175 CLR 1 (3 June 1992) \\
\hline The Wik Peoples v Queensland (“Pastoral Leases Case”) (1996) 187 CLR 1 (23 December 1996) \\
\hline Western Australia v Ward (2002) 213 CLR 1 (8 August 2002) \\
\hline New South Wales v Commonwealth (“Work Choices Case”) (2006) 229 CLR 1 (14 November 2006) \\
\hline Thomas v Mowbray (“Jihad Jack Case”) (2007) 233 CLR 307 (2 August 2007) \\
\hline Pape v Commissioner of Taxation (2009) 238 CLR 1 (7 July 2009) \\
\hline Momcilovic v the Queen (2011) 245 CLR 1 (8 September 2011) \\
\hline Williams v Commonwealth [No1] (“School Chaplains Case”) (2012) 248 CLR 156 (20 June 2012) \\
\hline
\end{tabular}

the last outlier in 2012. In a nutshell, the incidence of these outliers has increased since the 1990s. Moreover, the most complex outliers occurred in 2002 and 2006, coinciding with increase in the occurrence frequency of these outliers. In other words, HCA judgments were becoming more complex starting from the 1990s and exhibited maximum complexity around the beginning of the new millennium.

Out of the 12 outliers identified in Table 1, 10 have constitutional law issues. The two exceptions are Coal Vend Case and Pastoral Leases Case. Based on the evidence we have so far, we can already see that when judgments are complex, it is 
likely that constitutional law issues are present. However, this article is interested in identifying a common denominator which can explain the reason for the complexity of cases shown in Table 1 above. The article will proceed by looking at each tier of outliers separately, and then by bringing findings from each tier together to identify a common denominator. The article includes in the analysis the two cases with no constitutional issues to illustrate their relevance to the other cases.

\section{FIRST TIER OUTLIERS}

The first tier has two cases. The first is Ward. ${ }^{18}$ The second is Work Choices Case. ${ }^{19}$

\section{WARD}

The case arose from an application by Ben Ward on behalf of the Miriuwung and Gajerrong People for a native title determination under the NTA. ${ }^{20}$ Some of the area brought for determination was already subject to existing pastoral leases. On 2 February 1995, the application was lodged by the Native Title Registrar for determination by the Federal Court as stipulated for under the NTA. On 24 November 1998, the primary judge, Justice Lee, found that native title exists in the determination area based on a communal "right to land." ${ }^{21}$ Before a determination by the Full Court of the Federal Court of Australia, and in reliance on an amendment of the NTA, ${ }^{22}$ the Parliament of Western Australia passed legislation ${ }^{23}$ to validate certain acts extinguishing native title. The Full Court set aside the orders of Justice Lee. On 4 August 2000, special leave was granted to appeal to the HCA. The judgment confirmed the approach taken by the Full Court of the High Court.

The four judgments in Ward deal with three areas of law: Aboriginals, appeals, and Commonwealth constitutional law. The first area relates to extinguishment of native title to land, the NTA, validity of past acts and rights in relation to land or water. The second area relates to the Federal Court of Australia, while the third relates to territories and the relationship between Commonwealth and territory laws. Chief Justice Gleeson and Justices Gaudron, Gummow and Hayne delivered one judgment. Justices McHugh, Kirby and Callinan each delivered a separate judgment.

The complexity in Ward arises from three sources. First, there is the tension between the federal and state governments as a result of the federal design in the Australian Constitution. ${ }^{24}$ This is represented by the inconsistency between state

\footnotetext{
Western Australia v Ward (2002) 213 CLR 1 (Austl.).

New South Wales v Commonwealth ("Work Choices Case") (2006) 229 CLR 1 (Austl.). Native Title Act 1993 (Cth) ("The NTA") (Austl.).

Ward v Western Australia [1998] FCA 1478 (24 November 1998) ๆๆ 258-260 (Lee J) (Austl.).

22 The Native Title Amendment Act 1998 (Cth) ("NTA") (Austl.) (assented to 27 July 1998).

23 The Titles Validation Amendment Act 1999 (WA) (Austl.).

24 For a detailed analysis of this tension, see Benjamen Franklen Gussen, Australian Constitutionalism Between Subsidiarity and Federalism, 42 Monash U. L. Rev. 383 (2016). For a comparison between Australia, the United States and Canada on the tension inherent in their respective federal constitutional designs, see Benjamen Franklen Gussen, Reflections on La Fata Morgana: Watsonian "Prestige" and Bagehotian
} 
and federal legislation. ${ }^{25}$ Second, there is the tension underlying Aboriginal rights in Australia. The case reflected the complexity of the native title concept under common law and how it can accommodate the protection of rights such as "cultural knowledge." ${ }^{26}$ The third source of complexity in Ward is the role of international law in informing domestic views on Indigenous rights, especially the International Convention on the Elimination of all Forms of Racial Discrimination. ${ }^{27}$

The constitutional issues that arose in Ward reflect the potential operational inconsistency between the NTA and the state and territory validation acts on the one hand, and the $\mathrm{RDA}^{28}$ on the other. The RDA is inconsistent with state legislation to the extent that state legislation permits transactions with land that would otherwise extinguish native title rights and interests. The RDA invalidates the state legislation to that extent. In addition, the RDA requires disregarding territory laws that impose a discriminatory burden or prohibition.

The HCA judgments in Ward suggest that the doctrine of operational inconsistency was at the heart of this case. The majority judgment discussed the inconsistency due to the operation of section 109 of the Australian Constitution, ${ }^{29}$ as well as section 122 of the Australian Constitution relating the inconsistency of territorial laws. ${ }^{30}$ In particular, section $10(1)$ of the RDA states that:

If, by reason of, or of a provision of, a law of the Commonwealth or of a State or Territory, persons of a particular race, color or national or ethnic origin do not enjoy a right that is enjoyed by persons of another race, color or national or ethnic origin, or enjoy a right to a more limited extent than persons of another race, color or national or ethnic origin, then, notwithstanding anything in that law, persons of the first-mentioned race, color or national or ethnic origin shall, by force of this section, enjoy that right to the same extent as persons of that other race, color or national or ethnic origin. ${ }^{31}$

The RDA depends upon settled principles relating to inconsistency under section 109 of the Constitution. Section 10 of the RDA ensures that persons of a particular race enjoy a right enjoyed by persons of another race, or enjoy the right to the same extent. Any state or territory legislation that impedes the exercise or enjoyment of the rights conferred by section 10 is therefore inoperative. ${ }^{32}$

For section 10 to be a valid law of the Commonwealth, it must be supported by the external affairs power (section $51[\mathrm{xxix}]$ ), given that the section cannot be

"Efficiency", 12 J. Comp. L. 80 (2017); Benjamen Franklen Gussen, On the Hardingian Renovation of Legal Transplants, in Legal Transplants in East Asia and Oceania 84 (Vito Breda ed., 2019). See also Benjamen Franklen Gussen, Axial Shift: City Subsidiarity and the World System In the 21st Century (2019).

25 Compare the Titles Validation Amendment Act 1999 (WA) (Austl.), and the Racial Discrimination Act 1975 (Cth) (Austl.).

26 Ward, 213 CLR at 84-85 (Gleeson CJ, Gaudron, Gummow \& Hayne JJ) (Austl.).

27 Id. at 388-91 (Callinan J, arguing the irrelevance of international law).

28 Racial Discrimination Act 1975 (Cth) ("RDA") (Austl.).

29 Ward, 213 CLR at 100-108 (Gleeson CJ, Gaudron, Gummow \& Hayne JJ) (Austl.).

30 Id. at 108-109, 166 (Gleeson CJ, Gaudron, Gummow \& Hayne JJ).

31 Racial Discrimination Act 1975 (Cth) s 10 (Austl.).

32 Ward, 213 CLR at 288 (Callinan J) (Austl.). 
supported by the race power in section 51(xxvi) because the RDA applies to all races. ${ }^{33}$ However, the only way the external affairs power will support section 10 is if the provision can be regarded as implementing the obligations asserted in the International Convention on the Elimination of all Forms of Racial Discrimination, ${ }^{34}$ specifically the obligations in Articles 2 and 5. ${ }^{35}$

Some commentators perceived the case to marginalize the role played by international law in native title determination:

Several of the justices also found that international law should play only a limited role in determining the rights of Australia's indigenous people. This approach has wide ramifications, demonstrated by the majority finding that there is no native title right to resources, nor a right to protect indigenous cultural knowledge. However, there are conflicting views from the Bench on the relevance of international law in this area. Justice Callinan's dissenting judgment is vociferous in rejecting any application of international law or precedent. ${ }^{36}$ Justice Kirby, however, pays particular regard to the connection between indigenous rights and international human rights. ${ }^{37}$

The complexity in Ward stems from the earlier High Court controversial decision in Pastoral Leases Case ${ }^{38}$ which will be analyzed in detail in this article under secondtier cases. A narrow majority held in Pastoral Leases Case that the rights granted by pastoral leases and native title rights were not necessarily inconsistent. Whether or not the grant of a pastoral lease extinguished native title rights depended upon the particular rights conferred by the lease and the incidents of the relevant native title. Therefore, the High Court decision was a surprise to most people, that native Australians could only be dispossessed of their land "only after a federal court had held that a native title right claimed in relation to a particular place was necessarily inconsistent with the rights of the pastoral lessee." ${ }^{39}$ Extinguishment had to proceed on case-by-case basis. The federal Parliament responded to Wik by enacting the NTA amendment ${ }^{40}$ to confine the reasoning in the Wik decision to narrow areas. The reasoning of the majority in Ward, however, demonstrates that the Wik reasoning survived in relation to pastoral and mining leases. ${ }^{41}$

Ward, 213 CLR at 279 n 819 (Callinan J) (Austl.).

34 International Convention on the Elimination of All Forms of Racial Discrimination, Mar. 7, 1966, 60 U.N.T.S. 195 [hereinafter ICERD].

35 Ward, 213 CLR at 279-80 n 819 (Callinan J) (Austl.).

36 His honor refers to Stanford v. Kentucky, 492 U.S. 361 (1989), where the United States Supreme Court rejected the use of international norms in determining the scope of the Eighth Amendment. See Ward, 213 CLR at 391 n 1086 (Callinan J) (Austl.).

37 Kate Stoeckel, Case Note: Western Australia v Ward \& Ors, 25 Sydney L. Rev. 255 (2003). See also Garth Nettheim, International Law and Native Title in Australia, 27 U. QuEENSL. L. J. 167 (2008).

38 The Wik People v Queensland ("Pastoral Leases Case") (1996) 187 CLR 1 (Austl.). See infra Part V. See the comments in Ward, 213 CLR at 67 (Gleeson CJ, Gaudron, Gummow \& Hayne JJ) (Austl.).

39 Ward, 213 CLR at 214 (McHugh J) (Austl.).

$40 \quad$ Native Title Amendment Act 1998 (Cth) (Austl.).

${ }^{41} \quad$ See Stoeckel, supra note 37. 
The majority judgment in Ward was alive to the complexity of the legal issues involved. ${ }^{42}$ The inherent complexity in Ward is said to exist in relation to the connection of Aboriginal Australians to country. This relationship, however, is a 'constituent' one. It brings to the fore the way the Australian Constitution is meant to regulate the relationship between Aboriginal rights and State and Commonwealth laws. Inevitably, the native title issue prompts analysis of specific issues under the Australian Constitution. This is confirmed by Justice Kirby's comments on the complexity of amendments to the NTA, ${ }^{43}$ and Justice Callinan's comments on the complexity of the relationship between the RDA and the NTA. ${ }^{44}$

In summary, the complexity observed in Ward reflects the uncertainty created by the earlier Pastoral Leases Case decision, ${ }^{45}$ and the constitutional validity of both Commonwealth and state legislation when the subject matter is under international law protections, such as Aboriginal (native title) rights. The comparative analysis in the case with the United States Constitution suggests that the observed complexity is related to the United States approach to Aboriginal rights and to the incorporation of international law treaties into domestic law.

The same complexity is evinced by the 2006 Work Choice Case, discussed below.

\section{WORK CHOICES CASE}

The Work Choices Case is the second case in the first-tier outliers as identified in Figure 1 above (outliers with word length over 120,000). Similar to the complexity in Ward, the complexity in Work Choices comes from three sources. First is the federal compact and the tension between federal and state legislation, this time in the area of industrial relations. Second, the industrial rights pertaining to workers. And third, the international law instruments informing the evolution of said rights in Australia.

The case, which is about a 2005 amendment to an industrial relations Act, ${ }^{46}$ arose from the Howard government attempt to have the six Australian States cede their jurisdiction over industrial relations to the Commonwealth. ${ }^{47}$ The explanatory memorandum to the amending Act explained the problem with the status quo in the following terms: ${ }^{48}$

\footnotetext{
42 Ward, 213 CLR at 93 (Gleeson CJ, Gaudron, Gummow \& Hayne JJ) (Austl.).

Ward, 213 CLR at 252 (Kirby J).

Ward, 213 CLR at 255-56 (Callinan J).

45 Even here, Justice McHugh makes a comparison with the United States Supreme Court decisions in Brown v. Bd. of Educ., 347 U.S. 483 (1954) and Brown v. Bd. of Educ., 349 U.S. 294 (1955), arguing that "[the decision in Wik] subjected the Court to unprecedented criticism and abuse, though the criticism and abuse were mild compared to that directed to the United States Supreme Court [in Brown v. Bd. of Educ.]". See Ward, 213 CLR at 213 (McHugh J) (Austl.).

46 Workplace Relations Act 1996 (Cth) (Austl.).

47 Stephen Kenner, "Work Choice": A Watershed for Australian Industrial Law or for Federation? 928 (June 6, 2007). Revised paper delivered to the 20th biennial LAWASIA Conference, Hong Kong, 5-8 June 2007, Labour Law Session, transcript available at http://forms.wairc.wa.govau/files/DiscussionPapers/Commissioner\%20Kenner\%20 -\%20Lawasia\%20Paper\%2018-4-07.pdf.

48 Explanatory Memorandum, Workplace Relations Amendment (Work Choices) Bill 2005 (Cth) 4 (Austl.).
} 
The existing system of six different industrial relations systems creates confusion for enterprises with workplaces in more than one State, resulting in compliance obligations under different industrial laws. The limitations of operating with six different systems have been recognized by numerous stakeholders and commentators from a wide political spectrum for many years.

The memorandum then cites the International Monetary Fund (IMF):49

These problems were recently noted by the International Monetary Fund, which commented:

Further reforms of industrial relations are needed to expand labor demand and facilitate productivity gains. Labor market reforms to date have substantially reduced rigidities, but centralized awards still set minimum working conditions in 20 areas through the requirement that conditions in collective and individual contracts not fall below those in awards - the no disadvantage test - and large employers face up to six different industrial relations systems at the Federal and State levels. ${ }^{50}$

The context leading to the case is as follows. In the 2004 federal election, the Howard Liberal-National Coalition (unexpectedly) won control of the Senate, which permitted the enactment of a far-ranging series of reforms to labor laws, put forward in a broad federal regime. These comprised a 2005 Act tagged as 'Work Choices', which relied heavily upon the section 51(xx) head of powerthe previous, more limited, federal regime relied upon the section 51(xxxv) head of power (industrial disputes extending beyond the limits of one State). The Act represented a "national system" in an attempt to harmonize industrial rights in Australia. And this attempt was opposed by the States. This disagreement sawed the seeds for the High Court challenge. The basis for the challenge is that the original Act was passed under the conciliation and arbitration power (section 51[xxxv] of the Australian Constitution), while the 2005 amendment ${ }^{51}$ was enacted under the corporations power (section 51[xx] of the Australian Constitution). The main issue in the case was the potential inconsistency between State and Commonwealth laws under section 109 of the Australian Constitution. ${ }^{52}$

In 2006, the Work Choices amendment was challenged in the High Court unsuccessfully by the five States and two unions. A central aspect of the 2007 election was the Australian Labor Party's promise to abolish Work Choices - which it did upon forming government.

The States of New South Wales, Western Australia, South Australia, Queensland and Victoria, and the Australian Workers' Union and the Australian Workers Unions of Employees, Queensland (AWU), and Unions NSW and others

\section{Id. at 4 .}

50 IMF, Australia: 2005 Article IV Consultation, Staff Report and Public Information Notice on the Executive Board Discussion (Aug. 24, 2005).

51 Workplace Relations Amendment (Work Choices) Act 2005 (Cth) (Austl.).

52 Tony Blackshield, New South Wales v Commonwealth, 31 MeLB. U. L. Rev. 1135 (2007). 
(Unions NSW) argued that various provisions in the industrial relations Act, ${ }^{53}$ as amended by the 2005 Act, ${ }^{54}$ were invalid. The crux of the argument was that the amendments were based on a wide interpretation of the Commonwealth corporation power, an interpretation that does not accord with the text of section 51(xx). In other words, the Commonwealth amendments were basically intended to oust the operation of state laws with respect to corporations. ${ }^{55}$

In Work Choices, by a five-to-two majority, the HCA held that the amending Act is constitutionally valid. According to the catchwords reported by the HCA, ${ }^{56}$ there is only one substantive area in this judgment: Commonwealth constitutional law. Under this area, there are 42 legal issues.

Sections 5 and 6 of the $2005 \mathrm{Act}^{57}$ sought to apply the Act to section 51(xx) corporations that employed labor, and their employees, and established minimum employment entitlements. The majority upheld the validity of the Act under the section 51(xx) power. The HCA adopted Justice Gaudron's dissent in Re Pacific Coal. ${ }^{58}$ This holding means that section 51(xx) confers on the federal Parliament a plenary (comprehensive) power with respect to those corporations that the subsection describes. The HCA rejected the argument that the corporations power was limited by the existence of the conciliation and arbitration power, or limited to relations external to any given corporation. The Court, therefore, held that the corporations power can be used to regulate the relationship between corporations and their employees. One of the objectives of the use of this power to pass the 2005 amendments was explained in the following terms:

In the Explanatory Memorandum circulated when the Workplace Relations Amendment (Work Choices) Bill 2005 was introduced, the first of the major changes to be implemented by the Bill was said to be to 'simplify the complexity inherent in the existence of six workplace relation jurisdictions in Australia by creating a national workplace relations system based on the corporations power that will apply to a majority of Australia's employers and employees'. ${ }^{59}$

The use of the corporations power was justified to harmonize workplace laws across Australia. The dominant rationale for the approach taken to the 2005 amendments was (economic) efficiency. ${ }^{60}$

In his dissent, Justice Kirby found the 2005 Act invalid because the law was clearly a law with respect to the reconciliation and arbitration (industrial disputes) power, and it would be unconstitutional to base the law on the corporations power. ${ }^{61}$

Workplace Relations Act 1996 (Cth) (Austl.).

Workplace Relations Amendment (Work Choices) Act 2005 (Cth) (Austl.).

KENNER, supra note 47, at 57.

In the AustLII Adobe/A format.

Workplace Relations Amendment (Work Choices) Act 2005 (Austl.).

58 In re Pacific Coal (2000) 203 CLR 346, 375 (Austl.). See also In re Dingjan (1995) 183

CLR 323, 365 (Gaudron J) (Austl.).

59 Work Choices Case (2006) 229 CLR 1, 68. See Explanatory Memorandum, Workplace

Relations Amendment (Work Choices) Bill 2005 (Cth) 1 (Austl.).

60 Work Choices Case, CLR at 114 (Austl.).

${ }^{61} \quad I d$. at 205-06. 
This ensures that the law comes under the scrutiny of the safeguards under the reconciliation and arbitration power: interstateness and independent resolution. ${ }^{62} \mathrm{As}$ to Justice Callinan his dissent was based on the holistic nature of the constitution, and the safeguards that the 2005 Act needs to observe. In addition, Justice Callinan argued that even if the corporations power is a valid head of power for the 2005 amendments, the power is still subject to the safeguards under section $51(\mathrm{xxxv}){ }^{63}$

Both Justice Kirby and Justice Callinan viewed the use of the corporations power as a distortion of the federal balance inherent in the Australian Constitution. ${ }^{64}$ Justice Kirby believed there is 'an implicit assertion that to give the ordinary scope to the legislative power with respect to the particular persons mentioned in section $51(\mathrm{xx})$ could or would distort [the federal] balance. ${ }^{65}$ Justice Callinan agreed:

[T] he unnuanced interpretation of the corporations power now embraced by a majority of this Court, released from the previous check stated in the industrial disputes power (and other similar constitutional checks), has the potential greatly to alter the nation's federal balance. ${ }^{66}$

The majority, however, thought that:

References to the 'federal balance' carry a misleading implication of static equilibrium, an equilibrium that is disturbed by changes in constitutional doctrine such as occurred in the Engineers' Case, and changes in circumstances as a result of the First World War. ${ }^{67}$

The explanatory memorandum for the amending bill suggests that harmonization with international law was a significant part of the rationale for the proposed "national system" under the amendment. ${ }^{68}$ The memorandum explains how the legislation gives effect to the Convention on the Elimination of all Forms of Discrimination against Women, ${ }^{69}$ the Convention concerning Discrimination in respect of Employment and Occupation, ${ }^{70}$ and the International Covenant on Economic, Social and Cultural Rights. ${ }^{71}$ The point is that the tension seen between the federal and state governments has its origins in the need for conformity with IMF recommendations and with international law obligations.

In summary, Work Choices illustrates the inherent complexity of the relationship between the Commonwealth and the States. While Ward illustrated these issues on a canvas of Aboriginal rights, Work Choice provides the same complexity with a

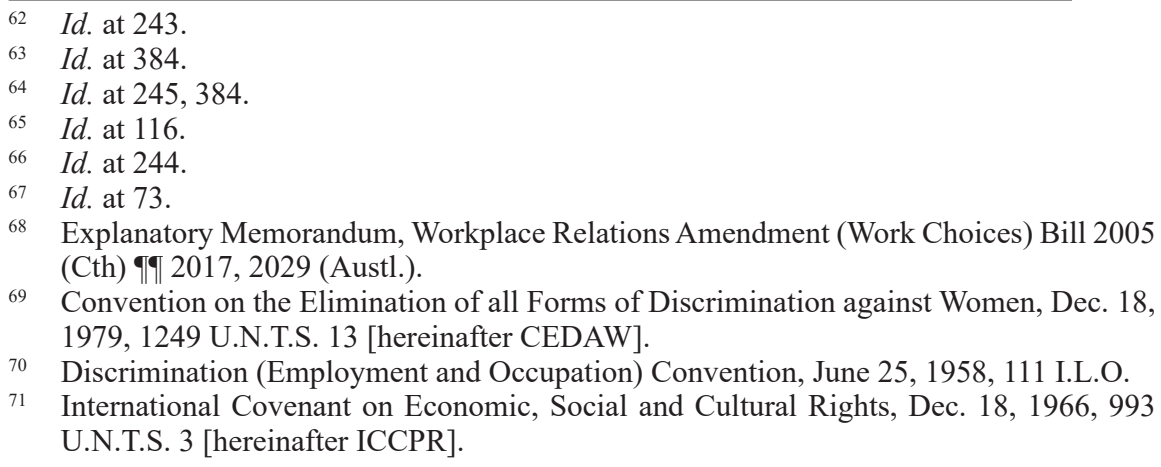


background of workers' (industrial) rights. Both cases illustrate the tension between domestic and international law under the dualist tradition that exists in Australia.

\section{SECOND TIER OUtLIERS}

Five other outliers exceeded 100,000-words in judgment, but these are significantly below the first two outliers in terms of wordcount, and hence in terms of their complexity. These outliers are Tasmanian Dam, Bank Nationalization, Momcilovic, Coal Vend, and Jihad Jack.

\section{TASMANIAN DAM CASE}

To understand the significance of this case, we need to delve deeper into its context. ${ }^{72}$ The case was decided at a time of "a changing Australian society and a changing local and international world view, including increasing concerns about the natural environment." ${ }^{\text {"73 }}$ It is a time when environmental rights were given legal expression through the concept of "world heritage", making environmental concerns more an international rather than a domestic concern. ${ }^{74}$ It is therefore understandable that the advent of this Weltanschauung created institutional conflict between the federal government and the State of Tasmania on the hand, and personal conflict that divided protestors who blocked the dam construction worksites, and the Tasmanian authorities that sought to remove these protestors. ${ }^{75}$

This historical perspective suggests the case has three types of complexity. The first is illustrated by the recurring tension brought by the protection of two sets of rights, namely environmental and Aboriginal rights. The second type is evinced by a recurring tension between vertical tiers of government. While the third complexity is elucidated by the dualist tradition in Australia, where international treaties have to be transformed into domestic law through Commonwealth legislation.

The Tasmanian Dam Case was brought about by the federal government blocking the construction of a dam in Tasmania. The context is as follows. On 22 August 1974, Australia became one of the first countries to ratify the 1972 UNESCO Convention concerning the Protection of World Cultural and Natural Heritage. ${ }^{76}$ Article 4 of the Convention states that parties to the Convention have "the duty of ensuring the identification, protection, conservation, presentation and transmission to future generations of the cultural and natural heritage ..." ${ }^{77}$ Pursuant to this duty, the Commonwealth passed legislation ${ }^{78}$ for the protection of Aboriginal archaeological sites situated within listed areas. ${ }^{79}$

\footnotetext{
72 Michael Black, The Tasmanian Dam Case: An Advocate's Memoir, 24 Griffith L. Rev. 22 (2015).

Id. at 24 .

Id. at $22,26$.

Id. at $22,24$.

76 Convention Concerning the Protection of the World Cultural and Natural Heritage, Nov. 23, 1972, 1037 U.N.T.S. 151 [hereinafter World Heritage Convention]. The USA was the first to ratify on Dec. 7, 1973. See World Heritage Convention at 152.

77 World Heritage Convention, supra note 64, art. 4.

78 World Heritage Properties Conservation Act 1983 (Cth) (Austl.).

79 Tasmanian Dam Case, 158 CLR at 65 (Austl.).
} 
In addition, Article 34 of the Convention provides:

\begin{abstract}
The following provisions shall apply to those State Parties to this Convention which have a federal or nonunitary constitutional system: (a) with regard to the provisions of this Convention, the implementation of which comes under the legal jurisdiction of the federal or central legislative power, the obligations of the federal or central government shall be the same as those for those States Parties which are not federal States: (b) with regard to the provisions of this Convention, the implementation of which comes under the legal jurisdiction of individual constituent States, countries, provinces or cantons that are not obliged by the constitutional system of the federation to take legislative measures, the federal government shall inform the competent authorities of such States, countries, provinces or cantons of the said provisions, with its recommendation for their adoption.
\end{abstract}

The following year, the Commonwealth passed further legislation ${ }^{80}$ to transform the Convention into national law. On the behest of the Tasmanian government, the Australian government made a request under the Convention for listing an area of national parks in south-western Tasmania. However, before the request was accepted in December 1982, the Tasmanian government withdrew its support for the listing, ${ }^{81}$ and passed an Act ${ }^{82}$ to authorize the construction of a dam, the Franklin Dam, over around 2 per cent of the total list area (769,355 hectares), ${ }^{83}$ and work commenced in July 1982 (only two days after the 1982 Act came into force). The dam was thought necessary to "enable the State to achieve economic growth and to increase the opportunities for employment" by generating electricity at low cost. ${ }^{84}$

In March 1983, the Commonwealth passed regulations, ${ }^{85}$ under the 1975 Act, prohibiting the construction of the Dam. In May 1983, the Commonwealth enacted further protections ${ }^{86}$ which prohibited the destruction or damage of any property that could be included in the World Heritage Listing. On 26 May 1983, the GovernorGeneral proclaimed that the 1983 Act applied to the Franklin Dam. Soon after, the Commonwealth initiated proceedings in the HCA for a declaration that the construction was illegal. The Tasmanian government cross-claimed seeking a declaration that the Commonwealth 1975 and 1983 Acts and Regulations were invalid.

In the High Court, each one of the seven HCA judges delivered a separate judgment. The justices provided different opinions as to the extent of the external affairs power, section 51(xxix), and hence the validity of the Commonwealth legislation under this head of power. ${ }^{87}$

Inter alia, in his dissenting judgment, and with whom Justices Wilson and Dawson concurred, ${ }^{88}$ Chief Justice Gibbs found the 1982 Act passed by

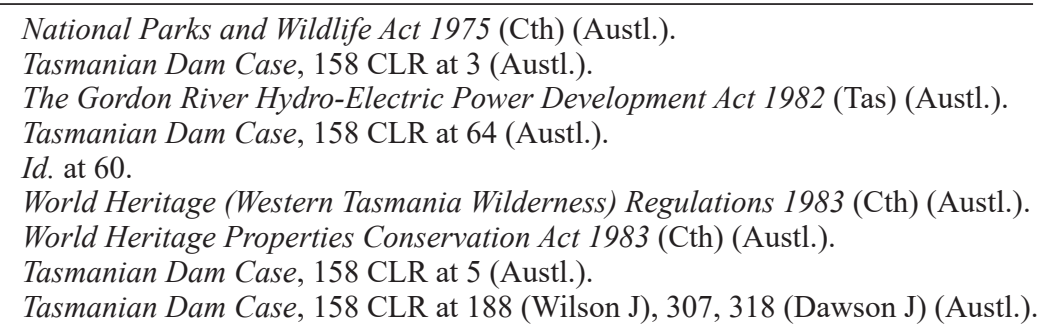


Tasmania to be valid. ${ }^{89}$ His Honor looked at whether the Convention imposes any legal obligations upon Australia. ${ }^{90}$ After consulting a number of secondary

\footnotetext{
89 Id. at 120.

90 In particular, Articles 4, 5 and 6 of the Convention. These Articles are reproduced below for completeness:
}

Article 4:

Each State Party to this Convention recognizes that the duty of ensuring the identification, protection, conservation, presentation and transmission to future generations of the cultural and natural heritage referred to in Articles 1 and 2 and situated on its territory, belongs primarily to that State. It will do all it can to this end, to the utmost of its own resources and, where appropriate, with any international assistance and cooperation, in particular, financial, artistic, scientific and technical, which it may be able to obtain.

Article 5:

To ensure that effective and active measures are taken for the protection, conservation and presentation of the cultural and natural heritage situated on its territory, each State Party to this Convention shall endeavor, in so far as possible, and as appropriate for each country:

(a) to adopt a general policy which aims to give the cultural and natural heritage a function in the life of the community and to integrate the protection of that heritage into comprehensive planning programmes;

(b) to set up within its territories, where such services do not exist, one or more services for the protection, conservation and presentation of the cultural and natural heritage with an appropriate staff and possessing the means to discharge their functions;

(c) to develop scientific and technical studies and research and to work out such operating methods as will make the State capable of counteracting the dangers that threaten its cultural or natural heritage;

(d) to take the appropriate legal, scientific, technical, administrative and financial measures necessary for the identification, protection, conservation, presentation and rehabilitation of this heritage; and

(e) to foster the establishment or development of national or regional centres for training in the protection, conservation and presentation of the cultural and natural heritage and to encourage scientific research in this field.

Article 6:

1. Whilst fully respecting the sovereignty of the States on whose territory the cultural and natural heritage mentioned in Articles 1 and 2 is situated, and without prejudice to property right provided by national legislation, the States Parties to this Convention recognize that such heritage constitutes a world heritage for whose protection it is the duty of the international community as a whole to co-operate.

2. The States Parties undertake, in accordance with the provisions of this Convention, to give their help in the identification, protection, conservation and presentation of the cultural and natural heritage referred to in paragraphs 2 and 4 of Article 11 if the States on whose territory it is situated so request.

3. Each State Party to this Convention undertakes not to take any deliberate measures which might damage directly or indirectly the cultural and natural heritage referred to in Articles 1 and 2 situated on the territory of other States Parties to this Convention. 
resources, ${ }^{91}$ the Chief Justice reached the conclusion that the Convention "imposes any legal obligation on Australia to take action to protect the Parks from possible or actual damage." 92 This is so given that "If the conduct which those articles purport to prescribe was intended to be legally enforceable, the obligations thereby created would be of the most onerous and far reaching kind." 93 Even if there were any legal obligations created by the Convention, the Chief Justice observed, then Article 34 of the Convention would mean that the legal jurisdiction for implementing the Convention is that of Tasmania, given the wholly domestic nature of the matters with which the Convention deals with. In other words, the Chief Justice found that the Commonwealth external affairs power in section 51(xxix) does not support certain sections of the Commonwealth 1975 and 1983 Acts. ${ }^{94}$ Citing legal precedents, the Chief Justice argued that the external affairs power is directed at implementing the Convention not at compliance with the Convention. ${ }^{95}$

Moreover, the Chief Justice found that these Acts also go beyond the race power in section 51(xvi), reasoning that "[a]rtefacts and relics of such antiquity are of significance to all mankind; a law for their protection is not a special law for the people of anyone race. ${ }^{96}$ Justice Wilson agreed with the Chief Justice using a similar argument. ${ }^{97}$ Justice Dawson also agreed with the Chief Justice, arguing that the laws which are contained in the 1983 Act are not special laws for the Aboriginal race, ${ }^{98}$ because "The Aboriginal sites in relation to which those prohibitions may operate are, by definition, part of the cultural or natural heritage of the nation. The laws are not laws for the protection of Aboriginal sites or artefacts or relics." ${ }^{99}$

On the other hand, the majority held that the Tasmanian Act was invalid; that Article 34(a) of the Convention imposed an obligation on the Commonwealth to implement provisions of the Convention by legislation. ${ }^{100}$ For Justice Murphy however, Article 34 was not material given that it "does not determine which organ in a federal State should discharge its obligation." 101 Justice Brennan found that Article 34 was not consistent with the constitutional law in Australia, ${ }^{102}$ and that the power to implement the Convention came under the Commonwealth. ${ }^{103}$ Justice Deane found that "Article 34 acts on the distribution of powers under the Constitution ... under [the Australian Constitution] distribution of powers, the carrying into effect of the Convention is within the paramount legal jurisdiction of the Commonwealth Parliament by virtue of the express grant of legislative power contained in section 51 (xxix)."104

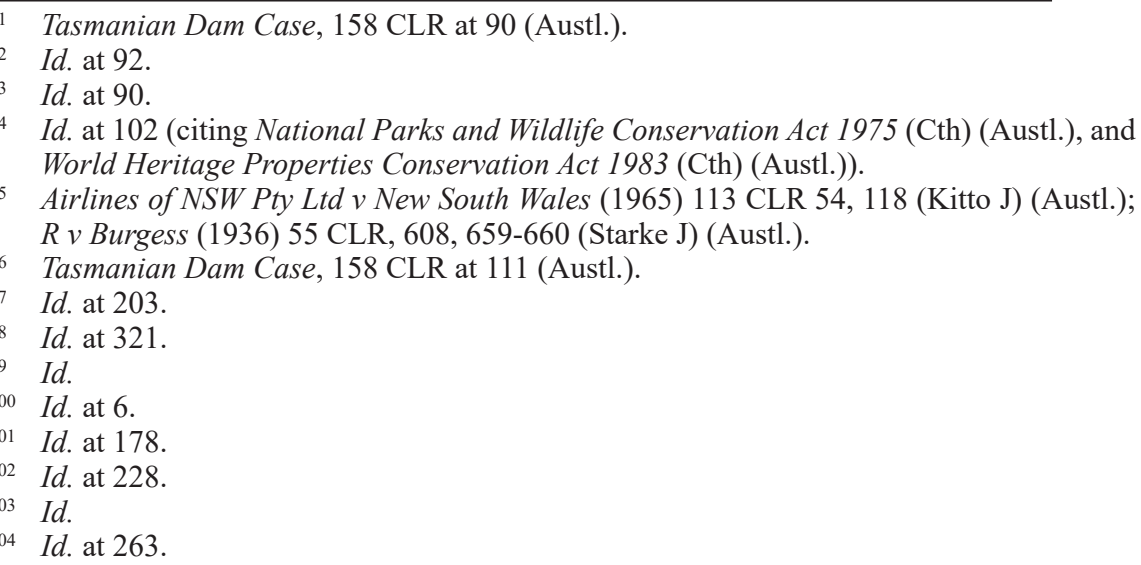


Moreover, the majority held that the protection of Aboriginal sites was within the legislative power of the Commonwealth under section 51(xxvi) of the Constitution. For Justice Mason, "A law which protects the cultural heritage of the people of the Aboriginal race constitutes a special law for the purpose of par. (xxvi) because the protection of that cultural heritage meets a special need of that people." 105 Similarly, Justice Murphy stated that "Parliament was entitled to act on the view that a law to preserve the material evidence of the history and culture of the Tasmanian Aboriginals is a law with respect to the people of the Tasmanian Aboriginal race, or with respect to the people of the Aboriginal race of Australia."106 For Justice Brennan, the race power "does not place a limitation upon the nature of the benefits which a valid law may confer, and none should be implied" 107 and "I would not construe par. (xxvi) as requiring the law to be 'special' in its terms; it suffices that it is special in its operation." 108 Justice Deane found that "subject to any general constitutional restrictions, s. 51 (xxix) of the Constitution confers upon the Commonwealth the legislative power necessary for carrying the Convention into effect including the power to make laws for procuring the performance within Australia of all or any of the obligations assumed by Australia under it."109

The HCA majority also held that the Commonwealth 1975 Act and 1983 Regulations were a valid exercise of the external affairs power (section 51(xxix)) in as far as giving effect to the Convention. Justices Mason and Murphy took a broad view of the external affairs power. Justice Mason opined that "...the notion that the subject-matter of a treaty must be of international concern remains an elusive concept" ${ }^{110}$ and found that the section 51(xxix) "confers legislative power on the Commonwealth Parliament to implement and give effect to the provisions of the Convention." 111 Justice Murphy also stated that "The [external] power extends to the execution of treaties by discharging obligations or obtaining benefits, but it is not restricted to treaty implementation", ${ }^{112}$ and that "The world's cultural and natural heritage is, of its own nature, part of Australia's external affairs." ${ }^{113}$ In other words, the "Tasmanian wilderness area is part of world heritage." 114 For Justice Brennan, "the acceptance by Australia of an obligation under the Convention suffices to establish the power of the Commonwealth to make a law to fulfil the obligation." 115 Justice Deane was also of the opinion that the race power "includes the power to make laws protecting the cultural and spiritual heritage of those people by protecting property which is of particular significance to that spiritual and cultural heritage."'116

\footnotetext{
$105 \quad I d$. at 159.

106 Id. at 181.

107 Id. at 243.

108 Id. at 245.

109 Id. at 264.

$110 \quad I d$. at 123.

$111 \quad I d$. at 136.

112 Id. at 170.

113 Id. at 172.

114 Id.

115 Id. at 219.

116 Id. at 276.
} 
The plurality (Mason, Murphy and Deane) also held the 1983 Act $^{117}$ to be a valid exercise of the external affairs power. Justices Brennan and Deane, however, considered that parts of the Act were too wide to be an appropriate implementation of the Convention. ${ }^{118}$

In summary, the case exhibits complexity sourced in tension between competing rights, especially environmental and Aboriginal rights.

\section{BANK NATIONALIZATION CASE}

The Bank Nationalization Case illustrates an analytical complexity arising from two sets of rights. First there is property rights and the "on just terms" compensation for compulsory acquisition (what is referred to in the United States as eminent domain under the Fifth Amendment "just compensation"). ${ }^{119}$ Second, there is the individual rights theory that was used in the case to explain the operation of section 92 of the Australian Constitution (free trade guarantee interstates). ${ }^{120}$ In addition to these rights, a third layer of complexity came through the vertical tension inherent in the Australian Constitution between federal and state jurisdiction.

In the Bank Nationalization Case, the Banks of New South Wales and Austalasia and some of their shareholders, and the States of Victoria, South Australia and Western Australia brought proceedings against the Commonwealth of Australia arguing that certain provisions of the Commonwealth banking Act ${ }^{121}$ were invalid. ${ }^{122}$ The objects of the Act, as stated in section 3, include "(a) the expansion of the banking business of the Commonwealth Bank as a publicly owned bank conducted in the interests of the people of Australia and not for private profit; (b) the taking over by the Commonwealth Bank of the Banking business in Australia of private banks and the acquisition on just terms of property used in that business; (c) the prohibition of the carrying on of banking business in Australia by private banks." The Act allowed for the compulsory acquisition by the Commonwealth Bank of shares in all private banks operating in Australia.

Under the Act, the Treasurer could bring compulsory acquisition under section 24 of the Act. He could then give a notice under section 13(1) and displace the original directors (section 17). Nominee directors could then be put in place (section 18) to make an agreement for compensation (under section 43 (1)) with the approval of the Treasurer. In the event that no agreement is reached, a private bank may make a claim in writing to the Commonwealth Bank for compensation

\footnotetext{
World Heritage Properties Conservation Act 1983 (Cth) (Austl.).

Id. at 5, 236, 266-67.

See Bank Nationalization Case, 76 CLR at 341 (Dixon J) (Austl.).

120 Note that the individual rights theory interpretation of s 92 lasted only until 1988 when the HCA replaced it in favor of an economic interpretation of the section. See Cole $v$ Whitfield (1988) 165 CLR 360 (Austl.). For an analysis of this interpretation, see Gonzalo Villalta Puig, Intercolonial Free Trade: The Drafting History of Section 92 of the Australian Constitution, 30 U. TAS. L. Rev. 1 (2011); Peter Connolly, Inaugural Address at the Samuel Griffith Society Proceedings in Melbourne (July 24, 1992) (transcript available at https://static1.squarespace.com/static/596ef6aec534a5c54429ed9e/t/5c95a0 71f9619a337b77329a/1553309827967/Vol1.pdf).

121 Banking Act 1947 (Cth) (Austl.).

122 Bank Nationalization Case (1948) 76 CLR 1 (Austl.).
} 
(section 43 (3)). ${ }^{123}$ In a nutshell, the Act vests the Commonwealth Bank with the function of assessing and paying compensation to the shareholders. The effect of these provisions was to enable Commonwealth Bank control over board of directors to the end of disposing any business by these banks to the Commonwealth Bank. The main legal argument by the plaintiffs was that these provisions were unconstitutional because the mechanism for determining the compensation was not "on just terms" as required under section 51(xxxi) of the Australian Constitution. ${ }^{124}$ Section 51(xxxi) of the Constitution states that:

The Parliament shall, subject to this Constitution, have power to make laws for the peace, order, and good government of the Commonwealth with respect to:

(xxxi) the acquisition of property on just terms from any State or person for any purpose in respect of which the Parliament has power to make laws;

The whole Court found the Act invalid. For the plurality, the invalidity arises from conflict with section 51(xxxi) as it fails in the provision of just terms for the acquisition of shares in private banks. ${ }^{125}$ The invalidity according to Justices Rich and Williams is because the purpose of the 1947 Act is not related to section 51(xiii) - there is lack of any legislative power authorizing the Act. ${ }^{126}$ Justice Starke

123 Id. at $175-76$.

124 The Act also gives the Federal Court of Claims an exclusive jurisdiction to decide on proceedings brought under the Act. The vesting of this exclusive jurisdiction was found by the HCA to be invalid given that the Commonwealth Bank was a person sue on behalf of the Commonwealth and therefore comes under the HCA jurisdiction in s 75(iii) of the Australian Constitution. This part of the case is less relevant to our analysis and will therefore not be covered in any detail.

125 The Bank Nationalization Case, 76 CLR at 3 (Latham CJ, Dixon \& McTiernan JJ) (Austl.).

126 Id. Note that Justices Rich and Williams were also of the opinion that the Act was inconsistent with s 105A of the Constitution. Section 105A state the following:

Agreements with respect to State debts

(1) The Commonwealth may make agreements with the States with respect to the public debts of the States, including:

(a) the taking over of such debts by the Commonwealth;

(b) the management of such debts;

(c) the payment of interest and the provision and management of sinking funds in respect of such debts;

(d) the consolidation, renewal, conversion, and redemption of such debts;

(e) the indemnification of the Commonwealth by the States in respect of debts taken over by the Commonwealth; and

(f) the borrowing of money by the States or by the Commonwealth, or by the Commonwealth for the States.

(2) The Parliament may make laws for validating any such agreement made before the commencement of this section.

(3) The Parliament may make laws for the carrying out by the parties thereto of any such agreement.

(4) Any such agreement may be varied or rescinded by the parties thereto.

(5) Every such agreement and any such variation thereof shall be binding upon the Commonwealth and the States parties thereto notwithstanding anything contained in this Constitution or the Constitution of the several States or in any 
stated that the Act is not authorized by section 51(xiii), (xxxi), (xxxix), together or separately. ${ }^{127}$

Based on precedents interpreting the meaning of "banking", Chief Justice Latham agreed with the plaintiffs' that banking is a business. ${ }^{128} \mathrm{He}$ also agreed that the federal power in section 51(xiii) is limited and is interpreted to make States "free to set up State banks" and to require the Commonwealth to "remove obstacles to the operation of such banks in other States." 129 Notwithstanding, "State law cannot prevent the Commonwealth acquiring property", ${ }^{130}$ including shares and assets in State banks. Therefore, the 1947 Act was "valid under s. 51 (xiii) of the Constitution." 131 However, the Chief Justice explained that "[a] power to acquire property from one person does not include a power to abolish the rights of creditors of that person", ${ }^{132}$ and therefore "the provisions for the discharge of the private banks from liabilities ... cannot be supported as laws made under the power to make laws for the acquisition of property: s. 51 (xxxi) of the Constitution."'133 The Chief Justice then stated that the compulsory acquisition was invalid given Commonwealth appointment of managers of property who have biding authority over the owners of the property as to the amount of compensation to be paid. ${ }^{134}$

Justices Rich and Williams delivered a joint judgment where they interpreted section 51(xiii) narrowly. ${ }^{135}$ As a result, the 1947 Act was invalid as far as not being authorized by section 51(xiii). ${ }^{136}$ It follows that no acquisition can be made under section 51(xxxi) as "property can only be acquired under this power for any purpose

law of the Parliament of the Commonwealth or of any State.

(6) The powers conferred by this section shall not be construed as being limited in any way by the provisions of section one hundred and five of this Constitution.

This argument does not relate to the tension between the federal and state governments and will not be discussed further in the analysis of this case.

The Bank Nationalization Case, 76 CLR at 3 (Austl.). The provisions are given below:

The Parliament shall, subject to this Constitution, have power to make laws

for the peace, order, and good government of the Commonwealth with respect to:

(xiii) banking, other than State banking; also State banking extending beyond the limits of the State concerned, the incorporation of banks, and the issue of paper money;

(xxxi) the acquisition of property on just terms from any State or person for any purpose in respect of which the Parliament has power to make laws;

(xxxix) matters incidental to the execution of any power vested by this Constitution in the Parliament or in either House thereof, or in the Government of the Commonwealth, or in the Federal Judicature, or in any department or officer of the Commonwealth. 
in respect of which the Commonwealth Parliament has power to make laws."137 Arguing in the alternative, Justices Rich and Williams also found the Act invalid as the mechanism for acquisition was not "on just terms" because "the power to legislate with respect to banking in its widest meaning could not justify a law placing the nominees of one bank, whether an agent of the Commonwealth or not, permanently in the management and control of the business of another bank", ${ }^{138}$ and because "to give to the Commonwealth Bank a power compulsorily to acquire shares in another bank is not a purpose in respect of which the Commonwealth Parliament has power to make laws within the meaning of s. 51(xxxi)."139

As to Justice Starke, he too observed the large and extensive nature of the acquisition power, ${ }^{140}$ however, he also found that "the power is not, in itself, wide enough to include the taking over of liability", ${ }^{141}$ although, the incidental power in section 51(xxxix) enlarges the power to warrant legislation providing the manner in which liabilities can be taken over and discharged. ${ }^{142}$ Based on his wide interpretation of the acquisition power Justice Starke found that " $[t]$ he authority to acquire shares and to take over businesses of the trading banks by agreement raises no difficulties [under the Constitution]." 143 Still, in this case, according to Justice Starke, the acquisition was not "on just terms" given that "just terms" "require that a right to interest should be given and not some merely discretionary authority to award interest."'144

As to Justice Dixon, he found the 1947 Act invalid due to the lack of authorizing power based on precedents in interpreting section 51(xiii). ${ }^{145} \mathrm{He}$ also found in the alternative that any taking under the Act is not on "just terms", ${ }^{146}$ given that "the assets of the private bank is left to the judgment of the nominees of the Commonwealth Bank ... In substance they are agents of the Commonwealth armed by statute with power to bind the company."147

Justice Dixon's judgment is best known for the individual rights theory that he used to interpret section 92 of the Australian Constitution, as a right of private banks to engage in interstate banking. Justice Dixon formulates this approach as follows:

[Section] 92 treats inter-State traffic and intercourse, not as a mere economic phenomenon, but as an activity, and as such sets it free for people to engage in. Juristically it is doubtless true that s. 92 does not confer private rights upon individuals: at all events so I decided in James $v$ The Commonwealth. ${ }^{148}$ It may perhaps also be true that its purpose is not the protection of the individual trader. But it assumes that without

137 Id.
138 Id. at 265.
139 Id.
140 Id. at 299.
141 Id.
142 Id.
143 Id. at 314.
144 Id. at 317.
145 Id. at 330.
$146 \quad$ Id. at 349.
$147 \quad$ Id. at 351.
$148 \quad$ James $v$ Commonwealth (1939) 62 CLR 339, 361-62 (Austl.). 
governmental interference trade, commerce and intercourse would be carried on by the people of Australia. across State lines, and its purpose is to disable the governments from preventing or hampering that activity. ${ }^{149}$

The last member of the bench, Justice McTiernan provided a brief judgment, where he agreed with the Chief Justice that some provisions of 1947 Act cannot be justified by any power in the Australian Constitution. ${ }^{150}$ In addition, Justice McTiernan states that in order for the acquisition to be on just terms, "independent approval of the terms of sale would be necessary."151

In summary, the Bank Nationalization Case reflects a set of complexity similar to that seen in tier one cases, barring the layer resulting from the tension between international and domestic law.

\section{MoMCILOVIC}

The third second-tier outlier is Momcilovic. ${ }^{152}$ Similar to previous cases, in addition to the vertical jurisdictional tension, Momcilovic illustrates the complexity of legal issues when they are examined in the context of protecting human rights, ${ }^{153}$ including the potential of an "invading" international law jurisprudence. ${ }^{154}$ The vertical tension in this case had two sources. First, the potential inconsistency between Victorian and Commonwealth legislation, ${ }^{155}$ which introduced a first layer of analytical complexity. Second, the added layer of potential inconsistency between the Victorian human rights Charter ${ }^{156}$ and Chapter III of the Australian Constitution. The latter tension also introduces a tension between international and domestic law, as section 32 of the Charter authorizes resort to international law instruments relevant to human rights when interpreting statutory provisions.

There are six separate judgments by Chief Justice French and Justices Gummow, Hayne, Heydon and Bell; Crennan and Kiefel writing jointly. The plethora of complex issues raised in Momcilovic was given express acknowledgement by Justice Gummow. ${ }^{157}$ The issues relate to section 5 of the Victorian Act, ${ }^{158}$ which directs juries to find guilt of the defendant unless there is evidence that the defendant did not know that drugs were in their possession. Momcilovic was sentenced under the 1981 Act on the offence of trafficking in drugs. She appealed her conviction and sentence arguing that section 5 had to be consistent with section 32 of the Charter, which requires that statutes need to be interpreted consistently with human rights. Momcilovic also argued that section 71AC of the Victorian Act, under which she was convicted for the offence of trafficking, was invalid because it imposed different penalties to trafficking offences inconsistent with the Commonwealth

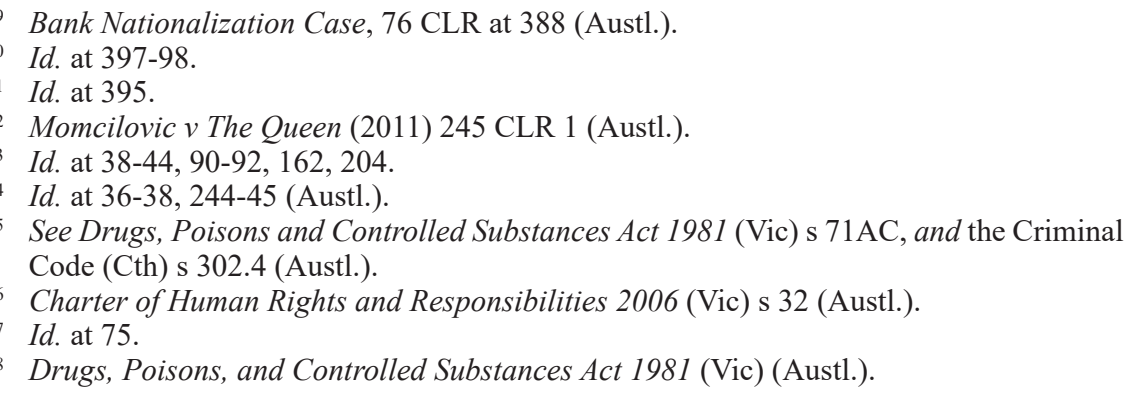


Act. ${ }^{159}$ The Crown argued that the Charter was invalid because it purports to invest the Supreme Court of Victoria with power inconsistent with the judicial function requirements of Chapter III of the Australian Constitution.

By a six-to-one majority, the Court found for Momcilovic. The HCA held that given that the prosecution in this case was brought by Victoria against Momcilovic, who at the time was resident in Queensland, this prosecution was therefore a matter under section 75(iv) of the Australian Constitution. Further, it was therefore a matter under which federal judicial power had been engaged and was exercised by Victorian courts. As to the inconsistency with Chapter III of the Constitution, the HCA stated that section 32 of the Charter did not confer powers inconsistent with Chapter III. The HCA also stated that there was no inconsistency between the Commonwealth and Victorian Acts given that the Commonwealth Criminal Code did not intend to cover the field, and did not limit the concurrent operation of the Victorian Act. ${ }^{160}$ Moreover, given that the penalty in section 71AC of the Victorian Act is less stringent than the penalty in section 302.4 of the Commonwealth Code, the provisions were not inconsistent for the purposes of section 109 of the Australian Constitution.

Of particular interest are the dicta by Chief Justice French and Justice Heydon on the role of international law in interpreting domestic law. Chief Justice French pointed to the fact that the presumption of innocence declared in section 25(1) of the Charter (A person charged with a criminal offence has the right to be presumed innocent until proved guilty according to law) ${ }^{161}$ is "expressed in terms found in Art 14(2) of the International Covenant on Civil and Political Rights (1966) (the ICCPR), Art 6(2) of the European Convention for the Protection of Human Rights and Fundamental Freedoms (1950) (the ECHR) and Art 8(2) of the American Convention on Human Rights (1969) (the ACHR)." ${ }^{\prime 162}$ Nevertheless, he also points out to the need for discrimination and care in consulting international and foreign judgments. ${ }^{163}$

In his dissentient opinion, Justice Heydon explains the relevance of international law in the following terms:

\begin{abstract}
although normally recourse to travaux préparatoires is barren and useless, the generality and obscurity of the Charter requires them to be considered, both for the present purpose and for other purposes. For example, the Attorney-General in his Second Reading Speech said:
\end{abstract}

Australia is the last major common law-based country that does not have a comprehensive human rights instrument that ensures that fundamental human rights are observed and that the corresponding obligations and responsibilities are recognized. ${ }^{164}$

As to Justices Crennan and Kiefel, they note that " $[\mathrm{t}]$ he civil and political rights identified in Pt 2 [of the Charter] are derived principally from the International

\footnotetext{
Criminal Code (Cth) s 302.4 (Austl.).

Drugs, Poisons, and Controlled Substances Act 1981 (Vic) (Austl.).

61 Charter of Human Rights and Responsibilities Act 2006 (Vic) s 25(1) (Austl.).

162 Momcilovic, 245 CLR at 37 (Austl.).

163 Id.

$164 I d$. at 154 (emphasis in the original).
} 
Covenant on Civil and Political Rights (1966) (the ICCPR)."165 They explain further that:

The ICCPR was opened for signature on 16 December 1966 and entered into force pursuant to Art 49(1) on 23 March 1976. Australia signed the ICCPR on 18 December 1972 and ratified it on 13 August 1980. The ICCPR entered into force for Australia pursuant to Art 49(2) on 13 November 1980. The text of the ICCPR appears in Sch 2 to the Australian Human Rights Commission Act 1986 (Cth) (formerly known as the Human Rights and Equal Opportunity Commission Act 1986 (Cth)). ${ }^{166}$

This mention of the ICCPR did not entail any analysis of the relationship between international and domestic law. The position under the dualist system on the implementation of international treaties is that the ICCPR has not been transformed into domestic law.

Justice Bell also makes a similar statement, ${ }^{167}$ and goes on to observe that:

The drafting conventions adopted in the two instruments differ. The ICCPR makes provision in the statement of the right for any circumstances in which the right may be limited. The Charter adopts this convention in the statement of some rights, for example, the right to privacy and the right to freedom of expression. A number of the rights which the ICCPR recognizes as being subject to limitation are set out in the Charter without reference to the circumstances of limitation. These include the right to freedom of thought, conscience, religion and belief and the right of peaceful assembly and freedom of association. However, the rights in the Charter are subject to the general limitation provision of $\mathrm{s} 7$, which is the first provision of Pt 2. ${ }^{168}$

As with the judgment by Crennan and Kiefel, Justice Bell's judgment does not offer any analysis of the tension between international law and domestic law when it comes to human rights, especially under the ICCPR.

It is useful here to explain that there is a nexus between Chapter III and international law, ${ }^{169}$ which will be discussed in more detail in War Crimes Act Case as part of third-tier outliers below. Suffice it here to reiterate the reliance on international human rights conventions such as the European Convention for the Protection of Human Rights (ECHR) and the American Convention on Human Rights, even though Australia is not party to either of these conventions. ${ }^{170}$

\footnotetext{
Id. at 202.

Id. at 203.

Id. at 244 .

Id. at 245.

169 See Kristen Walker, International Law as a Tool of Constitutional Interpretation, 28 Monash U. L. Rev. 85, 89 (2002).

170 Id. In War Crimes Act Case, Justice Deane used these conventions to support his conclusion that "ex post facto criminal legislation lies outside the proper limits of the legislative function. See Polyukhovich v Commonwealth ("War Crimes Act Case") (1991) 172 CLR 501, 611 (Austl.).
} 
In summary, the case exhibits the same complexity seen in previous cases, a tension between competing sets of rights, and the position of international vis-à-vis domestic law in protecting these rights.

\section{COAL VEND CASE}

This is the earliest case in the twelve-outlier list. It relates to convictions against a coal-vend cartel under the AIPA. ${ }^{171}$ The Act is based on the United States Sherman Act of $1890,{ }^{172}$ and was intended to protect Australian industries from predatory conduct by American companies, namely through the formation of trusts that operate against public interest. ${ }^{173}$ Justice Isaacs, sitting alone in the Hight Court, ${ }^{174}$

171 Australian Industrial Preservation Act 1906 (AIPA) (Cth) (Austl.) (assented to 24 $4^{\text {th }}$ September 1906). The full name of the Act is An Act for the Preservation of Australian Industries, and for the Repression of Destructive Monopolies.

172 Sherman Antitrust Act, 15 U.S.C. §§ 1-7 (1980).

173 The AIPA differed from the Sharman Act in a key aspect, namely the requirement for proving intent. Section 4(1)(a) of the AIPA proscribes the following conduct:

7(1) Monopolizing or attempting to monopolize or combining or conspiring to monopolize any part of trade or commerce with intent to control, to the detriment of the public, the supply or price of any service, merchandise or commodity;

In contrast, the Sharman Act $\S 2$ states that:

Every person who shall monopolize, or attempt to monopolize, or combine or conspire with any other person or persons, to monopolize any part of the trade or commerce among the several States, or with foreign nations, shall be deemed guilty of a felony, and, on conviction thereof, shall be punished by fine not exceeding $\$ 100,000,000$ if a corporation, or, if any other person, $\$ 1,000,000$, or by imprisonment not exceeding 10 years, or by both said punishments, in the discretion of the court.

(July 2, 1890, ch. 647, § 2, 26 Stat. 209; July 7, 1955, ch. 281, 69 Stat. 282; Pub. L. 93-528, § 3, Dec. 21, 1974, 88 Stat. 1708; Pub. L. 101-588, § 4(b), Nov. 16, 1990, 104 Stat. 2880; Pub. L. 108-237, title II, § 215(b), June 22, 2004, 118 Stat. 668.)

Note that s 7(1) was amended in 1910 by the Australian Industries Preservation Act 1910 (Cth) (Austl.). The amending section reads as follows:

4. Section seven of the Principal Act is amended-

(a) by omitting the words "with intent to control, to the detriment of the public, the supply or price of any service, merchandise, or commodity";

174 It is useful to point out that before sitting on the bench at the High Court, Isaacs, J. in his role as the Commonwealth Attorney-General, was responsible for introducing the AIPA. See Martin P. Shanahan \& David K. Round, Serious Cartel Conduct, Criminalization and Evidentiary Standards: Lessons from the Coal Vend Case of 1911 in Australia, 51 Bus. Hist. 875, 879 (2009). For a background on Justice Isaacs and his role as a maverick on the bench, see Zelman Cowen, Isaacs, Sir Isaac Alfred (1855-1948), 9 Australian DictionaRY BiograPhy 444 (1983). Michael Kirby, Isaac Isaacs - A Sesquicentenary Reflection at The Samuel Alexander Lecture, Wesley College Melbourne (Aug. 4, 2005) (transcript available at https://www.hcourt.govau/assets/publications/speeches/formerjustices/kirbyj/kirbyj_4aug05.pdf). 
found against the defendants. However, he did not discuss any constitutional issues, save for the power of the Commonwealth to legislate anti-trust laws. ${ }^{175}$

Justice Issacs refers only shortly to the issue of constitutional validity in relation to section 15(A) of the AIPA. The section was introduced by an amending Act in $1097 .{ }^{176}$ His honor stated that he has no doubt as to its constitutional validity. ${ }^{177}$ The case is therefore an exception to the other outliers. Those cases have constitutional issues at the heart of each case. The Coal Vend Case is instead, as discussed below, a case exhibiting a complexity arising from the interaction between legal and economic analysis.

After an extensive analysis of the evidence, and an erudite discussion of social, economic and legal issues, Justice Isaacs found intent to restraint trade. ${ }^{178}$ The next step, arguably the one more relevant to the contemporary significance of this case today, ${ }^{179}$ was to ascertain whether this restraint of trade was to the detriment of the public. ${ }^{180}$ After examining Vend's minutes, the HCA found no evidence to establish that their coordination was intended to prevent financial ruin. ${ }^{181}$ Moreover, using a 'cost-plus' approach, Justice Isaacs found the prices charged by the Vend to be unreasonable. ${ }^{182}$ However, finding detriment to the public is in essence a social question, and the analysis had to extend to understanding whether the Vend's actions result in an allocative efficiency cost that outweighed the benefits derived from increasing productive efficiency. ${ }^{183}$ Justice

175 In the appellate court, the coal miners and the shipping companies argued successfully that they did not have the requisite intent to commit a restraint of trade. In subsequent appeals the critical factor was the interpretation of price fixing and bid rigging in relation to intention. The appeal decisions are Adelaide SS Co Ltd v The King (1912) 15 CLR 65 (Austl.) and Attorney-General (Cth) v Adelaide SS Co Ltd [1913] AC 781 (PC). In 1910, and before the writs were issued, the AIPA was amended to remove the need to proving intent. However, the opportunity to amend the writs was not taken. Walker suggests by way of explanation that the then new Attorney-General had "scant regard" for the AIPA. See Geoffrey de Q. Walker, Australian Monopoly Law: Issues of Law, Fact and Policy (1967). See generally Shanahan \& Round, supra note 174.

176 The Australian Industries Preservation Act 1907 (Cth) (Austl.). Section 15(A) reads as follows:

Burden of proof

15A. In any prosecution for an offence against sections four, five, seven, eight, or nine of this Act the averments of the prosecutor contained in the information declaration or claim shall be deemed to be proved in the absence of proof to the contrary, but so that-

(a) the averment in the information of intent shall not be deemed sufficient to prove such intent, and

(b) in all proceedings for an indictable offence the guilt of the defendant must be established by evidence.

7 Coal Vend Case, 14 CLR at 404 (Austl.).

17 Id. at 649-50.

79 Shanahan \& Round, supra note 174, at n.25.

180 Coal Vend Case, 14 CLR at 469 (Austl.).

181 Id. at 518-521.

82 Id. at $547,549$.

183 The test was developed in Horner v. Graves (1831) 7 Bing 735; 131 Eng. Rep. 284. See Shanahan \& Round, supra note 174, at 890. For readers not familiar with these efficiency terms, allocative efficiency refers to the production of goods or services in accordance with consumer preferences. Productive efficiency refers to a technology 
Isaacs, finding that the cost outweighed the benefit, expressed his reasoning in the following terms:

[I]t is little satisfaction to a consumer to know that he can be the more speedily supplied with coal that he would rather not have, in return for not getting at all the coal he prefers. ${ }^{184}$

A key source of complexity in this case is the lack, at the time, of economic theories to explain the behavior of cartels. ${ }^{185}$ To his credit, in his analysis, Justice Isaacs "incorporated the ideas and methods, in a less formal way, of course, of modern microeconomic theory." ${ }^{186}$ His approach was described in the following terms:

$[\mathrm{H}]$ e created a set of criteria to be examined in search of proof that a cartel was operating ... Many of these [criteria] were not formally incorporated into economic analyses of markets until the 1950s and later ... Isaacs J was clearly several decades ahead of his time in looking at the strategic purposive and targeted behavior and dynamic effects of the actions of the Vend's members. ${ }^{187}$

In summary, the Coal Vend Case is the exception to the rule. It does not exhibit a tension between vertical levels of government, or between competing sets of rights, save probably in an economic sense, namely the rights on the supply and demand sides of the coal industry. However, Coal Vend's significance is related to how economic analysis can inform antitrust jurisprudence. Today, the significance of this case is attenuated by the amendment of the AIPA in 1910 to remove the requirement of intent.

\section{JIHAD JACK CASE}

In Jihad Jack, ${ }^{188}$ there were two areas of law: constitutional law and evidence. Under constitutional law there were 55 legal issues, and under evidence three. The judgment showcases six opinions, with Justices Gummow and Crennan writing a joint judgment.

The case arose from an interim control order sought against Joseph 'Jihad Jack' Terrence Thomas for apprehended terrorist tendencies. These control orders were introduced by a 2005 Commonwealth anti-terrorism Act, ${ }^{189}$ and became Division

constraint, where the production of one more good is impossible without sacrificing another good, unless there is an improvement in production technology. See Stephen Palmer \& David J. Torgerson, Economic Notes: Definitions of Efficiency, 318 B.M.J. 1136 (1999).

184 Coal Vend Case, 14 CLR at 485 (Austl.).

185 Shanahan \& Round, supra note 174 , at 880.

186 Id. at 893.

187 Id. at 894.

188 Thomas v Mowbray (“Jihad Jack Case”) (2007) 233 CLR 307 (Austl.).

189 Anti-Terrorism Act (No 2) 2005 (Cth) (Austl.). 
104 of the Commonwealth Criminal Code. ${ }^{190}$ The orders put restrictions on place of residence, curfews, and tracking devices. The issue in the case was whether such restrictions can be valid without a criminal conviction. Section 104.4 of the Criminal Code authorizes making an interim order if, on the balance of probabilities, the order would substantially assist in preventing a terrorist attack, or if the order is against a person who has provided training to, or received training from, a listed terrorist organization. The constitutional issue was whether the Criminal Code is invalid because it confers a non-judicial power on a federal court contrary to Chapter III of the Australian Constitution. The High Court found that section 104.4 was to be exercised judicially, given the reasonableness of standards imposed therein. The section was constitutionally valid as a protection of the Australian public under the defense power (section 51[vi]).

Thomas challenged the constitutional validity of the interim control orders against him on three grounds. First, violation of the separation of judicial powers by conferring on a federal court a non-judicial power, in contravention of Chapter III of the Australian Constitution. Second, in the alternative, if the conferred power for issuing interim control orders were a judicial power, its exercise is nonetheless contrary to Chapter III. Third, that the Commonwealth has no express or implied power to introduce these interim control orders.

A five-to-two majority (Kirby and Hayne dissenting) ${ }^{191}$ found that section 104.4 of the Criminal Code was constitutionally valid. ${ }^{192}$ Only Justice Kirby, found

190 Criminal Code Act 1995 (Cth) (Austl.). The design of div 104 borrows from the UK control order scheme which came into force in 2005. The Prevention of Terrorism Act 2005, c. 2 (UK) replaced Part IV of the Anti-Terrorism, Crime and Security Act 2001, c. $24, \S \S 21(1)$ and 23 (UK). The 2001 sections allow for the indefinite detention of aliens that are reasonably believed to be a risk to national security. The 2005 amendment came in response to the 2004 House of Lords ruling that Part IV of the 2001 Act was incompatible with the Convention for the Protection of Human Rights and Fundamental Freedoms ('European Convention on Human Rights') arts. 5,14, Nov. 4, 1950, 213 U.N.T.S. 222, and had issued a declaration to this effect under s 4 of the Human Rights Act 1998, c. 2 (UK). One key distinction between div 4 and the UK 2005 Act is that the latter requires the Secretary of State to consider, and a Control Order Review Group to subsequently monitor, whether the subject of an order could be criminally prosecuted instead (s 8). See Andrew Lynch, Thomas v. Mowbray: Australia's 'War on Terror' Reaches the High Court, 32 Melb. U. L. Rev. 1182, 1184 n.8-10 (2008).

191 Justice Hayne, however, concurred with the majority on the third ground raised by Thomas for challenging the orders.

192 Section 104.4 states:

(1) The issuing court may make an order under this section in relation to the person, but only if:

(a) the senior [Australian Federal Police] AFP member has requested it in accordance with section 104.3; and

(b) the court has received and considered such further information (if any) as the court requires; and

(c) the court is satisfied on the balance of probabilities:

(i) that making the order would substantially assist in preventing a terrorist act; or

(ii) that the person has provided training to, or received training from, a listed terrorist organization; and

(d) the court is satisfied on the balance of probabilities that each of the obligations, prohibitions and restrictions to be imposed on the person 
that the defense power under section 51(vi) of the Constitution did not support Division 104. ${ }^{193}$ His conclusion rested on the finding that Division 104 "directly encroaches upon rights and freedoms belonging to all people both by the common law of Australia and under international law." ${ }^{194}$ The other six justices found that the purposive nature of the defense power extends to protecting the Australian public against all forms of political violence, regardless of its form. ${ }^{195}$ The difference in Justice Kirby's approach rests on his interpretation of the power as is enlivened only when the threat is directed to the bodies politic, namely the Commonwealth and the States. Otherwise there is no justification to treating the threat as "beyond that of particular dangers to specific individuals or groups or interests found within the bodies politic."196

What is of more direct relevance to this article is that Justices Hayne, Callinan, and Heydon refused to consider the role of international law in the validity of the impugned provisions, especially via considering constitutional validity under the external affairs power (section 51 (xxix)) ${ }^{197}$ Three of the seven bench Court

by the order is reasonably necessary, and reasonably appropriate and adapted, for the purpose of protecting the public from a terrorist act.

(2) In determining whether each of the obligations, prohibitions and restrictions to be imposed on the person by the order is reasonably necessary, and reasonably appropriate and adapted, the court must take into account the impact of the obligation, prohibition or restriction on the person's circumstances (including the person's financial and personal circumstances).

(3) The court need not include in the order an obligation, prohibition or restriction that was sought by the senior AFP member if the court is not satisfied as mentioned in paragraph (1)(d) in respect of that obligation, prohibition or restriction.

193 Section 51(vi) of the Constitution reads as follows:

Legislative powers of the Parliament

The Parliament shall, subject to this Constitution, have power to make laws for the peace, order, and good government of the Commonwealth with respect to:

(vi) the naval and military defense of the Commonwealth and of the several

States, and the control of the forces to execute and maintain the laws of the

Commonwealth;

194 Jihad Jack Case, 233 CLR at 380, 440-42 (Austl.).

195 See in particular the theoretical analysis by Hayne J who invoked the Carl von Clausewitz theory of war. Id. at 452. See CARL VON CLAUSEWITZ, ON WAR 1-13 (James John Graham trans., N. Trübner \& Co. 1873) (1832). See also Geoffrey Lindell, The Scope of the Defense and Other Powers in the Light of Thomas v Mowbray, 10 Const. L. \& Pol'y Rev. 42, 46 (2008); David Dyzenhaus \& Raynor Thwaites, Legality and Emergency The Judiciary in a Time of Terror, in LAW AND LiberTy IN THE WAR ON TERROR 9, 23 (Andrew Lynch et al. eds., 2007).

196 Jihad Jack Case, 233 CLR at 395 (Austl.). Unlike the majority, Justice Kirby was also critical of the width of the term "terrorist act" in s 104.4 (and in s 104.1 which sets out the purpose of div 104 as the prevention of "terrorist acts"). See Jihad Jack Case, 233 CLR at 401-02 (Austl.).

197 See Lynch, supra note 190, at 1196. The section reads as follows:

Legislative powers of the Parliament

The Parliament shall, subject to this Constitution, have power to make laws for the peace, order, and good government of the Commonwealth with respect to: 
found sufficient legislative power in the external affairs power. Chief Justice Gleeson agreed with Justices Gummow and Crennan that the external affairs power supplemented any limits to the defense power "by the inclusion of governments of foreign states and expanded notions of "the public" in the definition of "terrorist act." 198 However, Justices Gummow and Crennan "did not engage at all with legal argument over whether Subdivision B was supported pursuant to treaty obligations upon the Commonwealth." 199 However, the main concern is the "conspicuous unwillingness on the part of the majority judges to adopt an overt human rights discourse in considering such measures." 200

Justice Kirby, on the other hand stated explicitly the presumption in Australia that "Australian legislation is not ordinarily taken to invade fundamental common law rights or to contravene the international law of human rights, absent a clear indication that this is the relevant legislative purpose." ${ }^{201}$

Only Justice Kirby looked at international law instruments to guide his analysis as to the validity of the impugned sections. His Honor referred to Security Council Resolutions 1373 and 1566 on the definition of terrorist acts, ${ }^{202}$ finding that Division 104 failed to have sufficient specificity to come under the external affairs power. ${ }^{203}$ In the opinion of at least one commentator: "Kirby, J makes a valid point in suggesting that the effect of domestic laws upon our standing in the international community is a flimsy hook on which to hang the validity of a law such as this. There is no clear consensus across that community as to the way in which terrorism should be rendered unlawful at the national level or even how it should be defined." 204 In finding the impugned section invalid, Justice Kirby, explaining his reasoning as follows:

Resolutions adopted by the Security Council may undoubtedly contain obligations binding on Member States, such as Australia. By virtue of Art 103 of the Charter, they assume a higher status than most other obligations owed under international law. Through its enactment under Ch VII of the Charter, and its use of mandatory language in paras 1, 2, 5, 6 and 9, Resolution 1373 was one such resolution. Clearly, it is binding on Australia as a party to the Charter but subject always, within Australia, to any relevant limitations or restrictions of the Australian Constitution.

For the purposes of s 51(xxix) of the Constitution, under which div 104 may be deemed a valid law of the Federal Parliament if it properly implements an obligation owed by Australia under international law, it is obviously necessary to keep in mind that "it is a constitution we are

(xxix) external affairs;

198 Jihad Jack Case, 233 CLR at 324-6 (Gleeson CJ), 364 (Gummow \& Crennan JJ) (Austl.).

199 Lynch, supra note 190, at 1196. See Jihad Jack Case, 233 CLR at 364-65 (Gummow \& Crennan JJ) (Austl.).

200 Paul Fairall \& Wendy Lacey, Preventive Detention and Control Orders under Federal Law: The Case for a Bill of Rights, 31 Melb. U. L. Rev. 1072, 1087 (2007).

201 Jihad Jack Case, 233 CLR at 380 (Austl.).

202 S.C. Res. 1373 (Sept. 28, 2001); S.C. Res. 1566 (Oct. 8, 2004).

203 Jihad Jack Case, 233 CLR at 409 (Austl.).

204 Lynch, supra note 190, at 1197. 
expounding." Nevertheless, the intended obligation must be characterized as one possessing "sufficient specificity" so as to attract a relevant head of the municipal legislative power. ${ }^{205}$

Citing precedents, for example the Industrial Relations Act Case, ${ }^{206}$ Justice Kirby found that the words relied upon in Resolution 1373 failed the "specificity" requirement for Division 104 to be a valid exercise of the external affairs power (section 51(xxix)). ${ }^{207}$

As to the other two grounds for challenging Division 104, namely in relation to Chapter III of the Constitution and the strict separation of the judicial power, the question to answer was whether deciding to issue a control order under Division 104 is capable of judicial determination. ${ }^{208}$ The majority answered in the affirmative, arguing that issuing such orders was reasonably necessary, and that the use of broad standards was a valid approach to applying the law. ${ }^{209}$ The minority objection was to using these broad standards in conjunction with the uncertainty inherent in the "purpose of protecting the public from a terrorist act" in section 104.4(1)(d). ${ }^{210}$

Some commentators have argued that Jihad Jack suggests the need for a bill of rights in Australia. ${ }^{211}$ Fairall and Lacy suggest that " $[\mathrm{w}]$ hat is important to highlight is that, even aside from the Chapter III issue of complying with the Boilermakers' Case, ${ }^{212}$ international human rights instruments clearly envisage different methods for the protection of human rights." ${ }^{213}$ They expound in the following terms:

Specifically, human rights conventions to which Australia is bound do not envisage a uniform role for the courts in their protection. Although the remedies for breaches of human rights are intended to be administered by the courts, different human rights require different roles for national courts in their practical operation (and thereby protection). For example, some human rights merely require the judicial oversight (that is, judicial review) of certain executive decisions. Examples under the ICCPR include arrest and detention and, potentially, the deportation of aliens ... In some circumstances, national courts are the only institutions with

205 Jihad Jack Case, 233 CLR at 407 (Austl.).

206 Industrial Relations Act Case (1996) 187 CLR 416, 486 (Austl.).

207 Jihad Jack Case, 233 CLR at 380 (Austl.).

208 Lynch, supra note 190, at 1204-05.

209 Jihad Jack Case, 233 CLR at 330-3, 334 (Gleeson CJ), 344-48, 352 (Gummow \& Crennan JJ), 507 (Callinan J) (Austl.).

210 Jihad Jack Case, 233 CLR at 417-25 (Kirby J, arguing that issuing interim control orders was not a normal part of a court's function), 468-69, 477-78 (Hayne J) (Austl.).

211 See, e.g., Fairall \& Lacey, supra note 200 [argued that the HCA treats the constitutional text as the foundation of the rule of law rather than a manifestation resting on broader foundation], Andrew Lynch \& Alexander Reilly, The Constitutional Validity of Terrorism Orders of Control and Preventative Detention 10 Flinders J. L. Reform 105 (2007) [arguing that ch III of the Constitution to be inherently contradictory in that it requires the independence of the judiciary but this independence is used by the executive to legitimatize its actions by employing the judiciary to exercise non-judicial power].

212 R v Kirby; Ex parte Boilermakers' Soc'y of Austl ("Boilermakers' Case") (1956) 94 CLR 254 (Austl.).

213 Fairall \& Lacey, supra note 200, at 1088. 
competence to authorize or carry out certain actions (such as sentencing an offender to the death penalty under art 6 of the ICCPR and declaring the lawfulness or otherwise of an arrest or detention under art 9), whereas in other instances, courts must simply retain a role in reviewing the decisions made by other competent authorities (such as decisions to separate children from their parents against their will [under the CRC]). ${ }^{214}$

They elaborate by explaining that:

What needs to occur if a more substantive approach is to be taken to the rule of law in Australian constitutional jurisprudence, is a more rigorous and transparent examination of the universally accepted human rights that are supposed to be 'fundamental' in common law jurisdictions and most Western liberal democracies. What is currently occurring in the High Court of Australia is a deliberate avoidance of the 'human rights issue' by most judges - a hangover from the conservatism of judges and driven by the politicization of the human rights debate in Australia. ${ }^{215}$

In summary, Jihad Jack illustrates the complexity of legal issues when they are examined in the context of protecting (common law) human rights, ${ }^{216}$ especially the potential of invading international law human rights. ${ }^{217}$ The complexity in the case does not involve the tension between federal and state government, but rather the separation of judicial power under the Westminster-type Australian Constitution.

\section{THIRD TIER OUTLIERS}

In the third-tier of outliers, we find the last five cases in our outlier list, namely, the Pastoral Leases case, Pape, Mabo [No 2], War Crimes Act Case, and School Chaplains Case. The rest of this section looks at each one of these cases to outline the origins of the complexity of the constitutional issues raised in each case.

\section{PAStoral Leases CASE}

In the Pastoral Leases Case, ${ }^{218}$ there was tension between two types of rights: native title or Aboriginal rights to land and rights under pastoral leases. The legal issue was whether these different rights can coexist. The Wik Peoples and the Thayorre Peoples claimed interests in land on the Cape York peninsula, located in Far North Queensland. They argued that their native title was not extinguished by the granting in 1915 and 1919 of pastoral leases over certain areas of Queensland, under Queensland legislative instruments. ${ }^{219}$ In the alternative, if the native title rights have been extinguished, they argued for damages and other relief for

214 Fairall \& Lacey, supra note 200, at 1088-89.

215 Id.

216 Jihad Jack Case, 233 CLR at 380 (Kirby J) (Austl.).

217 Id. at 440.

218 The Wik People v Queensland ("Pastoral Leases Case") (1996) 187 CLR 1 (Austl.).

219 See the Land Act 1910 (Qld) (Austl.), and the Land Act 1962 (Qld) (Aust.). 
breach of a fiduciary duty owed to them by the Crown. ${ }^{220}$ The leases contained no reservations for Aboriginal rights, instead it contained reservations to the Crown's mineral and petroleum rights and the rights of entry for third parties. In the Federal Court, Justice Drummond found that the leases granted exclusive possession to the lessees, and that the leases were not subject to any Aboriginal rights reservations. His Honor also found that leases have extinguished any native title. According to Justice Drummond, there was no breach of any fiduciary duty owed to the Wik and Thayorre people in relation to the mining leases. The plaintiffs appealed to the Full Court of the Federal Court but the matter was transferred to the HCA. ${ }^{221}$

The Pastoral Leases Case was the prequel to Ward, ${ }^{222}$ where the High Court developed a unique approach to "the interpretation of property law in Australia." 223 In fact, Ben Ward and others intervened in this case on behalf of the Miriuwung and Gajerrong Peoples, ${ }^{224}$ citing Hersch Lauterpacht's monograph on an international bill of rights to argue that "[e]xtinguishment requires the manifestation of a clear and plain intention." 225 Their intervention also made reference to United States jurisprudence suggesting that "exclusive rights to pasture or graze do not extinguish native title and [that the US jurisprudence] affirms that the fundamental question is whether there is a clear intention to extinguish." 226 However, in response, P. A. Keane, Q.C., Solicitor-General for the State of Queensland argued that the United States cases "rest on a basis fundamentally different from that in Australia. Courts there have long recognized the existence of a trust or fiduciary relationship between government and Indian tribe, akin to that of guardian and ward, founded on the Nonintercourse Act 1790 (US)", ${ }^{227}$ and that "Despite the guardian/ward

220 Pastoral Leases Case, 187 CLR at 5 (Austl.).

221 See the Judiciary Act 1903 (Cth) s 40 (Austl.).

222 The Pastoral Lease Case is the third instalment in a native title trilogy that started with Mabo v Queensland [No 2] (1992) 175 CLR 1 (Austl.), followed by Western Australia v Commonwealth (1995) 183 CLR 373 (Austl.). All four cases, including Pastoral Leases, are concerned with the doctrine of native title (also referred to sometime as the doctrine of Aboriginal title) and its extinguishment under common law and under statute. After Mabo [No 2] there was confusion as to whether the grant of lease under the Native Title Act 1993 (Cth) (Austl.) gave exclusive possession that extinguished native title. See on this point Henry Reynolds, Mabo and Pastoral Leases, 2 Aboriginal L. Bull. 8 (1992); Henry Reynolds, The Mabo Judgment in the Light of Imperial Land Policy, 16 U. N.S.W. L. J. 27 (1993); Henry Reynolds \& Jamie Dalziel, Aborigines and Pastoral Leases - Imperial and Colonial Policy 1826-1855, 19 U. N.S.W. L. J. 315 (1996).

223 Maureen Tehan, The Wik Peoples v Queensland: The Thayorre People v Queensland, 21 MeLb. U. L. Rev. 343, 352 (1997).

224 Pastoral Leases Case, 187 CLR at 30 (Austl.).

225 Id. at 31 n.120. See Gerhardy v Brown (1985) 159 CLR 70, 128 (Austl.) (quoting HersCH LAUterpacht, An InTERnATIONAL Bill of the Rights of MAN 115 (Oxford University Press 2013) (1945)).

226 Pastoral Leases Case, 187 CLR at 32 n 133 (Austl.). See Taylor Grazing Act, 43 U.S.C. $\S 315$ (2012); John S. Harbison, Hohfeld and Herefords: The Concept of Property and the Law of the Range, 22 N.M. L. Rev. 459, 470, 488-95 (1992); United States v. Dann, 706 F.2d 919, 932 (1983); United States v. Dann, 470 U.S. 39, 45 (1985). But see United States v. Dann, 873 F.3d 1189, 1196-1200 (1989), cert. denied, 493 U.S. 890 (1989).

227 Pastoral Leases Case, 187 CLR at 39 n 160 (Austl.). See Joint Tribal Council of Pasmmaquoddy Tribe v. Morton, 528 F.2d 370, 372 n.2, 374, 375-76, 379 (1975); Oneida Indian Nation v. County of Oneida, 414 U.S. 661, 684 (1974); United States v. University 
relationship, it has been recognized that Indian title can be extinguished under statute." 228

G. Griffith, Q.C., the Solicitor-General for the Commonwealth, intervening, argued that "In the United States and Canada, the grant of legally inconsistent titles extinguishes aboriginal title where aboriginal rights have not been recognized by treaty", ${ }^{229}$ and that "[i]t is accepted in the United States that power to extinguish indigenous title lay at first exclusively with the States and then with the United States, specifically Congress." ${ }^{230}$ Moreover, and more to the HCA ratio in this case, Griffith pointed out that "in the United States, the manner, time and conditions of extinguishment are nonjusticiable in the absence of a statute providing otherwise. Compensation is not required unless by treaty or statute."231

B. M. Selway, Q.C., Solicitor General for the State of South Australia, intervening, explained that the "initial recognition by Marshall, CJ of native customary law in the United States was specifically based upon the history of relations between the indigenous peoples and the settlers in the United States."232

For the purposes of analyzing the outliers, the case does not involve any constitutional law issues. It looked at native title to land under the heading "Aboriginals" and at the Queensland state government authority to make agreements. Two other issues raised in the case were the effect of mining leases on native title, and whether the Crown owed a fiduciary duty to native title holders. The majority found the mining leases to be valid, and that the Crown held no fiduciary duty to native title holders. ${ }^{233}$ Rather than extinguishment of native title, the ratio in this case seems to suggest the "subjugation or suppression" of Aboriginal rights to land for the grant of leases by the Crown on that land, ${ }^{234}$ with the actual effect decided on case-by-case basis.

of New Mexico, 731 F.2d 703 (1984), cert. denied 469 U.S. 853 (1984); Catawba Indian Tribe of South Carolina v. South Carolina, 718 F.2d 1291, 1298-99 (1983); Hoopa Valley Tribe v. Christie, 805 F.2d 874, 879 (1986); Hoopa Valley Tribe v. Christie, 812 F.2d 1097, 1102 (1987); Golden Hill Paugussett Tribe of Indians v. Weider, 39 F.3d 51, 56 (1994); Tonkawa Tribe of Oklahoma v. Richards, 75 F.3d 1039, 1045 (1996). The argument is that the fiduciary duty is not "free standing." See, e.g., United States v. Mitchell, 463 U.S. 206, 225-26 (1983). It follows therefore, according to the Solicitor-General, that said duty does not have any applicability in Australia. But see, Benjamen Franklen Gussen, The State Is the Fiduciary of the People, 3 PuB. L. 440 (2015).

228 Pastoral Leases Case, 187 CLR at 39 n 161 (Austl.). See, e.g., United States v. 7,405.3 Acres of Land in Macon, Clay, and Swain Counties, N. C., 97 F.2d 417, 422 (1938); United States v. Santa Fe Pacific Railroad Co., 314 U.S. 339, 347 (1941); cert. denied 314 U.S. 76 (1942).

229 Pastoral Leases Case, 187 CLR at $41 \mathrm{n}$ 171(Austl.). See, e.g., United States v. Atlantic Richfield Co., 435 F. Supp. 1009, 1020 (D. Alaska 1977); Missouri, Kansas and Texas Railway Co. v. Roberts, 152 U.S. 114, 117-18 (1894); Hamlet of Baker Lane v. Minister of Indian Affairs (1979), [1980] F.C. 518, 566; 107 D.L.R. 3d 513, 549 (Can.); Delgamuukw v. British Columbia (1993), 104 D.L.R. 4th 470, 525 (Can.).

230 Pastoral Leases Case, 187 CLR at 41 n 171 (Austl.). See Burtz v. Northern Pacific Railroad, 119 U.S. 55, 66 (1886); Turtle Mountain Band of Chippewa Indians v. United States, 490 F.2d 935, 945 (1974).

231 Pastoral Leases Case 187 CLR at 41.

232 Id. at $56 \mathrm{n} 248$ and 251.

233 Id. at 3 (Toohey, Gaudron, Gummow \& Kirby JJ).

234 Tehan, supra note 223, at 354. 
Siding with the plaintiffs with a four-to-three majority, the HCA decided the legal issue narrowly, by looking at the terms of each grant, and by interpreting the specific Queensland statute under which the lease had been made. ${ }^{235}$ Native title rights and pastoral rights were found capable of coexistence:

Whether there was extinguishment can only be determined by reference to
such particular rights and interests as may be asserted and established. If
inconsistency is held to exist between the rights and interests conferred by
native title and the rights conferred under the statutory grants, those rights
and interests must yield, to that extent, to the rights of the grantees. ${ }^{236}$

The case was consequently remitted to the Federal Court for a determination on the native titles claimed.

The Pastoral Lease Case decision received public disapproval, with calls to abolish native title and replace it with legislative rights similar to those in Western Australia. ${ }^{237}$ The decision that the pastoral leases in this case did not extinguish native title, and that native title could coexist with a pastoral lease led the federal Parliament to pass amendments to the NTA, ${ }^{238}$ which allowed disregarding native title when upgrading the activities that can be undertaken on pastoral leases. ${ }^{239}$ In particular, the amending Act states:

This Act also confirms that many acts done before the High Court's judgment [in Wik], that were either valid, or have been validated under the past act or intermediate period act provisions, will have extinguished native title. If the acts are previous exclusive possession acts (see section 23B), the extinguishment is complete; if the acts are previous nonexclusive possession acts (see section 23F), the extinguishment is to the extent of any inconsistency. ${ }^{240}$

The subsequent High Court decision in Ward clarified that native title can be partially or wholly extinguished when there is inconsistency between native title rights and rights granted under pastoral or mineral leases. ${ }^{241}$

In terms of the sources of complexity in this case, the tension between Aboriginal rights and lessee rights seems to be the only source. While there were comments from Justice Gummow on guidance from international law on the underpinning theories of property law, these were not given any normative weight. Justice Gummow explains the difference between radical title under international

235 Pastoral Leases Case, 187 CLR at 2 (Toohey, Gaudron, Gummow \& Kirby JJ) (Austl.). See Tehan, supra note 223, at 344.

236 Pastoral Leases Case, 187 CLR at 3 (Toohey, Gaudron, Gummow \& Kirby JJ).

237 Land (Titles and Traditional Usage) Act 1993 (WA) (Austl.). See generally Tehan, supra note 223.

238 Native Title Amendment Act 1998 (Cth) (Austl.).

239 Ward, 213 CLR at 68 (Gleeson CJ, Gaudron, Gummow \& Hayne JJ) (Austl.). See also Brian Stevenson, The Wik Decision and After (1996); Daniel Gal, An Overview of the Wik Decision 20 U. N.S.W. L. J. 488 (1997).

240 Native Title Amendment Act 1998 (Cth) s 4(6) (Austl.).

241 Ward, 213 CLR at 114 (Gleeson CJ, Gaudron, Gummow \& Hayne JJ). 
law and under British constitutional law, where the former is acquired upon assumption of sovereignty, while the latter upon settlement. However, as indicated by his honor, this distinction was simply a restatement of dicta in Mabo [No 2], ${ }^{242}$ a case that I discuss in detail below (as part of tier-three outliers).

What is surprising about Pastoral Leases Case is that it flouted the "international moral code that prohibited racial discrimination", which Mabo [No 2] was careful to follow, although eventually defeated by the federal government response as illustrated above. ${ }^{243}$ In essence, "the indigenous land rights debate in Australia is an example of, in Turner and Rojeck's (2001: 127) terms, 'the frequent tension between national systems of rights and international human rights." 244 What is at the heart of the case is therefore a marginalization of international law that is intended, it seems, to prevent the following eventuality:

\begin{abstract}
When concerned with an internal colonial situation, the question should not be how can we deal with indigenous 'claims' against the state, but rather how can the colonizers legitimately settle and establish their own sovereignty (Tully, 2000: 52). Tully (2000: 53) suggests that for the settler state to gain legitimacy in this regard it is necessary to hold negotiations with indigenous peoples on a 'nation' to 'nation' basis. Indigenous peoples would be 'recognized' as nations equal in status to the settler state and consequently the ensuing treaties would be 'international treaties'. Under this model, the indigenous nation in question has the right to appeal not only to domestic courts for redress of infringement, but, if this fails, to international law, like any other nation (Tully, 2000). Tully argues that such negotiations have the potential to resolve the problem of internal colonization, and describes the approach as a form of treaty federalism. ${ }^{245}$
\end{abstract}

In summary, Pastoral Leases Case is an example of a constitutional case that was decided outside any constitutional analysis, given the marginalization of international law in Australia. The case is part of a trilogy of outliers, which includes Ward (from the first-tier) and Mabo [No 2] (from the third-tier). The case is in essence "a prime example of the tension between national rights regimes and international human rights norms." 246

242 Mabo [No 2], 175 CLR at 86-87 (Austl.).

243 Damien Short, The Social Construction of Indigenous 'Native Title' Land Rights in Australia, 55 Current Soc. 857, 873 (2007).

244 Id. at 857, 859. See Bryan S. Turner \& Chris Rojek, Society and Culture: Principles OF SCARCITY AND SOLIDARITY (2001).

245 Short, supra note 243 at 872 (citing James Tully, The Struggles of Indigenous Peoples for and of Freedom, in Political Theory and the Rights of Indigenous Peoples 36 (Duncan Iverson et al. eds., 2000).

246 Id. See also Robert French, Protecting Human Rights Without a Bill of Rights, $43 \mathrm{~J}$. Marshall L. Rev. 769 (2010); Darryl Cronin, Trapped by History: Democracy, Human Rights and Justice for Indigenous People in Australia, 23 Austl. J. Hum. RTs. 220 (2017); Scott A. Reid et al., Aboriginal Self-Determination in Australia: The Effects of Minority-Majority Frames and Target Universalism on Majority Collective Guilt and Compensation Attitudes, 31 Hum. Comm. Res. 189 (2005). 


\section{PAPE}

The complexity presented by the case has its origins in the multiple powers raised as giving authority to the Commonwealth to legislate the impugned Act. However, unlike the other outliers, in Pape there is no tension between vertical levels of government, nor a tension between competing sets of rights. Although the relevance of a tension between domestic and international law can be seen in the defendants' argument that the Act is supported by the external affairs power (section 51(xxix)), both as a response to the 2008 Global Financial Crisis (GFC), and due to "the effect the law may have internationally." 247

In the aftermath of the GFC, the Australian Labor Party's Kevin Rudd Government looked at mitigating economic downturn by, inter alia, passing taxbonus legislation. ${ }^{248}$ The Act's explanatory memorandum refers to "the most significant economic crisis since the Second World War" and explained the rationale for the Act as to "provide immediate economic stimulus to boost demand and support jobs." ${ }^{249}$ Section 5(1) of the Act provided a tax bonus for any taxpayer earning less than AUD \$100,000 for the financial year ending 30 June 2008.

Bryan Reginald Pape was a law lecturer at the University of New England, Armidale, New South Wales, a barrister, and a former officer of the National Party of Australia. He was entitled to receive a putative tax bonus of AUD $\$ 250,{ }^{250}$ as part of an AUD \$10.4 billion package. ${ }^{251}$ However, Pape decided to challenge the Act arguing that the payments were not a tax bonus but a gift, and therefore not supported by the taxation power, or any other head of power, in the Australian Constitution (section 51(ii)). The Commonwealth argued that the Act is authorized by a combination of powers: section 81 appropriations, ${ }^{252}$ section 51(ii) taxation power, section 51(i) trade and commerce power, ${ }^{253}$ and the nationhood power. ${ }^{254}$

247 Pape, 238 CLR at 14 (Austl.).

248 Tax Bonus for Working Australians Act (No 2) 2009 (Cth) (Austl.). See Andrew McLeod, The Executive and Financial Powers of the Commonwealth: Pape v Commissioner of Taxation, 32 Sydney L. Rev. 123 (2010); Duncan Kerr, Pape v Commissioner of Taxation: Fresh Fields for Federalism?, 9 QUT L. Rev. 311 (2009).

249 Pape, 238 CLR at 2 (Austl.).

$250 \quad I d$. at 3.

251 Id. at 30.

252 Section 81 reads as follows:

Consolidated Revenue Fund:

All revenues or moneys raised or received by the Executive Government of the Commonwealth shall form one Consolidated Revenue Fund, to be appropriated for the purposes of the Commonwealth in the manner and subject to the charges and liabilities imposed by this Constitution.

253 Sections 51(i) and 51(ii) read as follows:

Legislative powers of the Parliament:

The Parliament shall, subject to this Constitution, have power to make laws for the peace, order, and good government of the Commonwealth with respect to:

(i) trade and commerce with other countries, and among the States;

(ii) taxation; but so as not to discriminate between States or parts of States;

254 The nationhood power was first discussed in Victoria $v$ Commonwealth and Hayden ("AAP Case") (1975) 134 CLR 338 (Austl.). The power was said to be appropriate to the executive government of a nation, and is more general than the constitutional, legislated, 
The main legal issue in this case was constitutional, and in particular, powers of the Commonwealth Parliament.

Per curiam the HCA found that sections 81 and 83 are not powers, and therefore could not on their own authorize Commonwealth spending. ${ }^{255}$ By a majority of fourto-three, the HCA found the Act to be valid enactment, incidental (under section 51 (xxxix) $)^{256}$ to the exercise of nationhood power. ${ }^{257}$ A minority (Hayne and Kiefel) also found the Act valid under the taxation power (section 51(ii)).

In rejecting the external affairs argument, Justice Heydon explained it in the following terms:

The defendants joined South Australia in advancing this submission. They said that the G-20 Declaration was an agreement — not an agreement "made within any formal treaty structure" and not "an enforceable agreement", but rather a "commitment to act in a particular way for international purposes". But the defendants did not go so far as to submit that those G-20 countries which had not complied with the commitment were departing from any agreement. The defendants also submitted that s 51(xxix) extended to implementing recommendations of international bodies that are not binding under international law. They relied on certain "recommendations" as steps carried out in the implementation of the G-20 Declaration.

or prerogative powers of the Commonwealth. In Davis $v$ The Commonwealth (1988) 166 CLR 79 (Austl.), the HCA found that Commonwealth appropriations celebrating the Australian bicentenary were authorized by the implied nationhood power. The nationhood power formed part of the constitutional analysis in both Pape and in School Chaplains Case, which is also one of the third-tier outliers.

255 Pape, 238 CLR at 3 (Austl.). Section 83 reads as follows:

Money to be appropriated by law:

No money shall be drawn from the Treasury of the Commonwealth except under appropriation made by law.

But until the expiration of one month after the first meeting of the Parliament the Governor-General in Council may draw from the Treasury and expend such moneys as may be necessary for the maintenance of any department transferred to the Commonwealth and for the holding of the first elections for the Parliament.

256 Section 51(xxxix) reads as follows:

Legislative powers of the Parliament:

The Parliament shall, subject to this Constitution, have power to make laws for the peace, order, and good government of the Commonwealth with respect to:

(xxxix) matters incidental to the execution of any power vested by this Constitution in the Parliament or in either House thereof, or in the Government of the Commonwealth, or in the Federal Judicature, or in any department or officer of the Commonwealth.

257 Pape, 238 CLR at 3. Note that Pape refers to Polyukhovich v The Commonwealth ("The Wartimes Act Case") (1991) 172 CLR 501 (Austl.) in support of the proposition that the s 5(xxix) second argument, namely the international effect of the Act, is "too broad an expression of the scope of the power" (Pape, 238 CLR at 3 (Austl.)). I will discuss The Wartimes Act Case in some more detail later in this section. 
In explaining his reasoning, Justice Heydon stated that it is "highly improbable that in the ordinary course the deliberations of such a body would generate obligations in international law." ${ }^{258} \mathrm{He}$ referred to The Industrial Relations Act Case ${ }^{259}$ where it was said that an "external affair" did not exist where all that was stated was a "broad objective with little precise content and permitting widely divergent policies by parties", ${ }^{260}$ and suggests that "[y]et that is all the G-20 Declaration does."261

On the other hand, in accepting the argument, Chief Justice French explained that the bodies that tackled the economic implications on the international stage extended to more than the Group of 20 (G20). It also included the International Monetary Fund (IMF), and the Organization for Economic Cooperation and Development (OECD) ${ }^{262}$ His Honor explained the obligation that members of the IMF and the OECD, which include Australia, have to assume. ${ }^{263} \mathrm{He}$ then goes on to state that:

A statement from an IMF-OECD-World Bank seminar convened in February 2009 included the following:

In parallel, there continues to be an urgent need for fiscal stimulus. The size and composition of fiscal packages should be consistent with each country's fiscal space and institutional capacity. The deepening of the downturn suggests the need for an increase in high-impact fiscal expenditures in the first half of 2009, with further support in the following quarters, by countries in a position to prudently undertake such spending. At the same time, embedding stimulus packages in a credible mediumterm strategy that safeguards fiscal sustainability will also increase their impact in the short term. ${ }^{264}$

Chief Justice French then explains how the Updated Economic and Fiscal Outlook (the UEFO), published by the Australian Treasurer and the Minister for Finance on 3 February 2009, refers to the statements by these international institutions about the necessity for domestic fiscal stimulus. ${ }^{265}$

In their joint judgment, Justices Gummow, Crennan and Bell also referred to the UEFO, ${ }^{266}$ stating that "Reports and statements provided by international bodies, the Group of Twenty and the International Monetary Fund, emphasize the global nature of the current financial and economic crisis. $" 267$

258 Pape, 238 CLR at 159,163 (Austl.).

259 Victoria $v$ The Commonwealth ("Industrial Relations Act Case") (1996) 187 CLR 416, 486 (Austl.).

260 Pape, 238 CLR at 163 n 607 (citing Victoria v The Commonwealth (1996) 187 CLR 416, 486 (Brennan CJ, Toohey, Gaudron, McHugh \& Gummow JJ)) (Austl.).

261 Pape, 238 CLR at 163 (Austl.).

262 Id. at 25. The OECD being the Convention on the Organization for Economic Cooperation and Development made in Paris in 1960, to which Australia became a member in 7 June 1971.

263 Pape, 238 CLR at 26 (Austl.).

264 Id. at 29.

$265 I d$. at 29.

266 Id. at 88 .

267 Id. 
Justices Hayne and Kiefel, however, were of the view that the Commonwealth "was given no express head of power with respect to [creating and fostering national markets]" 268 and that "the expression 'national economy' is anything but certain", ${ }^{269}$ adding that "Australia's economic wellbeing is not isolated from global economic influences. That may suggest that there is only limited utility in treating (or at least in continuing to treat) the Australian national economy as if it is a separate and distinct unit." 270 They went on to state that "[i]t is sufficient to observe that neither the Declaration by the leaders of the G-20, nor the recommendations of either the IMF or the OECD, imposed any obligation on Australia to take action of the kind now in question", ${ }^{271}$ that the "recommendations made by the IMF and the OECD are of ... [an] advisory or hortatory character."272

In summary, Pape illustrates tension between international law and domestic law during a global economic crisis, and how a short-term government intervention, namely the introduction of an economic stimulus package, was challenged for lack of constitutional authority to so legislate.

\section{3. $\mathrm{MABO}[\mathrm{No} 2]$}

In 1879 Queensland annexed islands in the Torres Strait, between the Cape York peninsula, in Queensland's far north, and the south east coast of Papua New Guinea. In 1982 Eddie Mabo, David Passi and James Rice, members of the Meriam people who occupied the Murray Islands in Torres Strait, sought a declaration that they retained their land rights to these islands, claiming Crown's sovereignty over the Islands was subject to Meriam people based upon local custom and traditional native title. In 1985, the Queensland government passed legislation ${ }^{273}$ to extinguish any Aboriginal land rights in these Islands.

In Mabo [No 1], ${ }^{274}$ Mabo and the other plaintiffs sought a demurrer to prevent the Queensland government from relying on the 1985 Act in their defense in the main case, which came to be known as Mabo [No 2]. ${ }^{275}$ The proceedings in the first case challenged the validity of the Queensland Act, arguing that it was inconsistent with the protection of the rights to own property and not to be arbitrarily deprived of property under the RDA. ${ }^{276}$ These rights mirror the civil rights in Article 5(d) of the ICERD. ${ }^{277}$ The parties agreed that the first case should proceed on the assumption that the Meriam people hold native title rights in the islands, although the question had to be decided in the second case.

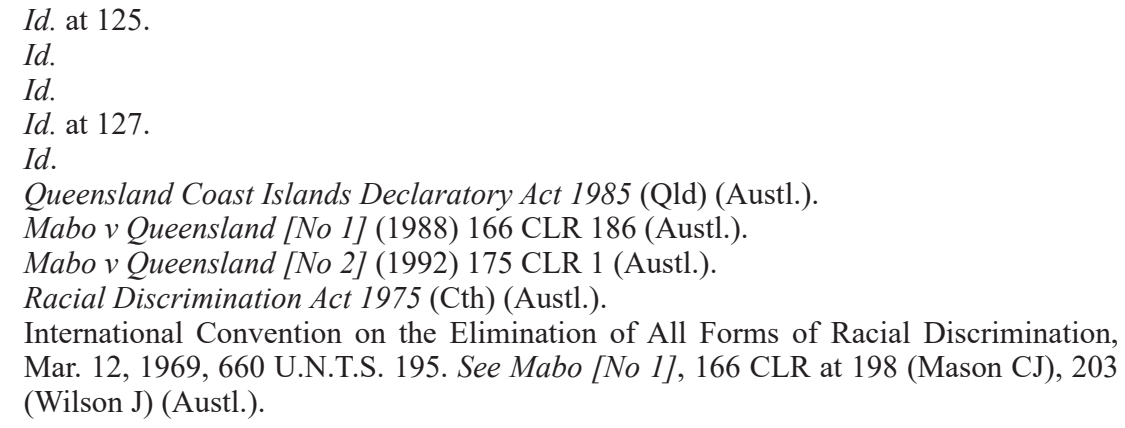


A four-to-three majority accepted this inconsistency argument. The plurality stated that:

By extinguishing the traditional legal rights characteristically vested in the Miriam people, the 1985 Act abrogated the immunity of the Miriam people from arbitrary deprivation of their legal rights in and over the Murray Islands. The Act thus impaired their human rights while leaving unimpaired the corresponding human rights of those whose rights in and over the Murray Islands did not take their origin from the laws and customs of the Miriam people. If we accord to the traditional rights of the Miriam people the status of recognized legal rights under Queensland law (as we must in conformity with the assumption earlier made), the 1985 Act has the effect of precluding the Miriam people from enjoying some, if not all, of their legal rights in and over the Murray Islands while leaving all other persons unaffected in the enjoyment of their legal rights in and over the Murray Islands. Accordingly, the Miriam people enjoy their human right of the ownership and inheritance of property to a "more limited" extent than others who enjoy the same human right. ${ }^{278}$

Justice Deane delivered a separate judgment where accepted the inconsistency argument based on the operation of the 1975 Act, ${ }^{279}$ stating that "[i]n the context of the nature of the rights which it protects and of the provisions of the International Convention which it exists to implement, the section is to be construed as concerned not merely with matters of form but with matters of substance, that is to say, with the practical operation and effect of an impugned law."280

The minority (Mason, Wilson and Dawson), however, though that the ICERD was of no assistance to the plaintiffs. For Chief Justice Mason, this is so because "the precise nature and extent of the rights and interests asserted by the plaintiffs" was not clear. ${ }^{281}$ For Justice Wilson, the ICERD was of no assistance given that its operation was directed to special measures not envisaged in the 1975 Act. $^{282}$ Justice Dawson was of a view similar to that of Justice Wilson. ${ }^{283}$

In the second case, Mabo [No 2], now that Queensland could not rely on the 1985 declaratory Act, the HCA needed to decide whether the Miriam people have native title to the Torres Strait Islands. A six-to-one majority (Justice Dawson

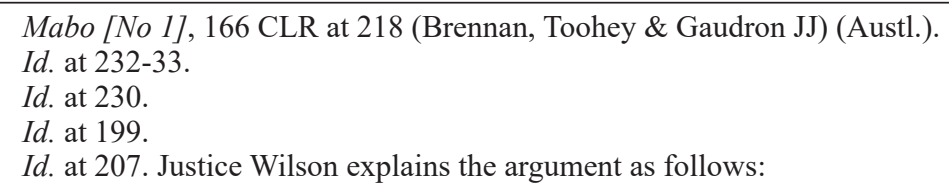

Let it be supposed that the Queensland legislature passed a law which expressly recognized and entrenched the traditional rights claimed by the plaintiffs ... The recognition, enjoyment or exercise of the right, on an equal footing, would be impaired because the law would secure to the plaintiffs an entrenched and enlarged right to inherit compared with that enjoyed by other racial groups in Queensland. Underlying their special right would be the rights accorded to all Queenslanders by the general inheritance laws. Of course, in the circumstances I have postulated, the law would probably be upheld as a special measure within the meaning of Art. 1(4) of the Convention ... .

Id. at 242. 
dissenting) held that native title to land survived Crown's acquisition of sovereignty and radical title in the islands, ${ }^{284}$ although Crown's sovereignty exposed native title to extinguishment by "a valid exercise of sovereign power inconsistent with the continued right to enjoy native title." ${ }^{285}$ The main difference between the majority judgments in Mabo [No 1] and Mabo [No 2] was stated by Chief Justice Mason and Justice McHugh in Mabo [No 2] in the following terms:

The main difference between those members of the Court who constitute the majority is that, subject to the operation of the Racial Discrimination Act 1975 (Cth), neither of us nor Brennan J agrees with the conclusion to be drawn from the judgments of Deane, Toohey and Gaudron JJ. that, at least in the absence of clear and unambiguous statutory provision to the contrary, extinguishment of native title by the Crown by inconsistent grant is wrongful and gives rise to a claim for compensatory damages. ${ }^{286}$

Justice Brennan was clear on the interaction between international and common law in Australia. He points out that "Although the manner in which a sovereign state might acquire new territory is a matter for international law, the common law has had to march in step with international law in order to provide the body of law to apply in a territory newly acquired by the Crown. ${ }^{287}$ His honor then explained the three relevant mechanisms recognized in international law as effective for acquiring sovereignty, namely, "conquest, cession, and occupation of territory that was terra nullius." ${ }^{288}$ Sovereignty in Australia had to be acquired through an enlarged doctrine of terra nullius to overcome the existence of Aboriginal peoples across the continent. ${ }^{289}$ His honor then proceeded to explain the then recent decision by the International Court of Justice (ICJ) in its Advisory Opinion on Western Sahara, ${ }^{290}$ where the ICJ states that "territories inhabited by tribes or peoples having a social and political organization were not regarded as terrae nullius", ${ }^{291}$ and that "the concept of terra nullius, employed at all periods, to the brink of the twentieth century, to justify conquest and colonization, stands condemned", ${ }^{292}$

284 Mabo [No 2], 175 CLR at 2, 15 (Austl.).

285 Id. at 3.

286 Id. at 15.

287 Id. at 32.

$288 I d$. at 32 n. 65 (citing E. Evatt, The Acquisition of Territory in Australia and New Zealand, in Grotian Society Papers 16 (C. H. Alexandrowicz ed., 1968), who mentions only cession and occupation as relevant to the Australasian colonies).

289 Mabo [No 2], 175 CLR at 36 (Austl.). For a detailed analysis of the expanded terra nullius, see Gerry Simpson, Mabo, International Law, Terra Nullius and the Stories of Settlement: An Unresolved Jurisprudence, 19 MeLb. U. L. Rev. 195 (1993). See also Gurdial Singh Nijar, Traditional Knowledge Systems, International Law and National Challenges: Marginalization or Emancipation?, 24 EuR. J. INT'L. L. 1205 (2013) (argues the importance of the UN Declaration of the Rights of Indigenous Peoples (UNDRIP) and the Convention on Biological Diversity (CBD) for the protection of First Nations); Kristen Walker, supra note 167 (argues as controversial Justice Kirby's use of international law to interpret the Australian Constitution).

290 Western Sahara, Advisory Opinion, 1975 I.C.J. 12 (Oct. 16).

291 Id. at 39.

292 Id. at 86. 
made it imperative that "the common law should neither be nor be seen to be frozen in an age of racial discrimination", ${ }^{293}$ and that "[t]he opening up of international remedies to individuals pursuant to Australia's accession to the Optional Protocol to the International Covenant on Civil and Political Rights brings to bear on the common law the powerful influence of the Covenant and the international standards it imports. ${ }^{294}$ Importantly, Justice Brennan stated that:

The common law does not necessarily conform with international law, but international law is a legitimate and important influence on the development of the common law, especially when international law declares the existence of universal human rights. ${ }^{295}$

It followed, therefore, that when a common law doctrine such as terra nullius loses its legitimacy under international law, it also loses its legitimacy under common law.

On the other hand, Justices Deane and Gaudron delivering one opinion, suggested that the settlement of Australian colonies was an exercise of the Crown's prerogative power to "extend its sovereignty and jurisdiction to territory over which it had not previously claimed or exercised sovereignty", ${ }^{296}$ and hence rejecting the relevance of international law in the case. Similarly, Justice Toohey adopted a distinction between sovereignty and title to land, ${ }^{297}$ although he also referred with approval to the Western Sahara advisory opinion. ${ }^{298}$

Justice Dawson, dissenting, was less inclined to deal with the relevance of international law generally, and in particular, the tension between international law and domestic (common) law, namely on the doctrine of terra nullius.

In summary, the High Court decided that to deny indigenous rights to land would be "unjust and contrary to contemporary international human rights standards, especially the principle of racial equality." ${ }^{299}$ The complexity in Mabo [No 2] flows from the need for domestic law to stay in step with international law-a source of complexity that we have already seen in other outliers.

\section{WAR CRIMES ACT CASE}

The significance of this case as part of the twelve outliers lies in the High Court wrestling with the problems of determining the status of customary international law in Australia. The High Court accepted the proposition that a widely accepted norm or custom of international law "will be more readily regarded as part of Australian law. Overall, however, the High Court adopted what international lawyers like to term a 'dualist' approach, which regards national and international legal systems as quite separate." 300

\footnotetext{
Mabo [No 2], 175 CLR at 42 (Austl.).

Id. at 42 .

$I d$.

Id. at 78 .

Id. at 180 .

Id. at 181.

9 Short, supra note 241 , at 858.

300 Charlesworth, supra note 9, at 5.
} 
In the War Crimes Act Case, Ivan Timofeyevich Polyukhovich, a UkrainianAustralian born in today's Belarus, was charged of an indictable offence under a 1945 Commonwealth Act $^{301}$ for war crimes committed in the Ukraine, while under German occupation, between 1942 and 1943. It was alleged that he willfully killed a number of people under German policies persecuting the Jewish people, partisans or communists. The plaintiff was not then an Australian citizen or resident. ${ }^{302}$ In 1988, the 1945 Act was almost entirely repealed and replaced. ${ }^{303}$ The amending Act visits the crimes indictable under the 1945 Act with the application of the 1949 Geneva Conventions defining "war crimes." 304 Polyukhovich argued that the 1945 Act was invalid on three grounds. It was beyond the scope of the external affairs (section 51(xxix)) and defense (section 51(vi)) powers, and because it was a usurpation of Chapter III judicial power in that the Act was effectively a bill of attainder. ${ }^{305}$

A six-to-one majority held that the 1945 Act was a valid exercise of the external affairs power (section 51(xxix)) to the extent that it operated on conduct outside Australia, making that conduct a criminal offence. ${ }^{306}$ Chief Justice Mason, after canvassing most recent Australian constitutional precedents at the time, based his reasoning on the point that given the Act was "undertaken by way of implementation of an international Convention [Geneva Conventions I-IV]", 307 it follows that "it is not necessary that the Court should be satisfied that Australia has an interest or concern in the subject-matter of the legislation in order that its validity be sustained. It is enough that Parliament's judgment is that Australia has an interest or concern." ${ }^{308}$

Given that his honor found the Act to be valid under the external affairs power, Chief Justice Mason did not entertain the second ground as to invalidity under the defense power.

As to the third ground for the invalidity of the 1945 Act, and after canvassing relevant Australian case law on the definition of "judicial power", his honor stated that " $[\mathrm{t}]$ here is nothing in the statements which I have quoted to suggest that an exercise of judicial power necessarily involves the application to the facts of a legal

$301 \quad$ War Crimes Act 1945 (Cth) (Austl.).

302 War Crimes Act Case, 172 CLR at 548 (Austl.).

303 War Crimes Amendment Act 1988 (Cth) (Austl.).

304 See Convention for the Amelioration of the Condition of the Wounded and Sick in Armed Forces in the Field (Geneva Convention No. I), Aug. 12, 1949, 75 U.N.T.S. 31; Convention for the Amelioration of the Condition of the Wounded, Sick, and Shipwrecked Members of Armed Forces at Sea (Geneva Convention No. II), Aug. 12, 1949, 75 U.N.T.S. 85; Geneva Convention Relative to the Treatment of Prisoners of War (Geneva Convention No. III), Aug. 12, 1949, 75 U.N.T.S. 135; Convention Relative to the Protection of Civilian Persons in Time of War (Geneva Convention No. IV), Aug. 12, 1949, 75 U.N.T.S. 287 [hereinafter Geneva Conventions].

305 Namely, the prohibition deriving from s 71 in ch III of the Constitution, which provides that "[t]he judicial power of the Commonwealth shall be vested in ... the High Court of Australia, and in such other federal courts as the Parliament creates, such other courts as it invests with federal jurisdiction." The latter courts are identified in s. 77(ii) as "the courts of the States."

306 War Crimes Act Case, 172 CLR at 501 (Austl.).

307 Id. at 530.

308 Id. 
principle or standard formulated in advance of the events to which it is sought to be applied." ${ }^{309} \mathrm{He}$ then discussed the issue under United States jurisprudence:

Article 1, s. 9, cl. 3 and Art. 1, s. 10, cl. 1 of the United States Constitution prohibit any State as well as Congress from passing a bill of attainder or an ex post facto law. A bill of attainder is a legislative enactment which inflicts punishment without a judicial trial; initially a bill of attainder provided for punishment by death but in the context of the constitutional prohibition such a bill is now regarded as including what was formerly a bill of pains and penalties: Cummings v. Missouri. ${ }^{310}$ An ex post facto law, of which a bill of attainder was, or might be, an instance, is a retrospective law which makes past conduct a criminal offence. ${ }^{311}$

In distinguishing the 1945 Act, Chief Justice Mason points out that: "The constitutional prohibition against bills of attainder and ex post facto laws was not an expression of the antecedent common law of England." ${ }^{312}$ He then discussed a number of United States cases which suggest that the prohibition on bills of attainder was part of the doctrine of separation of powers, ${ }^{313}$ concluding that "a statute which contains no declaration of guilt and does not impose punishment for guilt is not a usurpation of judicial power."314

Justice Deane found the Act to be valid under the external affairs power, given precedents in support of the proposition that "law with respect to matters or things which are territorially outside Australia is a law with respect to 'External affairs' for the purposes of s. 51(xxix)." 315

As to the Chapter III invalidity argument, Justice Deane dissented from the majority. While he stated that the Act will not contravene the doctrine of separation of powers merely because it operates retrospectively, ${ }^{316}$ he then cited Phillips $v$. Eyre, ${ }^{317}$ where the Court of Exchequer Chamber identified: "the central vice of a Bill of Attainder not as lying in its specific naming of an individual but as lying in its ex post facto operation as a legislative decree that an act which was not criminal when done was 'voided and punished' as a crime." 318 Then Justice Deane referred to the United States doctrine of separation of power, noting "that the United States Constitution contains express prohibitions of any 'Bill of Attainder or ex post facto Law' (Art. I, §9, cI. 3 (Federal) and Art. I, §10, d. 1 (State): 'the Bill of Attainder Clause') which does not appear in [the Australian] Constitution.." ${ }^{119}$ He goes on to explain that: "a prohibition of ex post facto criminal laws was implicit in the doctrine of separation of judicial power which those United States provisions

\footnotetext{
Id. at 533 .

Cummings v. Missouri, 71 U.S. 277 (1866).

1 War Crimes Act Case, 172 CLR at 535 (Austl.).

312 Id. (citing Calder v. Bull, 3 U.S. 386, 389 (1798)).

313 Id. at 536-37.

$314 \quad I d$. at 537.

$315 \quad I d$. at 599.

316 Id. at 608. Cf., e.g., R v Kirby; Ex parte Boilermakers' Soc'y of Austl ("Boilermakers Case") (1956) 94 CLR 258, 281 (Austl.).

317 Phillips v. Eyre [1870] LR 6 QB 1 (Eng.).

318 War Crimes Act Case, 172 CLR at 611 (Austl.).

319 Id. at 616.
} 
embodied supports the conclusion that Ch. III precludes the enactment of such a law." 320

As to Justice Dawson, he believed that based on recent Australian authority that the reach of the external affairs power extends to "all places, persons, matters or things geographically external to Australia." ${ }^{21}$ As to the Chapter III argument, he also found for the proposition that the Commonwealth Parliament may in the exercise of its legislative powers create retrospective laws, "including criminal laws with an ex post facto operation", 322 and that the Australian Constitution contains no provision which corresponds to the bill of attainder clause in the United States Constitution, adopts in its entirety the United States theory of the separation of powers. ${ }^{323}$ He then stated that: "The fact that the Act lays down rules of conduct in relation to events which occurred before it came into effect does not invest it with the attributes of a bill of attainder, however widely such an instrument is defined." 324

Justice Toohey agreed on the validity of the Act, although his reasoning was that the Act "was a law with respect to matter external to Australia which touched and concerned the national interest of Australia", and because the Act "was an exercise of the universal jurisdiction to prosecute war crimes and crimes against humanity as formulated in international law at the relevant time." 325 His honor adopted the reasons given by Justice Brennan (see below) for the proposition that the 1945 Act is not supported by the defense power (section 51(vi)). In relation to the third argument, relating to Chapter III of the Australian Constitution, he stated that only a law that purports to require a court to act contrary to "accepted notions of judicial power" would contravene Chapter III. ${ }^{326}$ However, a law that is operates retrospectively does not necessarily offend Chapter III, ${ }^{327}$ which is the case applicable to the impugned 1945 Act. ${ }^{328}$

Justice Gaudron found that 1945 Act valid under the external affairs power (section 51(xxix)) by reason that "it operates upon acts, matters or things outside Australia", 329 while finding no basis on which the Act can be said "to be in the slightest degree relevant to defense." ${ }^{\text {330 }}$ As to violating Chapter III, her honor stated that the Act would be invalid under this ground, only where such intention is revealed "revealed by unmistakable language." 331

Justice McHugh also adopted a wider interpretation of the external affairs power (section 51(xxix)), finding the Act valid under the power by reason that "the Act penalizes conduct constituting a war crime which occurred outside Australia." ${ }^{\prime 32}$ Finding so, he did not entertain validity under section 51(vi).

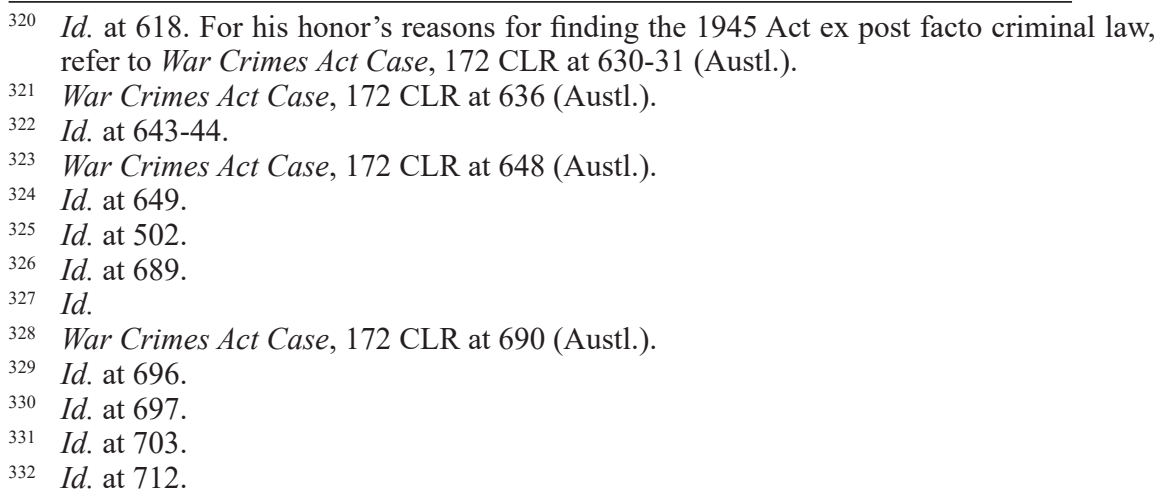


As to the retrospective operation of the Act and its validity under Chapter III, Justice McHugh stated the following:

In my opinion, the enactment of laws having a retrospective operation does not infringe the constitutional guarantee that the judicial power of the Commonwealth can be exercised only by courts established and judges appointed in accordance with Ch. III of the Constitution, and by such other courts as are invested with federal jurisdiction. ${ }^{333}$

His honor then compares the express prohibition on bills of attainder and ex post facto laws in the United States Constitution with the Chapters I to III of the Australian Constitution. ${ }^{334} \mathrm{He}$ comes to the conclusion that "although Chs I, II and III reflect Arts I, II and III of the United States model, our Constitution does not prohibit Bills of Attainder or ex post facto laws. The omission must have been deliberate", ${ }^{335}$ finding that "Retrospectivity is not itself sufficient to offend Ch. III of the Constitution." 336

In his dissent, Justice Brennan was however of the view that the external power required a connection with Australia and the subject matter of the 1945 Act, which in his view in this case did not exist: "the mere acquisition of Australian citizenship or residence in Australia does not transform earlier extraterritorial conduct that was not a matter of Australia's external affairs when it was engaged in into a matter of Australia's external affairs." ${ }^{337}$ As to the argument that the external affairs power is engaged given that the 1945 Act discharges Australia's international obligations, his honor canvased relevant United Nations Resolutions, ${ }^{338}$ and referred to a 1965 resolution $^{339}$ that states these obligations as follows: "in accordance with international law and national laws, the criminals responsible for war crimes and crimes against humanity are traced, apprehended and equitably punished by the competent courts", ${ }^{340}$ and to the Geneva Conventions of $1949 .{ }^{341}$ However, he then stated the following:

Although the material demonstrates that there was a widespread aspiration that the war criminals of the Axis powers should be brought to justice after the Second World War and although that aspiration was repeated in a series of resolutions in the UNGA and in the Economic and Social

333 War Crimes Act Case, 172 CLR at 719 (Austl.).

334 Id. at $719-20$.

335 Id. at 720.

336 Id. at 721 .

337 Id. at 555.

338 Especially, United Nations General Assembly resolution on the Extradition and Punishment of War Criminals, G.A. Res. 3 (I) (Feb. 13, 1946), which was reaffirmed by the resolution on the Surrender of War Criminals and Traitors, G.A. Res. 170 (II) (Oct. 31, 1947), and the General Assembly Declaration on the Principles of International Cooperation in the Detection, Arrest, Extradition and Punishment of Persons Guilty of War Crimes and Crimes Against Humanity, G.A. Res. 3074 (XXVIII) (Dec. 3, 1973).

339 Economic and Social Council Res. 1965/39 (July 28, 1965).

340 War Crimes Act Case, 172 CLR at 558 (Austl.).

${ }^{341}$ Id. 
Council, the practice of States in the community of nations does not reveal a widespread exercise of jurisdiction to try alleged war criminals for extraterritorial war crimes. European States have exercised jurisdiction in respect of war crimes committed in their respective territories, but Israel and Canada are the only States which have asserted jurisdiction to try alleged war criminals in respect of extraterritorial war crimes. ${ }^{342}$

Justice Brennan then looked at the sources of international law and found no customary law obligation to try alleged war criminals in respect of extraterritorial war crimes, ${ }^{343}$ because there was "no evidence of widespread State practice which suggests that States are under a legal obligation to seek out Axis war criminals and to bring them to trial. There is no opinio juris supportive of such a rule. ${ }^{" 344}$ However, of particular interest is his honor's distinguishing of American cases where he stated that: "The jurisdiction of the courts of the United States to try cases of international crime was founded on the application by municipal courts of international law", ${ }^{345}$ and that "the Court spoke in terms which suggested that the courts of the United States applied international law directly as part of the municipal law of the United States." 346

Justice Brennan also accepted the second and third grounds for invalidity. In relation to the defense power (section 51(vi)), Justice Brennan found the 1945 Act to be invalid given that the application of the defense power would not be reasonably proportional in a time of peace. ${ }^{347}$ As to the retrospectivity argument, Brennan $J$ accepted that international law does not create an international crime retrospectively, ${ }^{348}$ and condemns retrospective municipal criminal law as offensive to human rights. ${ }^{349}$

In summary, the War Crimes Act Case reflects a complexity sourced in comparative analysis between international human rights law, the United States Constitution, and the Australian Constitution under two legislative powers, namely the external affairs and defense powers, and under the doctrine of separation of powers, as reflected in Chapter III judicial independence in the Australian Constitution.

\footnotetext{
Id. at 559 .

Id.

${ }^{344} I d$. at 560 .

${ }^{345} I d$. at 566-67 (citing United States v. Smith, 18 U.S. 153, 161 (1820), where the Supreme Court of the United States held that American common law "recognizes and punishes piracy as an offence, not against its own municipal code, but as an offence against the Law of Nations (which is part of the Common Law), as an offence against the universal law of society; a pirate being deemed an enemy of the human race").

346 War Crimes Act Case, 172 CLR at 567 (Austl.). See Ex parte Quirin, 317 U.S. 1, 27-28 (1942) (also cited by Justice Brennan in War Crimes Act Case, 172 CLR 501 (Austl.)). Cf. Application of Yamashita, 327 U.S. 1, 16 (1946), where the Court spoke in more guarded language, observed that "We do not make the laws of war but we respect them so far as they do not conflict with the commands of Congress or the Constitution." ( $C f$. U.S. CONST. art. I, $\S 8$, cl. 10 which confers on the Congress power "To define and punish Piracies and Felonies committed on the high Seas, and Offences against the Law of Nations.")

347 War Crimes Act Case, 172 CLR at 592 (Austl.).

$348 \quad I d$. at 572.

349 Id. at 575.
} 


\section{SCHOOL Chaplains CASE}

While this case $\mathrm{e}^{350}$ does not delve into the tension between international and domestic law under the dualist approach, it deals with comparative analysis between the United States, the Canadian, and Australian Constitutions. For example, Chief Justice French looked at the 1891 draft of the Australian Constitution and how it was "based upon the Constitution of the United States in so far as it assigned enumerated legislative powers to the Federal Parliament", and how the executive power "followed the Constitution of Canada embodied in the British North America Act 1867 (Imp)." ${ }^{351}$ He points out to the hybrid nature of the Australian Constitution, being based on British, United States, and Canadian constitutional designs, ${ }^{352}$ and explains the incompatibility between a British-style cabinet system of executive government, and a true federation. ${ }^{353}$

In the School Chaplains Case, Ronald Williams challenged an agreement between the Commonwealth and the Scripture Union of Queensland (SUQ) for the provision of chaplaincy services at schools in Queensland, one which attended by Williams children. Williams argued that given that the agreement was not entered into pursuant to any legislation, the executive has no power to fund the provision of such services.

A six-to-one majority (Justice Heydon dissenting) found the agreement invalid as the Commonwealth had no constitutional or legislative power to enter into the agreement. In particular, section 61 executive power in the Australian Constitution did not authorize making payments to the SUQ. ${ }^{354}$

The source of complexity in this case comes from an inherent contradiction in the design of the Australian Constitution, namely the tension between the doctrine of responsible government, a British concept, and the federal compact, and American concept. The contradiction is explained by Quick and Garran in the following terms:

[I]n a Federation, it is a fundamental rule that no new law shall be passed and no old law shall be altered without the consent of (1) a majority of the people speaking by their representatives in one House, and (2) a majority of the States speaking by their representatives in the other house; that the same principle of State approval as well as popular approval should apply to Executive action, as well as to legislative action; that the State should not be forced to support Executive policy and Executive acts merely because ministers enjoyed the confidence of the popular Chamber. ${ }^{355}$

350 Williams v Commonwealth [No1] ("School Chaplains Case") (2012) 248 CLR 156.

351 Id. at 195.

352 School Chaplains Case, 248 CLR at 202-03 (Austl.).

353 Id. (citing John Quick \& Robert Randolph Garran, The ANNOtated Constitution of the Australian Commonwealth 706 (1901)).

354 Section 61 reads as follows:

Executive power:

The executive power of the Commonwealth is vested in the Queen and is exercisable by the Governor-General as the Queen's representative, and extends to the execution and maintenance of this Constitution, and of the laws of the Commonwealth.

355 John Quick \& Robert Randolph Garran, The Annotated Constitution of the 
The invalidity of the agreement with the SUQ led the Commonwealth to enact remedial legislation. ${ }^{356}$ This time, Williams again successfully challenged the validity of the Act, as not supported by any constitutional powers, in particular, the corporations power section 51(xx) (given that the SUQ was a corporation) and the power to provide benefits to students (section 51(xxiiiA)). ${ }^{357}$ Unanimously, the HCA found the Act extended beyond the corporations and student benefits powers. ${ }^{358}$

In summary, unlike the other outliers, the complexity arising in School Chaplains Case is found in the hybrid design of the Australian Constitution rather than in tension between competing rights or between international and domestic rules. Notwithstanding, the complexity reflects a tension that we have seen previously, namely that between vertical levels of government.

\section{A COMmon Denominator?}

Beyond the observation that nine outliers have common constitutional law issues, can we formulate a more nuanced proposition as to the source of the complexity inherent in the 12 outliers discussed above? The answer is "yes." The analysis in the previous section provides three possible common denominators for the complexity identified in the twelve outliers. These are listed in Table 2 below.

Table 2: Main sources of outlier complexity.

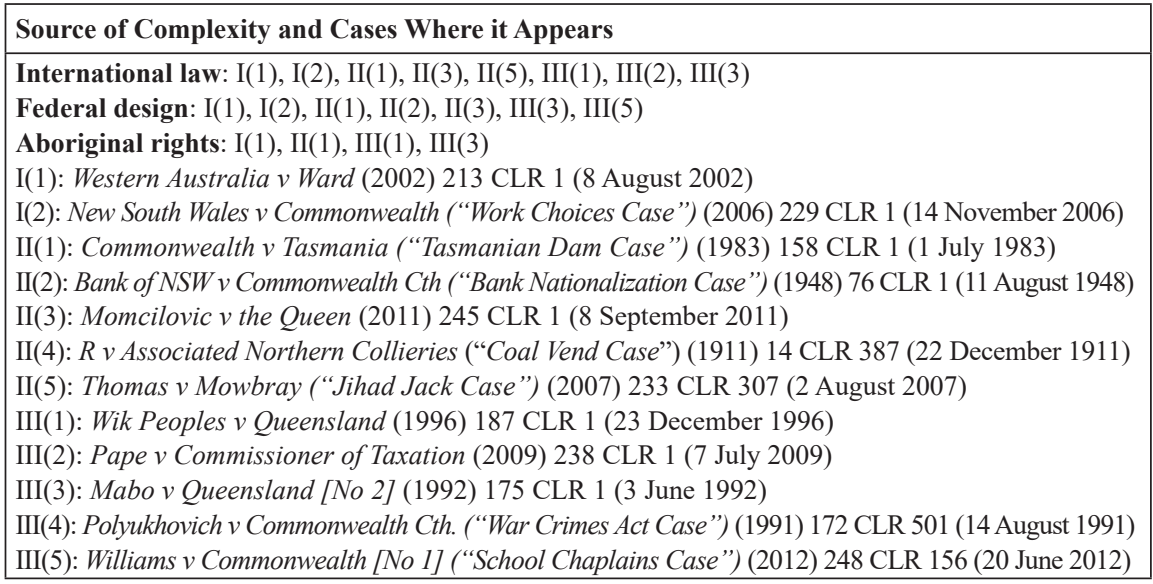

As can be seen in Table 2, there are three common denominators: international law, federal design, and Aboriginal rights. While first-tier cases are concerned with section 109 inconsistency issues between State and Commonwealth legislation, at a deeper

Australian Commonwealth 706 (1901).

356 Financial Framework Legislation Amendments Act (No 3) 2012 (Cth) (Austl.).

357 Williams v Commonwealth [No 2] (2014) 252 CLR 416 (Austl.).

$358 \quad I d$. at 417. 
level, the inconsistencies arise from deficiencies in the protection of rights. For example, in Ward, there is competition between native title rights and pastoral leases, including the right of Aboriginal Australians not to be discriminated against. Another issue that arises in first-tier of cases is the validity of Commonwealth legislation, the analysis of powers in the Australian Constitution relied on by the Commonwealth to pass legislation. A deeper analysis shows that the underlying issues are related to the protection of rights, especially, under international conventions. In second-tier cases we find validity analysis under Chapter III of the Australian Constitution. But even here the underlying analysis is largely governed by the protection of human rights. In Momcilovic, the tension discussed in terms of one of the few human rights Acts in Australia, ${ }^{359}$ and the tension between the protection of rights and state legislation. Third-tier cases also reflect complexity arising from Aboriginal rights, international law, and the federal compact. In addition to analysis of the doctrine of separation of powers under Chapter III, and analysis of powers under the Australian Constitution, these cases look at the validity of state legislation under section 92 and in relation to extra-territorial operation. There is a connection with the protection of human rights, such as in School Chaplains Case, but on the actual analysis by the High Court, the connection to rights is relatively tenuous.

Most of the outliers analyze the tension between the Australian Constitution and different types of rights (e.g., Aboriginal rights, workers' rights, fundamental human rights and environmental rights). More specifically, eight of the outliers (I(1), II(1, 2, 3, and 5), III(1, 3, and 4)) illustrate the difficulty of protecting different types of rights, and High Court reluctance to be informed by relevant international law and United States jurisprudence. The high complexity observed in these outliers is a signifier of a deeper, structural issue with rights in Australian constitutional law. This observation could be summarized as relating to the lack of an Australian Bill of Rights, and whether that might be what is underlying the registered complexity in the outliers discussed above.

However, all three common denominators in Table 2 result from comparative analysis with United States jurisprudence, featuring in all 12 outliers. United States jurisprudence overlaps with these other sources, especially federal design and Aboriginal rights. The HCA analysis of United States jurisprudence informs the vertical balance of powers between the States and the Commonwealth, and informs the relationship between Australian Aboriginals and the Crown. The cases also show reliance by litigants on United States jurisprudence in interpreting international conventions, as discussed below.

In Ward, the above sources of complexity can be understood in terms of the comparative analysis, initiated by the litigants, and delineated by members of the High Court, with the United States. ${ }^{360}$ For example, in his dissenting judgment, Justice Callinan looked at interpreting the International Convention on the Elimination of all Forms of Racial Discrimination using US jurisprudence, arguing the possibility of pursing the Convention using limited means. ${ }^{361}$ He makes specific

\footnotetext{
359 At the state level, we find three human rights Acts in ACT, Victoria, and Queensland. The Human Rights Act 2004 (ACT) (Austl.), the Charter of Human Rights and Responsibilities Act 2006 (Vic) (Austl.), and the Human Rights Bill 2018 (Q1d) (Austl.).

360 Ward, 213 CLR at 16 (Austl.).

361 Id. at 283 n. 833 .
} 
reference to Rodriguez v. United States, ${ }^{362}$ in support of this interpretation. He also refers to Washington v. Davis, ${ }^{363}$ in holding that "mere discriminatory effect [under the Convention] without discriminatory purpose is not sufficient to found a violation of the equal protection clause of the Fourteenth Amendment of the United States Constitution." 364

In the Work Choices Case, similar to Ward, the majority referred extensively to United States jurisprudence, ${ }^{365}$ especially the Interstate Commerce Act 1887 (US), ${ }^{366}$ and the Sherman Act 1890 (US), ${ }^{367}$ which were supported by the Commerce Clause, ${ }^{368}$ for the proposition that United States federal courts have the power to intervene by injunction in labour disputes. ${ }^{369}$

Chief Justice Gleeson and Justices Gummow, Hayne, Heydon and Crennan make specific reference to In re Debs, ${ }^{370}$ which "supported the intervention of the federal government in the Pullman Strike to break the strike by force." Their honors also cite McCulloch v. Maryland, ${ }^{372}$ to make analogies with the Commonwealth power to creating the Commonwealth Bank, and that of Congress in creating the Bank of the United States. ${ }^{373}$

United States jurisprudence is again prominent in the High Court reasoning in the Tasmanian Dam Case. The case illustrates an extensive comparative analysis, especially with the Fifth Amendment of the United States Constitution. ${ }^{374}$ Justice Mason, for example, looks at Justice Stephen's distinction between "taking" property and "regulation" of property in Tooth, ${ }^{375}$ but comes to the conclusion that

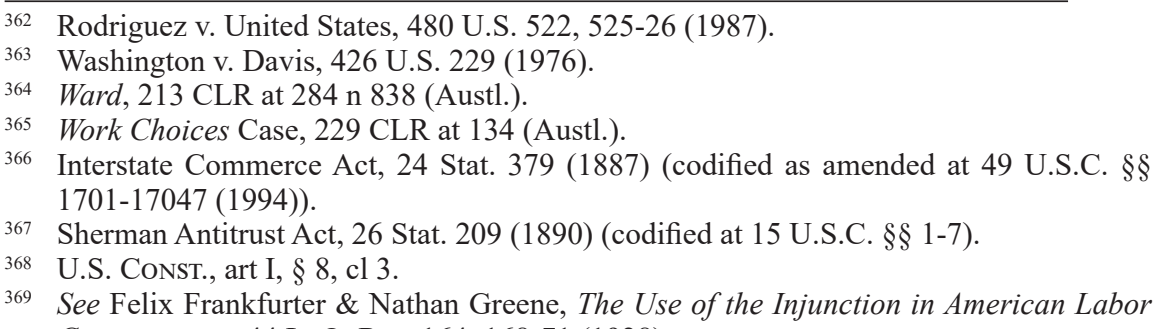
Controversies, 44 L. Q. Rev. 164, 168-71 (1928).

370 In re Debs, 158 U.S. 564, 582 (1895).

371 Work Choices Case, 229 CLR at 126 (Austl.). See also their general statement that "the United States federal courts had intervened by injunction in labour disputes" (Work Choices Case, 229 CLR at 134 (citing Felix Frankfurter \& Nathan Greene, The Use of the Injunction in American Labor Controversies, 44 L. Q. REv. 164, 168-71 (1928))).

372 McCulloch v. Maryland, 17 U.S. 316 (1819). In this case, the Supreme Court upheld the incorporation in 1816 by the Congress of the Bank of the United States. As stated in Work Choices Case, 229 CLR at 126 n 355, "[...]By the time of the adoption of the Australian Constitution, the Supreme Court had upheld laws for the creation of corporations to construct railroads and bridges for the purpose of promoting interstate commerce: Luxton v North River Bridge Co (1894) 153 U.S. 525 at 529-530”.

373 Work Choices Case, 229 CLR at 124 (Austl.). See also their quote from Joseph Story at Work Choices Case, 229 CLR at 126 (Austl.), confirming that the power to erect corporations may also be implied. The test being "whether it be such an instrument or means, and have a natural relation to any of the acknowledged objects of government." Joseph Story, Commentaries on the Constitution of the United States $447 \S 622$ (1833).

374 Tasmanian Dam Case, 158 CLR at 5, 247, 284 (Austl.).

375 Trade Practices Commission v Tooth \& Co Ltd (1979) 142 CLR 397, 413-15 (Austl.). See Tasmanian Dam Case, 158 CLR at 144. 
"[t]he decisions of the United States Supreme Court have no direct relevance to s. 51 (xxxi) of the Constitution." 376 This is so given that:

Many of [the decisions] turn on the Fifth Amendment which is made applicable to the states by the Fourteenth Amendment: see, e.g., Penn Central Transportation Co. v. New York City, ${ }^{377}$ in which Pennsylvania Coal was explained on the footing that a State statute that substantially furthers important public policies may so frustrate distinct investment backed expectations as to amount to a "taking." The relevant provision in the Fifth Amendment is “... nor shall private property be taken for public use, without just compensation." It seems that the Supreme Court has proceeded according to the view that the object of the clause is to prevent government from forcing some people alone to bear public burdens which should be undertaken by the entire public: Armstrong v. United States (24); National Board of Young Mens Christian Assns. v. United States (25); Penn Central.

The emphasis in $\mathrm{s} .51$ (xxxi) is not on a "taking" of private property but on the acquisition of property for purposes of the Commonwealth. To bring the constitutional provision into play it is not enough that legislation adversely affects or terminates a preexisting right that an owner enjoys in relation to his property; there must be an acquisition whereby the Commonwealth or another acquires an interest in property, however slight or insubstantial it may be..$^{378}$

Justice Murphy finds support for the presumption in favor of the validity of a legislative Act in United States jurisprudence, indicating that the presumption "was 'thoroughly established' by 1811",379 and that United States Supreme Court referred to "the rule that every reasonable intendment must be indulged in favor of the constitutionality of a legislative power exercised." ${ }^{380}$ As a corollary, of the presumption of validity, must also be presumed "all the facts and circumstances essential to the validity [of the Act]. ${ }^{\prime 381}$ He then cited the United States Supreme Court "[i]f no state of circumstances could exist to justify such a statute, then we may declare this one void, because in excess of the legislative power of the State.

376 Tasmanian Dam Case, 158 CLR at 144 (Austl.).

377 Penn Cent. Transp. Co. v. City of New York, 438 U.S. 104 (1978).

378 Tasmanian Dam Case, 158 CLR at 144-45 (Austl.).

379 Id. at 163 (citing James B. Thayer, The Origin and Scope of the American Doctrine of Constitutional Law, 7 Harv. L. Rev. 129, 150 (1893); the classic statement of the doctrine of "reasonable doubt" by Justice Washington in Ogden v. Saunders, 25 U.S. 213, 270 (1827); Fletcher v. Peck, 10 U.S. 87, 128 (1810) (Marshall, C.J.); Pure Oil Co. v. Minnesota, 248 U.S. 158, 162-63 (1918); Bd. of Trade of City of Chicago v. Olsen, 262 U.S. 1, 37-38 (1923); Gitlow v. New York, 268 U.S. 652, 668 (1925).; Davies Warehouse Co. v. Bowles, 321 U.S. 144, 153 (1944); United States v. Five Gambling Devices, 346 U.S. 441, 449 (1953); Hodel v. Virginia Surface Mining and Reclamation Ass'n, Inc., 452 U.S. 264, 276 (1981).

380 First Nat'l Bank of Bay City v. Fellows ex rel. Union Tr. Co., 244 U.S. 416, 422 (1917). See Tasmanian Dam Case, 158 CLR at 164.

381 Tasmanian Dam Case, 158 CLR at 167 (Austl.). 
But if it could, we must presume it did", ${ }^{382}$ and "when the classification made by the legislature is called in question, if any state of facts reasonably can be conceived that would sustain it, there is a presumption of the existence of that state of facts." 383 And that those challenging the legislative judgment "must convince the court that the legislative facts on which the classification is apparently based could not reasonably be conceived to be true by the governmental decisionmaker." ${ }^{8} 84$

Justice Brennan also looks at the Fifth Amendment, arguing that private property should not be "taken" without just compensation. He cites the Supreme Court as construing the provision as one "designed to bar Government from forcing some people alone to bear public burdens which, in all fairness and justice, should be borne by the public as a whole." " 385 However, he also cites the difficulty identified by the Supreme Court in finding "a touchstone for applying the limitation to some regulatory laws and not to others." 386

Justice Deane also looks at United States jurisprudence in considering the scope of the external affairs power, in particular, his honor refers to the Burgess' Case, and the test in relation to the United States treaty-making power, that there has to be "sufficient international significance to make it a legitimate subject for international cooperation and agreement." 387 His honor also refers to Tooth. ${ }^{388}$ Justice Stephen referred to the distinction which has been recognized in the United States between the regulation of proprietary rights and the taking of property, for example, in Penn Central Transportation Co. v. New York City. ${ }^{389}$

Similar to the other outliers, also both plaintiffs and defendants in the Bank Nationalization Case referred to United States jurisprudence, this time on the definition of banking. ${ }^{390}$ Chief Justice Latham refers to cases from the United States on the precise definition of banking, finding that "in none of these cases was it necessary to formulated a precise definition of banking in order to apply any constitutional provisions upon the subject." ${ }^{391}$ Citing McCulloch v. Maryland, ${ }^{392}$ his honor points out that "there is no constitutional provision dealing with the subject of banking and

382 Munn v. Illinois, 94 U.S. 113, 132 (1876).

383 Borden's Farm Prod. Co. v. Baldwin, 293 U.S. 194, 209 (1934).

384 Vance v. Bradley, 440 U.S. 93, 111 (1979) (citing Lindsley v. Natural Carbonic Gas Co., 220 U.S. 61, 78-79 (1911); Schilb v. Kuebel, 404 U.S. 357, 364 (1871); United States v. Maryland Savings-Share Ins. Corp., 400 U.S. 4, 6 (1970); McGinnis v. Royster, 410 U.S. 263, 274 (1973); Williamson v. Lee Optical Co., 348 U.S. 483, 487 (1955)). See also Lindsley v. Natural Carbonic Gas Co., 220 U.S. 61, 78 (1911); Ohio, ex rel. v. Deckebach, 274 U.S. 392, 397 (1927); Lawrence v. State Tax Comm'n of Mississippi, 286 U.S. 276, 283 (1932); United States v. Carolene Products Co., 304 U.S. 144, 152 (1938); McGowan v. Maryland, 366 U.S. 420, 426 (1961); United States v. Maryland Savings-Share Ins. Corp., 400 U.S. 4, 6 (1970); Schilb v. Kuebel, 404 U.S. 357, 364 (1971); McGinnis v. Royster, 410 U.S. 263, 274 (1973); U.S. R.R. Ret. Bd. v. Fritz, 449 U.S. 166, 175 (1980).

385 Tasmanian Dam Case, 158 CLR at 247 (Austl.) (citing Armstrong v. United States, 364 U.S. 40, 49 (1960)).

386 Tasmanian Dam Case, 158 CLR at 248 (Austl.) (citing Penn Central Transportation Co. v. City of New York City, 438 U.S. 104, 124 (1978)).

387 Tasmanian Dam Case, 158 CLR at 257 (Austl.). See Westel Woodbury Willoughby, Constitutional LaW of the United States 519 (2nd ed., 1929).

388 Trade Practices Commission v Tooth \& Co (1979) 142 CLR 397, 414-15 (Austl.).

389 Penn Central Transp. Co. v. City of New York City, 438 U.S. 104, 123-28,139-46 (1978).

390 See, e.g., The Bank Nationalization Case, 76 CLR at 192, 278 (Austl.).

391 Id. at 192.

392 McCulloch v. Maryland, 17 U.S. 316 (1819). 
the American authorities cited are of little assistance", ${ }^{393}$ and that the incidental power is the source of the power of the Congress "to make laws with respect to banking." 394 His honor also referred to United States jurisprudence to find that "The cases in the United States in which reference is made to banking do not include any considered decision of the question whether banking is trade or commerce." ${ }^{395}$

Chief Justice Latham also makes reference to United States v. Darby, ${ }^{396}$ and the proposition that in the United States "the power of Congress to "regulate commerce with foreign nations and among the several States' has on very many occasions been held to extend "not only to those regulations which aid, foster and protect the commerce, but [it] embraces those which prohibit it." ${ }^{397} \mathrm{He}$ also explains that "in the United States of America the Supreme Court has jurisdiction in all 'controversies to which the United States shall be a party' - Constitution of the United States, Art. Ill., s. 2. But this jurisdiction can be exercised only if the United States consents." ${ }^{\prime 398}$ Then his honor distinguishes section 75(iii) of the Australian Constitution ("In all matters in which the Commonwealth, or a person suing or being sued on behalf of the Commonwealth, is party, the High Court shall have original jurisdiction") in the following terms:

In the Commonwealth Constitution the words used are not "a party to a controversy," but "being sued on behalf of the Commonwealth." In the case of the United States Constitution there is much to be said for the proposition that the court should look at the controversy, whatever it may be, and ascertain who are the real parties to it, whoever or whatever may be the agents through whom they act. But in the case of the Commonwealth Constitution the reference to the record is much more direct. It is necessary only to find out who is actually being sued and then to ask whether that person is being sued on behalf of the Commonwealth. ${ }^{399}$

In their joint opinion, Justices Rich and Williams also look at United States v. Thayer-West Point Hotel Co.,${ }^{400}$ for the proposition that

[F]or the acquisition of income-producing property must, in order to provide just terms, empower the tribunal which is to assess the compensation to award interest from the date the acquirer enters into possession, so that, if the law provides for the assessment of "compensation," this word, read in the light of constitutional requirement, should be construed as including such a power in its content. ${ }^{401}$

\footnotetext{
Bank Nationalization Case, 76 CLR at 192 (Aust.).

Id.

395 Id. at 233.

396 United States v. Darby, 312 U.S. 100 (1941).

397 Bank Nationalization Case, 76 CLR at 197-98 (Austl.) (citing United State v. Darby, 312 U.S. 100, 113 (1941)).

398 Id. at 225 (citing Westel W. Willoughby, Constitutional Law of the United States 1381, 1422 (2nd ed., 1929)).

399 Id. at $225-26$.

400 United States v. Thayer-West Point Hotel Co., 329 U.S. 585 (1947).

401 Bank Nationalization Case, 76 CLR at 277 (Austl.).
} 
They also refer to Freeman v. Hewitt, ${ }^{402}$ to support the view that banking was part of commerce, and refer to Atlantic Cleaners \& Dyers Inc. v. United States, ${ }^{403}$ to ascertain the meaning of trade. ${ }^{404}$

Justice Starke refers to McCulloch v. Maryland, ${ }^{405}$ making the same point made by Chief Justice Latham on the power of Congress to incorporate banks, stating that the power was "deduced by inference or implication from the Constitution." 406 His honor also looks at section 92 of the Australian Constitution (stipulating for trade within the Commonwealth to be free) and compares it to "the power in the American Constitution to regulate commerce with foreign nations and among the several States and with the Indian tribes." 407 Justice Starke then cites with approval Chief Justice Marshall in Gibbons v. Ogden, ${ }^{408}$ on the "intercourse" description of commerce. ${ }^{409}$ However, on a contextual analysis of the Australian Constitution, he nevertheless distinguishes the United States doctrine giving Congress the exclusive power regulate commerce, where there is a requirement of uniformity of regulations, while allowing the States jurisdiction over matters admitting diversity of treatment, until Congress decides otherwise. ${ }^{410}$ Justice Starke also follows Chief Justice Latham's approach on distinguishing the interpretation of section 75(iii) of the Australian Constitution from the Supreme Court interpretation of the Case or Controversy Clause. ${ }^{411}$

Similarly, Justice Dixon looked at New York v. United States, ${ }^{412}$ in rejecting the point in relation to discriminating against the states in curtailing their freedom in using the general banking system. ${ }^{413} \mathrm{He}$ then goes to distinguish the "just compensation" requirement under the Fifth Amendment of the United States Constitution form that under section 51(xxxi) of the Australian Constitution, ${ }^{414}$ citing the statement form Thayer-West Point Hotel Co., ${ }^{415}$

The fact that 'just compensation' includes interest in the eminent domain setting does not necessarily mean that the term must be given the same scope in other situations ... in the absence of constitutional connotations, 'just compensation' is not a term of art so far as interest is concerned. ${ }^{416}$

Justice Dixon goes on and provides a comparative analysis with the United States Constitution on interpreting section 92 "trade and commerce", similar to that given




by the other members of the bench. ${ }^{417}$

Similarly, in Momcilovic, as to its comparative analysis with the United States Constitution, Chief Justice French looks at the $19^{\text {th }}$ century Supreme Court proposition that the presumption of innocence and the prosecutor's burden of proof are "logically separate and distinct", and how "sharp scholarly criticism" resulted in discarding the distinction. ${ }^{418}$

Justice Gummow looks at decisions of the Supreme Court of the United States, ${ }^{419}$ for the proposition that "the diversity jurisdiction established by Art III $\S 2$ of the United States Constitution did not extend to criminal proceedings", ${ }^{420}$ and for comparing covering cl 5 of the Australian Constitution with the Supremacy Clause of the United States Constitution, ${ }^{421}$ only to emphasize that "the position of the States in the Australian federal structure does not correspond to that of the States in the American federal structure." ${ }^{222}$ Justice Hayne also makes reference to Joseph Story in his commentary on the United States Constitution, ${ }^{423}$ in comparing Article VI of the United States Constitution, and section 109 of the Australian Constitution, and in support of the proposition that "despite the differences between the two systems, these particular observations apply with equal force to the Commonwealth Constitution and serve to explain why laws of the Commonwealth, validly made, are and must be paramount." 424

Justices Crennan and Kiefel also make use of United States cases, citing Mistretta v. United States, for the proposition that "the reputation of the judicial branch may not be borrowed by the legislative and executive branches 'to cloak their work in the neutral colors of judicial action." "425

In the Coal Vend Case, in discussing the validity of the 1906 Act, Justice Isaacs refers to similar enactments in the United State, ${ }^{426}$ and uses United States v. American Tobacco Co. ${ }^{427}$ to ascertain the meaning of "restraint of trade." ${ }^{28} \mathrm{He}$ also refers to Justice Holmes in Swift v. United States, ${ }^{429}$ to discuss the validity of the agreement in the Coal Vend Case. ${ }^{430}$ The case shares an extensive comparative

417 Bank Nationalization Case, 76 CLR at 366-82 (Austl.)

418 Momcilovic v The Queen (2011) 245 CLR 1, 51-52 n 255 (Austl.) (citing Coffin v. United States 156 U.S. 432 (1985); Taylor v. Kentucky, 436 U.S. 478, 483 (1978)). See also John William Strong et al., McCormick ON Evidence, 519-20 (5th ed., 1999); William S. Laufer, The Rhetoric of Innocence, 70 WASH. L. Rev. 329 (2005); Larry Laudan, The Presumption of Innocence: Material or Probatory?, 11 Legal Theory 333 (2005); David Hamer, A Dynamic Reconstruction of the Presumption of Innocence, 31 OxFORD J. Legal Stud. 417 (2011).

419 Chisholm v. Georgia, 2 U.S. 419, 431-32 (1793); Wisconsin v. Pelican Ins. Co., 127 U.S. 265, 289-90, 298 (1888).

420 Momcilovic, 245 CLR at 81 (Austl.).

${ }^{421}$ Id. at 101-03 (U.S. Const. art. VI, cl. 2).

422 Id. at 81 n.376 (citing John Pfeiffer Pty Ltd v Rogerson (2000) 203 CLR 503 (Austl.)).

423 Momcilovic, 245 CLR at 131 (Austl.) (citing Joseph Story, Commentaries ON THE Constitution of the United States 693 § 1831 (1833).

${ }^{424}$ Id. at 132.

$425 I d$. at 228 (citing Mistretta v. United States, 488 U.S. 361, 407 (1989)).

426 Coal Vend Case, 14 CLR at 404 (Austl.).

427 United States v. American Tobacco Co., 221 U.S. 106, 178; (1911).

428 Coal Vend Case, 14 CLR at 457 (Austl.).

429 Swift \& Co. v. United States, 196 U.S. 375, 396 (1905).

430 Coal Vend Case, 14 CLR at 476 (Austl.). 
analysis with United States jurisprudence, especially in relation to anti-trust laws. ${ }^{431}$

Jihad Jack also shares a comparative analysis with United States jurisprudence, but on the protection of civil rights. For example, Justice Kirby, citing his opinion in Fardon, ${ }^{432}$ reaffirms that "[a]lthough the constitutional setting in the United States is different from that operating in Australia, our legal tradition shares a common vigilance to the dangers of civil commitment that deprives persons of their liberty." 433 Similarly, Justices Gummow and Crennan discuss McCulloch v. Maryland, ${ }^{434}$ in analyzing the meaning of the term "necessary" in para (d) of section 104.4(1) of the Criminal Code, and refer to The Federalist in analyzing the scope of the defense power (section 51(vi)). ${ }^{435}$

Similarly, the common denominator in third-tier outliers remains the extensive reliance on United States jurisprudence. In Pastoral Leases Case, the comparison is on the native title in the United States. For example, Chief Justice Brennan explains the need for a "a treaty or a convention entered to pursuant to the Constitution." 436 Also, Justice Toohey compares United States and Australian property law, ${ }^{437}$ especially the powers to extinguish native title. ${ }^{438}$ Justice Gummow adds the following:

Quite apart from the treatment in the United States of native title, the American Revolution was followed in several of the States by legislative repudiation of the tenurial system as the ultimate root of real property title. For example, in New York the legislature abolished all feudal tenures of every description, with all their incidents, and declared that all lands within that State were allodial. ${ }^{439}$

Justice Kirby also looks comparatively at the United States. For example, he describes the effects of radical title in Australia, and the extinguishment of native title as follows:

$431 \quad I d$. at 463.

432 Fardon v A-G for Queensland (2004) 223 CLR 575, 641 (Austl.).

433 Jihad Jack Case, 233 CLR at 430 (Austl.).

434 McCulloch v. Maryland, 17 U.S. 316 (1819).

435 Jihad Jack Case, 233 CLR at 359 (Austl.). See Alexander Hamilton et al., The Federalist 200 (Benjamin Wright ed., 1961).

436 Pastoral Leases Case, 187 CLR at 96 (Austl.) (citing 25 U.S.C § 177).

437 Pastoral Leases Case, 187 CLR at 111 (Austl.) (referring to Brendan Edgeworth, Tenure, Allodialism and Indigenous Rights at Common Law: English, United States and Australian Land Law Compared after Mabo v Queensland, 23 Anglo-Am. L. Rev. 397 (1994)).

438 Pastoral Leases Case, 187 CLR at 123 (Austl.) (citing Johnson v. McIntosh, 21 U.S. 543, 587 (1823); United States v. Santa Fe Pac. R.R. Co., 314 U.S. 339 (1941); St. Catherine's Milling \& Lumber Co. v. R. (1888) 14 App. Cas. 46 (UK); Tee-Hit-Ton Indians v. United States, 348 U.S. 272, 279 (1955)).

439 Pastoral Leases Case, 187 CLR at 178 (Austl.) (citing Kavanaugh v. Cohoes Power \& Light Corp., (1921) 187 N.Y.S. 216, 236-37 (N.Y. Sup. Ct.); John ChipMan GraY, The Rule against Perpetuities $\$ 23$ (4th ed., 1942)). 
This apparently unjust and uncompensated deprivation of preexisting rights distinguished the treatment by the Crown of the indigenous peoples in Australia when compared to other settlements established under the Crown in the American colonies. ${ }^{440}$

Pape continued the comparative analysis with United States jurisprudence, for example on the standing issue, with Chief Justice French citing the Supreme Court to describe the relation between the federal government and tax payers as "shared with millions of others" and "comparatively minute and indeterminable." ${ }^{441}$ Chief Justice French also cites authorities rejecting the equating of the United States Constitution and sections 81 and 83 of the Australian Constitution. ${ }^{442}$ Similarly, Justices Gummow, Crennan and Bell look at the United States Constitution in interpreting section 83 of the Australian Constitution. ${ }^{43}$ There is similar analysis in the judgment of Justices Hayne and Kiefel. ${ }^{444}$

Mabo [No 2] exhibits the same comparative analysis with United States jurisprudence on native title. ${ }^{445}$ For example, Justice Brennan looks at United States cases when discussing the extinguishment of native title. ${ }^{446}$ Justices Deane and Gaudron also look at Unites States cases on the ability of the Crown to revoke or terminate native title. ${ }^{47}$ Justice Dawson also entertains the effect of United States jurisprudence on native title, in particular, the proposition that "traditional native title is not dependent upon a grant to or recognition of rights in the native inhabitants because such title is not dependent upon a treaty, statute or other formal government action." ${ }^{48} \mathrm{He}$ cites with approval the proposition that "Indian title in the United States (in the absence of recognition by Congress through treaty or legislation so that it becomes property within the meaning of the Fifth Amendment) is a right of occupancy which can be terminated by Congress at will", ${ }^{449}$ adding,

440 Pastoral Leases Case, 187 CLR at 206 (Austl.) (citing Cherokee Nation v. Georgia, 30 U.S. 1 (1831); Worcester v. Georgia, 31 U.S. 515 (1832); Menominee Tribe of Indians v. United States, 391 U.S. 404 (1968); Joint Tribal Council of the Passamaquoddy Tribe v. Morton, 528 F.2d 370 (1975); cf. Mabo [No 2] (1992) 175 CLR 1, 135-36 (Austl.)).

441 Massachusetts v. Mellon, 262 U.S. 447, 487 (1923). See Pape, 238 CLR at 34 (Austl.).

442 Pape, 238 CLR at 43-48 (Austl.) (citing U.S. ConsT. art. I, § 8, cl. 1).

443 Id. at 81 (citing U.S. ConST. art. I, § 9, cl. 7).

444 Id. at 112 (citing U.S. ConsT. art. I, § 8, cl. 1).

445 E.g., Mabo [No 2], 175 CLR at 90 (Austl.).

446 Mabo [No 2], 175 CLR at 63 (Austl.) (citing United States v. Santa Fe Pac. R.R. Co., 314 U.S. 339, 347 (1941); Tee-Hit-Ton Indians v. United States, 348 U.S. 272, 281-85 (1955)).

447 Mabo [No 2], 175 CLR at 90 (Austl.) (citing Tee-Hit-Ton Indians v. United States, 348 U.S. 272, 279 (1955); but cf. Johnson v. McIntosh, 21 U.S. 543, 587 (1823) and Cherokee Nation v. Georgia, 30 U.S. 1, 12 (1831)).

448 Mabo [No 2], 175 CLR at 129 (Austl.) (citing United States v. Santa Fe Pac. R.R. Co., 314 U.S. 339, 347 (1941); Narragansett Tribe v. S. Rhode Island Land Dev. Corp., 418 F. Supp. 798, 807 (D.R.I. 1976); Hamlet of Baker Lake v. Minister of Indian Affairs, [1980] 1 F.C. 518 (Can.)). See also Mabo [No 2], 175 CLR at 135 (Austl.) (Dawson J).

449 Mabo [No 2], 175 CLR at 136 (Austl.) (citing Oneida Indian Nation of N. Y. State v. Oneida, Cty.,414 U.S. 661, 667 (1974); Lipan Apache Tribe v. United States, 180 Ct. Cl. 487, 492 (1967); United States v. Santa Fe Pac. R.R. Co., 314 U.S. 339, 347(1941); Johnson v. McIntosh, 21 U.S. 543, 587-88 (1823); United States v. Tillamooks, 329 U.S. 40, 46 (1946); United States v. Atl. Richfield Co., ,435 F. Supp. 1009, 1031 (D. Alaska 
"[h]owever, Indian title will only be extinguished where Congress' intention to effect such extinguishment is "clear and plain." 450

What is clear from Justice Dawson's judgment is that he continues the same approach of distinguishing United States jurisprudence, especially when it comes to Aboriginal rights. Hence, he states that the "fiduciary relationship [that] exists between the United States government and the various Indian tribes", is not applicable in Australia, given that "the doctrine is dependent upon a history of protection of the Indian tribes, as separate domestic dependent nations with their own limited form of sovereignty and territorial and governmental integrity." 451 A similar discussion of United States jurisprudence and native title can be found in the judgment by Justice Toohey. ${ }^{452}$

The War Crimes Act Case also illustrates dependence on United States jurisprudence, and the what now can be described as a 'portmanteau' rejection of analogies with the United States Constitution. Chief Justice Mason analyzes the issue of retrospective law by looking at Supreme Court decisions, ${ }^{453}$ arguing that the prohibition in the United States "rests upon the existence of a specific prohibition in the United States Constitution which has no counterpart in [the Australian] Constitution. ${ }^{454}$ His honor makes the same argument in relation to bills of attainder. ${ }^{455}$

Justice Brennan, inter alia, looks at the "jurisdiction of the courts of the United States to try cases of international crime" arguing that this jurisdiction was "founded on the application by municipal courts of international law." ${ }^{456} \mathrm{He}$ also refers to United States cases trying war criminals after Civil War. ${ }^{457}$

Justice Deane also looks to the Supreme Court to support the proposition that " $[t]$ he ordinary object of the exercise of judicial power is the ascertainment of rights and liabilities or of guilt or innocence under the law." ${ }^{458}$ His honor looked at United States precedents when analyzing the effect of the doctrine of separation of powers, explaining that " $[\mathrm{t}]$ he doctrine of the separation of powers which is incorporated in the Constitution differs from that embodied in the United States Constitution in so far as the relationship between the legislative and executive arms of government is concerned." ${ }^{59}$ According to his honor, even the separation of judicial power under Chapter III of the Australian Constitution is different from that of the prohibitions

1977); Narragansett Tribe v. S. Rhode Island Land Dev. Corp., 418 F. Supp. 798, 807 (D.R.I. 1976); Gila River Pima-Maricopa Indian Cmty. v. United States, 494 F. 2d 1386, 1389 (Ct. Cl. 1974)).

450 Mabo [No 2], 175 CLR at 136 (Austl.) (citing Lipan Apache Tribe v. United States, 180 Ct. Cl. 487, 492 (1967)).

451 Mabo [No 2], 175 CLR at 164 (Austl.).

${ }_{452}$ Id. at 183-200 (citing U.S. ConST. art. I, §9, cl. 3 and art. I, § 10, cl. 1).

453 War Crimes Act, 172 CLR at 534 (Austl.).

454 Id.

455 Id. at 535.

456 Id. at 566-67.

457 Id. at 570 (citing Coleman v. Tennessee, 97 U.S. 509 (1878) and Dow v. Johnson, 100 U.S. 158 (1879)).

458 War Crimes Act, 172 CLR at 607 (citing Prentis v. Atl. Coast Line Co., 211 U.S. 210, 226 (1908)).

459 War Crimes Act, 172 CLR at 616 (Austl.). 


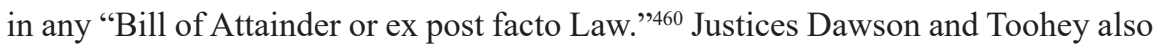
makes similar comparative analysis with United States jurisprudence. ${ }^{461}$

One can also find other comparative analysis in Williams [No 1]. Justices Gummow and Bell distinguished the "religious test clause" in the United States Constitution when analyzing section 116 of the Australian Constitution, ${ }^{462}$ as well as the doctrine in United States v. Butler, ${ }^{463}$ under which Congress has unlimited taxing and spending powers. ${ }^{464}$ While, in rejecting a wide view of the Commonwealth power to spend, Justice Hayne also looks at the United States Constitution when analyzing sections 81 and 83 of the Australian Constitution. ${ }^{465}$ As to Justice Heydon, he also looked at Article VI of the United States Constitution prohibition on the religious test. ${ }^{466}$ However, the rest of the judgments in School Chaplains, by Crennan and Kiefel, do not go into comparative analysis.

In summary, only the comparative analysis with the United States features in all twelve outliers, making it a common denominator that explains the high complexity seen in these cases. Moreover, the comparative analysis also informed other common themes in these outliers, including Aboriginal rights, the vertical power balance between State and Commonwealth governments, and on the way international law can inform domestic jurisprudence.

In the following section, the article explains the genesis of the rejection of SCOTUS interpretation of the United States Constitution as the most helpful aid for interpreting the Australian Constitution.

\section{REMOVING THE INEFFICIENCY IN INTERPRETING THE Australian CONSTITUTION}

As discussed below, the high complexity of HCA judgments over the last 100 years suggests inefficiencies in interpreting the Australian Constitution. This is, however, not only a historical problem, as can be seen in Figure 2 below. Out of the twelve outliers, half were decided in the $21^{\text {st }}$ century. If the HCA chooses to continue applying the Engineers Case, there can only be more paralysis in the actual operation of the Australian Constitution.

\footnotetext{
${ }_{460}$ Id. at 616 (citing U.S. ConST. art. I, $\$ 9$, cI. 3 (Federal) and art. I, §10, d. 1 (State): "the Bill of Attainder Clause")

461 Id. at 645-48, 660-89.

462 School Chaplains Case, 248 CLR at 223 (Austl.) (citing U.S. Const. art. VI, cl. 3). Section 116 reads as follows:

Commonwealth not to legislate in respect of religion:

The Commonwealth shall not make any law for establishing any religion, or for imposing any religious observance, or for prohibiting the free exercise of any religion, and no religious test shall be required as a qualification for any office or public trust under the Commonwealth.

463 United States v. Butler, 297 U.S. 1 (1936).

464 School Chaplains Case, 248 CLR at 231 (Austl.).

465 Id. at 245 (citing U.S. ConST. art. I, §8, cl. 1). Justice Hayne also refers to the proposition in Pape that "the power to spend appropriated moneys must be found either in provisions of the Constitution other than s 81 or s 83, or in statutes made under the Constitution" (School Chaplains Case, 248 CLR at 248 (Austl.) (citing Pape, 134 CLR at 412-413 (Austl.))).

466 School Chaplains Case, 248 CLR at 335 (Austl.).
} 
5

4

3

2

1

0

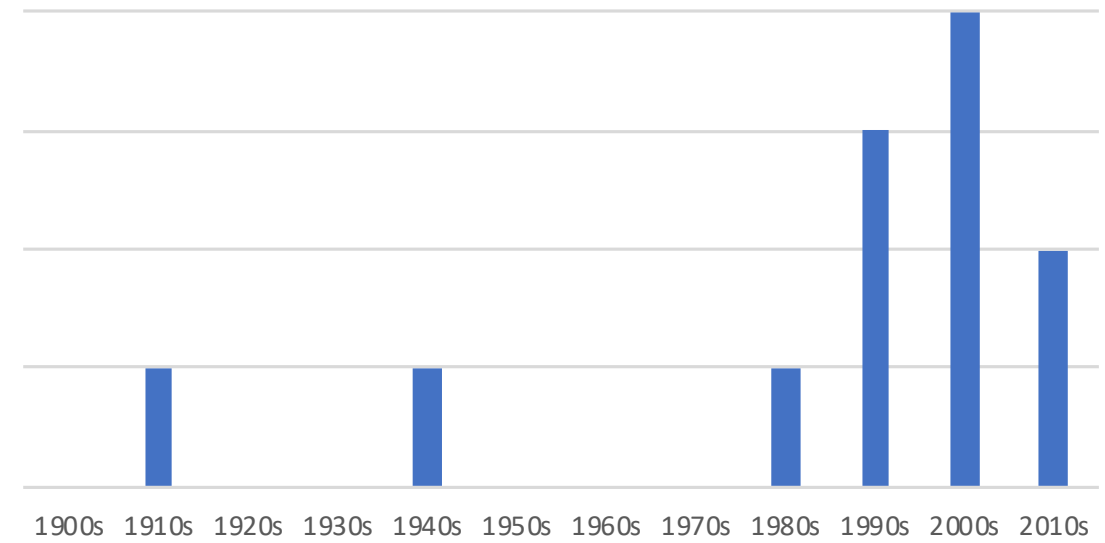

Figure 2: The frequency of outliers over the last twelve decades.

Since the passing of the Australia Acts, ${ }^{467}$ all appeals to the Judicial Committee of the Privy Council from state supreme courts have been eliminated, making section 74 of the Australian Constitution obsolete. ${ }^{468}$ However, the HCA has been reluctant to grant certificates of appeal to the Privy Council since its inception, exercising its discretion to grant appeal only once in $1912 .{ }^{469}$ The HCA explains this reluctance in the following terms:

There are various considerations which must govern the decision of this Court in exercising its power in a case which comes within s. 74. But no doubt the principle which lies at the root of s. 74 is one which must

467 See Australia Act 1986 (Cth) (Austl.), and Australia Act 1986, c. 2 (UK).

468 Section 74 reads as follows:

Appeal to Queen in Council:

No appeal shall be permitted to the Queen in Council from a decision of the High Court upon any question, howsoever arising, as to the limits inter se of the Constitutional powers of the Commonwealth and those of any State or States, or as to the limits inter se of the Constitutional powers of any two or more States, unless the High Court shall certify that the question is one which ought to be determined by Her Majesty in Council.

The High Court may so certify if satisfied that for any special reason the certificate should be granted, and thereupon an appeal shall lie to Her Majesty in Council on the question without further leave.

Except as provided in this section, this Constitution shall not impair any right which the Queen may be pleased to exercise by virtue of Her Royal prerogative to grant special leave of appeal from the High Court to Her Majesty in Council. The Parliament may make laws limiting the matters in which such leave may be asked, but proposed laws containing any such limitation shall be reserved by the Governor-General for Her Majesty's pleasure.

469 In Colonial Sugar Ref Co Ltd v Attorney-General (Cth) (1912) 15 CLR 182 (Austl.). 
be kept in mind as possibly paramount. It has been expressed by this Court in judgments before, but it may be very shortly summarized by the statement that experience shows - and that experience was anticipated when s. 74 was enacted that it is only those who dwell under a Federal Constitution who can become adequately qualified to interpret and apply its provisions. ${ }^{470}$

Notwithstanding this consciousness of the autochthonous prerequisite for interpreting the Australian Constitution, the origins of the high complexity seen in the twelve HCA decisions can be traced back to the marginalization of the framers' intention in cleaving closely to SCOTUS jurisprudence on the United States Constitution. The starting point to understanding the emerging constitutional crisis is to revisit the HCA decision in what came to be known as the Engineers Case. ${ }^{471}$

\subsection{THE LINGERING EFFECT OF THE ENGINEERS CASE}

In the Engineers Case, a national trade union served a list of claims on employers throughout Australia, including businesses owned by Western Australia, and began proceedings in the Commonwealth Arbitration Court. The Court had jurisdiction to settle industrial disputes, ${ }^{472}$ even if involving state or public authorities. The issue in the High Court was whether the Commonwealth had "power to make laws binding on the States with respect to conciliation and arbitration for the prevention and settlement of industrial disputes extending beyond the limits of one State." ${ }^{473}$ The HCA found the 1904 Act valid under the conciliation and arbitration power (section 51(xxxv)) of the Australian Constitution.

The case marked a move to a new interpretation of the Australian Constitution, one based on textualism rather originalism - in essence opting for British precedents on statutory construction. ${ }^{474}$ The earlier approach was to interpret the Australian Constitution based on the intention of the framers of the Constitution, of whom three were original judges of the HCA (Griffith, Barton and O'Connor) and two were appointed in 1906 (Isaacs and Higgins). The textual approach replaced the framers' intention with the intention of the British Parliament, who passed the Australian Construction. ${ }^{475}$ Samuel Griffith, the first Chief Justice of the HCA, explains originalism in these terms:

We cannot disregard the fact that the Constitution of the Commonwealth was framed by a Convention of Representatives from the several colonies. We think that, sitting here, we are entitled to assume - what, after all, is a fact of public notoriety - that some, if not all, of the framers of that Constitution were familiar, not only with the Constitution of the United States, but with that of the Canadian Dominion and those of the British

$470 \quad$ Whitehouse v Queensland (1961) 104 CLR 635, 637-38 (Austl.).

471 Engineers Case, 28 CLR 129 (Austl.).

472 See Conciliation and Arbitration Act 1904 (Cth) (Austl.).

473 Id. at $129,132$.

474 Engineers Case, 28 CLR at 149 (Austl.) (citing Ontario (Attorney-General) v. Canada (Attorney-General), [1912] A.C. 571, 583 (Can.)).

475 Commonwealth of Australia Act, 1900 (Imp), 63 \& 64 Victoria, c. 12 § (U.K.). 
colonies. When, therefore, under these circumstances, we find embodied in the Constitution provisions undistinguishable in substance, though varied in form, from provisions of the Constitution of the United States which had long since been judicially interpreted by the Supreme Court of that Republic, it is not an unreasonable inference that its framers intended that like provisions should receive like interpretation. ${ }^{476}$

This earlier approach was criticized by the majority (Knox, Isaacs, Rich, and Starke) in the following terms:

The more the decisions are examined, and compared with each other and with the Constitution itself, the more evident it becomes that no clear principle can account for them. They are sometimes at variance with the natural meaning of the text of the Constitution; some are irreconcilable with others, and some are individually rested on reasons not founded on the words of the Constitution or on any recognized principle of the common law underlying the expressed terms of the Constitution, but on implication drawn from what is called the principle of "necessity," that being itself referable to no more definite standard than the personal opinion of the Judge who declares it. ${ }^{477}$

However, the earlier approach was first criticized not by the HCA but by the Privy Council, who in 1906 stated that:

It is, indeed, an expansion of the canon of interpretation in question to consider the knowledge of those who framed the Constitution and their supposed preferences for this or that model which might have been in their minds. Their Lordships are not able to acquiesce in any such principle of interpretation. The legislature must have had in their minds the Constitution of the several States with respect to which the Act of Parliament which their Lordship are called upon to interpret was passed. ${ }^{478}$

The ensuing marginalization of SCOTUS jurisprudence paralyzed the interpretive coherence of the Australian Constitution, especially given the latter's brevity on issues such as (Aboriginal) rights, the federal compact, and the effect international law.

\subsection{The Proposed APPROACH}

The distribution of the twelve outliers suggests an ongoing 'constitutional crisis', where more efficiencies in interpreting the Constitution are likely to arise in the following decades. The origins of this crisis are summarized in the Bank Nationalization Case, when Justice Starke makes it clear that " [t]he decisions of the United States Courts are not authoritative upon the interpretation of the Australian

${ }^{476}$ D'Emden v Pedder (1904) 1 CLR 91, 113 (Austl.).

477 Engineers Case, 28 CLR at 141-42 (Austl.).

478 Webb v Outtrim (1906) 4 CLR 356, 360-61 (on appeal from Victoria) (Austl.). 
Constitution." ${ }^{\$ 49}$ Similarly, Justice Callinan's dissenting judgment in Ward, where he states the following:

I do not propose to refer to United States authorities upon which some of the claimants rely to maintain a claim to ownership of minerals. ${ }^{480}$ Those authorities are distinguishable by reason of the special treaty arrangements made with the Indian peoples whose lands were affected thereby and considered in those cases. ${ }^{481}$

In addition, in support of the dualist approach to international law, Justice Callinan states "the long settled principle that provisions of an international treaty do not form part of Australian law unless validly incorporated by statute." 482 The rationale for this approach being that "the separation of the legislative and executive arms of government necessitates that treaties be implemented domestically under statute." ${ }^{483}$ His honor then compares the Australian Constitution to the United States Constitution:

A contrast may be drawn with the position under the Constitution of the United States of America. Article VI of the United States Constitution relevantly provides: "This Constitution, and the Laws of the United States which shall be made in Pursuance thereof; and all Treaties made, or which shall be made, under the Authority of the United States, shall be the supreme Law of the Land." As a result, self-executing treaties can create rights and impose liabilities without being implemented by legislation passed in Congress.

The distinction is tenuous. A similar clause to Article VI of the United States Constitution was introduced into the 1891 draft of the Australian Constitution. However, the clause was eventually removed from the final version. The lack of references to international law in the Australian Constitution was, therefore, intentional. An early draft of the Australian Constitution included the following clause (adapted from the United States Constitution):

Operation of the Constitution and laws of the Commonwealth:

Clause 7. The Constitution established by this Act, and all laws made by the Parliament of the Commonwealth in pursuance of the powers conferred by the Constitution, and all Treaties made by the Commonwealth, shall, according to their tenor, be binding on the Courts, Judges, and people, of every State, and of every part of the Commonwealth, anything in the laws of any State to the contrary notwithstanding: and the Laws and Treaties of the Commonwealth shall

479 Bank Nationalization Case, 76 CLR at 306 (Austl.).

480 United States v. Shoshone Tribe of Indians of Wind River Reservation in Wyoming, 304 U.S. 111 (1938); United States v. Klamath \& Moadoc Tribes, 304 U.S. 119 (1938).

481 Ward, 213 CLR at 273 (Austl.).

482 Id. at 391.

483 Id. See also id. at 391-92, n1090. 
be in force on board of all British ships whose last port of clearance or whose port of destination is in the Commonwealth. ${ }^{484}$

This provision was later removed from the final version of the Australian Constitution, because "it was thought to have the unacceptable implication that Australia had the power to enter into international agreements independently of Great Britain." ${ }^{\prime 45}$ The amendment was introduced in the following terms:

I think it is expected by the Legislative Council of New South Wales that I should explain what the meaning of this amendment [to omit reference to treaties in clause 7] is. In the first place, the desire of that body is that, inasmuch as the treaty-making power will be in the Imperial Government, we should omit any reference to the making of treaties by the commonwealth; in other words, while they concede that we should make certain trade arrangements, which would have force enough if ratified by the Imperial Government, the sole treaty-making power is in the Crown of the United Kingdom. ${ }^{486}$

Query, however, whether this rationale still applies today, and therefore, whether cl. 7 does in fact have relevance in interpreting the Australian Constitution, as a virtually identical version of Article VI, that can be implied into the Constitution by the HCA using SCOTUS jurisprudence.

Similarly, in Polyukhovich, Justice McHugh provided a comparison in the following terms: $:^{487}$

The framers of our Constitution were much influenced by the model of the U.S. Constitution. They "felt the full fascination of its plan" ${ }_{488}$ Yet, although Chs I, II and III reflect Arts I, II and III of the United States model, our Constitution does not prohibit Bills of Attainder or ex post facto laws. The omission must have been deliberate. It is a powerful indication that the Parliament was intended to have the power to enact ex post facto laws. Furthermore, I have not seen anything in the historical materials which would indicate that the framers of the Commonwealth Constitution believed or assumed that giving a criminal statute a retrospective operation was an exercise of, or an interference with the exercise of, judicial power. Inglis Clark later wrote that "any exposition of the purport of the language of an existing law, or any declaration of the existence of any rights or liabilities as the result of its

484 George Burnett Barton, The Draft Bill to Constitute the Commonwealth OF Australia (2000), http://setis.library.usyd.edu.au/ozlit/pdf/fed0007.pdf (emphasis added).

485 Charlesworth, supra note 9 , at 4.

486 See Official Record of the Debates of the Australasian Federal Convention, Sydney, 9 September 1897, 239 (Edmund Barton), https://www.aph.gov.au/About_Parliament/ Senate/Powers_practice_n_procedures/Records_of_the_Australasian_Federal_ Conventions of the 1890s. (Emphasis added).

487 War Crimes Act Case, 172 CLR at 720-21 (Austl.).

488 Owen Dixon, Jesting Pilate: And Other Papers and Addresses 113 (1965). 
enactment, is not an exercise of legislative power ... it is an attempted encroachment on the province of the judiciary and is therefore invalid" ([McHugh J's] emphasis)". ${ }^{489}$ But he accepted that "[t]he Constitution does not prohibit the Parliament of the Commonwealth from making retroactive laws." ${ }^{\circ 90}$

Even when consulting historical material, Justice McHugh suggests that difference in form between the Australian and United States Constitutions, should be interpreted as deliberate, regardless of the rationale for such differences. Query, however, whether when reasons can be found in, for example, the records of the Australian Constitutional Convention Debates ${ }^{491}$ there should be a more nuanced approach.

In a more radical approach, the drafting history of the Australian Constitution was held by some justices to be irrelevant. In Work Choices, Justice Callinan makes extensive reference to United States jurisprudence, inter alia, in relation to the relevance of the United States Constitution to the Convention Debates (1891-1898), which culminated in the drafting of the Australian Constitution. ${ }^{492}$ He cites the Member for North Melbourne, Henry Bournes Higgins, and the delegates prejudice "in favor of certain theories which they had derived from the antiquated Constitution of the United States" ${ }^{493}$ in particular that residual powers should remain with the States, and therefore "that each State should be left to deal with its own labour conditions as it thought best." ${ }^{494}$ Justice Callinan was also clear on his textualist approach to the Australian Constitution, emphasizing "that the primary duty of a Justice of the High Court is to apply the language of the Constitution rather than other judicial decisions about it" ${ }^{495}$ although citing the fourth Storrs Lecture by Judge Benjamin N. Cardozo, ${ }^{496}$ where Cardozo states that "adherence to precedent should be the rule and not the exception." ${ }^{\prime 497} \mathrm{He}$ also uses the Tenth Amendment to explain the meaning of section 107 (saving of power of state parliaments) of the Australian Constitution. ${ }^{498}$

Similarly, Pape evinces arguments contra the framers' intention. Justice Heydon cites the following passages from two cases that suggests his approval of the way the Australian Constitution should be interpreted:

\footnotetext{
Andrew Inglis Clark, Studies in Australian Constitutional Law 39 (1901).

Id. at 39-40 (emphasis added).

491 Official Records of the Debates of the Australasian Federal Conventions of the 1890s, Parliament OF Australia, https:/www.aph.gov.au/About_Parliament/Senate/Powers practice_n_procedures/Records_of_the_Australasian_Federal_Conventions_of_the_1890s. 492 Work Choices Case, 229 CLR at 275 (Austl.).

493 Id. at 279 (citing Commonwealth, Parliamentary Debates, House of Representatives, 12 August 1903, 3467 (Henry Bournes Higgings) (Austl.)).

494 Work Choices Case (2006) 229 CLR 1, 281 (Austl.) (citing Henry Bournes Higgins, A New Province for Law and Order: Industrial Peace through Minimum Wage and Arbitration, 29 HaRv. L. Rev., 13, 13-14 (1915)).

495 Work Choices Case, 229 CLR at 311 (Austl.).

496 Benjamin N. Cardozo, The Nature of the Judicial Process 149-50 (1921).

497 Id.

498 Work Choices Case, 229 CLR at 343 (Austl.).
} 
[I]n 1819 Marshall CJ said in McCulloch v Maryland that "we must never forget that it is a constitution we are expounding". ${ }^{999}$ In the same case he said that constitutions are "intended to endure for ages to come, and consequently, to be adapted to the various crises of human affairs". ${ }^{500}$ In 1884, Gray J, in delivering the opinion of the Supreme Court of the United States, said:501 "A constitution, establishing a frame of government, declaring fundamental principles, and creating a national sovereignty, and intended to endure for ages and to be adapted to the various crises of human affairs, is not to be interpreted with the strictness of a private contract". ${ }^{502}$

Justice Heydon goes on to explain that

These passages do not suggest that their authors believed that the meaning of either the United States or the Australian Constitution changed over time. They rather suggest that their authors believed that, while the meaning did not change, the meaning was broad. As Scalia J wrote: ${ }^{03}$ "Marshall was saying that the Constitution had to be interpreted generously because the powers conferred upon Congress under it had to be broad enough to serve not only the needs of the federal government originally discerned but also the needs that might arise in the future. If constitutional interpretation could be adjusted as changing circumstances required, a broad initial interpretation would have been unnecessary." ${ }^{504}$

However, his honor then suggests that "[r]eference to history is not permitted for the purpose of substituting for the meaning of the words used in the Constitution the scope and effect which the framers subjectively intended the Constitution to have", ${ }^{505}$ and that "The unusual course of drawing originalist inferences from negatives to support conclusions about the mental state of the framers is impermissible." 506

This reluctance to patriate the Australian Constitution to its originalist inferences is at the crux of the complexity observed in the HCA interpretation of the Constitution. As expressed in Work Choices by Justice Callinan:

Part, indeed an essential, if not the most illuminating, aspect of the history of the Constitution is the language of the founders in the Convention Debates with respect to the provisions which they debated at great length, at much greater length it may be said, than the authors of the United States Constitution, but with the advantage of a sound knowledge of that

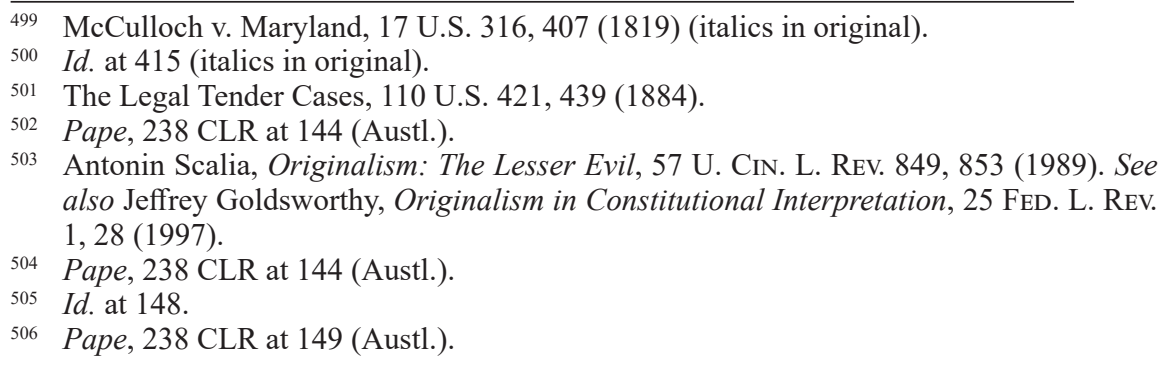


Constitution and how it had operated and been construed for more than 100 years. ${ }^{507}$

Contrast the above statements with the following balanced approach, also from the Bank Nationalization Case, where Justice Dixon then goes on to compare Article III to section 75(iii) and states the following:

[I]t is apparent that when the framers of the Commonwealth Constitution took up the study of the Constitution of the United States with a view to modelling upon it the new Australian instrument of Government, and reached the clause in question, the first difficulty they must have encountered was to say how stood suits against officers and agents of the United States. We may be permitted to know as a matter of history that what is now s. 75(iii) appeared in its present form in the draft Constitution presented at the Convention of 1891 and that before it so emerged it had gone through the hands of Sir Samuel Griffith who had before him the report of the Judicial Committee over which Inglis Clark J presided.

Anyone who takes Article Ill of the American Constitution and acquaints himself with the difficulties that arose under it and the manner in which they were dealt with by the Supreme Court and Congress and then compares it with Chapter Ill of [the Australian] Constitution will at once see that the text of the latter is the outcome of much knowledge of the judicial exegesis by which judicial power of the United States has been defined. The addition of the words "or a person suing or being sued on behalf of the Commonwealth" appear appropriate to ensure that the jurisdiction over matters in which the Commonwealth is a party should not be limited to cases in which the Commonwealth is a party on the record and to ensure that on the contrary it covered officers and agencies of the Government sued or suing in their official or governmental capacity such as those whose position had been the cause of so much trouble in the United States. ${ }^{508}$

In his analysis, Justice Dixon employs two principles: a principle of implication of the United States Constitution into the Australian Constitution, and a principle of equivalence between the United States and Australian Constitutions. The first principle is based on the framers" "view to modelling" upon the former "the new Australian instrument of Government." "509 The second is based on the framers" "study of the Constitution of the United States" and their acquaintance with "difficulties that arose under" the United States Constitution. ${ }^{510}$ In his analysis his honor then uses SCOTUS jurisprudence to ascertain the intention behind using additional or different words used in the Australian Constitution. In some situations, as we saw

507 Work Choices Case, 229 CLR at 275 (Austl.).

508 Bank Nationalization Case, 76 CLR at 366-67 (Austl.) (citing United States v. ThayerWest Point Hotel Co., 329 U.S. 585, 589 (1947)).

509 Bank Nationalization Case, 76 CLR at 366-67 (Austl.).

510 Id. 
earlier in Chief Justice Mason's judgment, in the Tasmanian Dam Case, ${ }^{511}$ variance in form is not authority to an intention to produce a result not available under the United States Constitution. For such authority, there has to be SCOTUS cases or Convention debates that explain the rationale for the changes made.

This analytical framework, based on the implication and equivalence principles, encapsulates the proposed optimal interpretive approach.

In summary, an efficient interpretation of the Australian Constitution must first patriate the Constitution, by ensuring that its interpretation rests on the intention of its Australian framers, rather than the intentions of the British Parliament who passed the Act within which the instrument is found. ${ }^{512}$ That intention can be ascertained from the records of the Australasian federal Conventions of the 1890s, including the $1891 \mathrm{draft}$ and other writings of the framers. The records suggest two guiding interpretive principles. The first is the implication principle, where the Australian Constitution is held to be modelled on the United States Constitution, and therefore implying its constitutional principles into the Australian Constitution, including, for example, its Bill of Rights (based on the first ten Amendments and the Fourteenth Amendment). The implication does not obtain from what is in the Constitution, but from the intention of the framers. Hence, even though there was never a bill of rights in any of the Constitution's drafts, the fact that the framers intended to have such protections, and the reasoning given for declaring such protections redundant, necessitates implying the bill into the Constitution when said redundancy has not materialized. This particular implication is discussed in more detail below.

The second principle is that of equivalence, where Australian provisions are presumed to cleave particularly closely to their US counterparts. As suggested by Chief Justice Griffith, ${ }^{513}$ differences in form, should not trump equivalence in substance. SCOTUS jurisprudence and the Convention debates are then used to ascertain any difficulties with the US form that could have been the reason for any difference in form. The equivalence principle is based on the deep understanding that the framers had for SCOTUS jurisprudence. For example, Justice Kirby explains:

[Andrew Inglis] Clark's legislation bore the mark of his progressivist and humanitarian values. The laws he sponsored included legalization of trade unions; the prevention of cruelty to animals; providing allowances to members of Parliament; and reforming the laws on lunacy and the custody of children. In one dispute over a railway line, which the government had lost before the colonial Supreme Court, he advised an appeal to the Privy Council in London. He travelled to England in 1890 to conduct the case. His experience in seeing most of the Law Lords asleep during the appeal reinforced his view that appeals to the Privy Council should be terminated. Pursuing both his political and spiritual interests (he was a Unitarian), Clark made the first of three visits to the United

\footnotetext{
511 See Chief Justice Mason's emphasis on the distinction between "taking" and "acquisition" in Tasmanian Dam Case, 158 CLR at 144-45 (Austl.).

512 Namely, Commonwealth of Australia Constitution Act, 1900 (Imp), 63 \& 64 Victoria, c. $12, \S 9$ (UK).

513 D'Emden, 1 CLR at 113 (Austl.), discussed further in the next section.
} 
States where he became increasingly familiar with the Constitution-a subject on which he wrote frequently to Oliver Wendell Holmes Jr, also a Unitarian. Clark returned to Hobart convinced of the relevance and utility of the United States Constitution for Australian's future federal governance..$^{514}$

The equivalence principle rests on solid grounds, in the scholarship of the framers of the Australian Constitution, and their resolve to create a federal compact that emulated that in the United States.

The next section fleshes out the proposed interpretive approach through application to one of the more recent HCA judgments on freedom of speech and expression.

\subsection{AN APPLICATION OF THE PROPOSED APPROACH}

It is useful to provide an example of how the proposed approach can be applied by the HCA, by reference to a recent case. In August 2019, the HCA delivered a judgment in the case of Michaela Banerji, a former employee of the Department of Immigration and Border Protection. ${ }^{515}$ Banerji had been fired by the Department after an internal investigation found that her criticism of the Department's policies through a Twitter handle breached the Australian Public Servants' (APS) Code of Conduct ${ }^{516}$ - notwithstanding that the account was under a pseudo name. In the Federal Circuit Court, Banerji failed to obtain an injunction to stop the termination of her employment, as there was no free speech right in Australia. ${ }^{517}$ After termination, her application for workers' compensation was rejected on the ground that the termination was reasonable. ${ }^{518} \mathrm{On}$ appeal to the Administrative Appeals Tribunal (AAT), the AAT found that the termination was unreasonable given the nature of the comments made by Banerji on the Twitter account and her role as a public servant. ${ }^{519}$ The AAT decision was appealed to the Federal Court, and the Commonwealth Attorney-General removed the dispute to the HCA. The HCA upheld the appeal unanimously. In the majority joint judgment, the court reiterated that in Australia there is no 'personal right' protecting freedom of speech. ${ }^{520}$

The Banerji decision reignited the debate around the necessity of an Australian bill of rights. It has been suggested that this is a matter of 'national urgency', given

\footnotetext{
514 Michael Kirby, Reviving the Memory of Andrew Inglis Clark: An Unfinished Federal Project, 34 U. TAS. L. Rev. 92, 95 (2015).

515 Comcare v Banerji (2019) 93 ALJR 900. (Austl.). The Department name was later changed to the Department of Immigration and Citizenship (DIAC).

516 Under the Public Service Act 1999 (Cth) (Austl.), Banerji was required to 'at all times behave in a way that upholds the APS Values' (s 13(11)). Among the APS Values was a declaration that 'the APS is apolitical, performing its functions in an impartial and professional manner' (s 10(1)). These sections - collectively the APS Code of Conducthave subsequently been amended, but the changes are not material.

517 Banerji v Bowles [2013] FCCA 1052, \ 101 (Austl.).

518 See Safety, Rehabilitation and Compensation Act 1988 (Cth) (Austl.).

519 Re Banerji and Comcare (Compensation) [2018] AATA 892, \ 116 (Austl.).

${ }_{520}$ Comcare v Banerji (2017) 93 ALJR 900, 909 (Austl.).
} 
that Australia is "the only Western democracy without some form of charter of rights legislated by Parliament or entrenched in the constitution'. ${ }^{521}$

As to the protection of rights, one point of particular relevance to the proposed approach comes from Justice Heydon, who looks to the Supreme Court to ascertain the meaning of "judicial power", ${ }^{22}$ citing Chief Justice Marshall in Osborn v. Bank of the United States, ${ }^{523}$ and in Wayman v. Southard. ${ }^{524}$ Justice Heydon distinguishes the operation of the Australian and United States Constitutions in the following terms: "The Constitution does not contain express guarantees to establish individual rights of the kind set out in the Fourteenth Amendment to the United States Constitution, which guarantees would have restricted state legislatures. That was left to the rule of law." ${ }^{525}$ His honor's point in relation to the Fourteenth Amendment extends to all rights Amendments in the United States Constitution, including First Amendment protection of freedom of speech from government restrictions.

The lack of an Australian bill of rights reflects the views expressed by those who framed the Australian Constitution in the 1890s. ${ }^{526}$ The question of rights protections was championed by Andrew Inglis Clark, the then Tasmanian AttorneyGeneral, who did not propose a US-style bill of rights but included several rights protections in the Draft Constitution. Some delegates shared Clark's concerns as to the protection of rights. For example, Richard O'Connor was concerned that laws passed by majorities were not always just:

I rise for the purpose of pointing out the position in which we stand, and to express the hope that, having discussed this matter so fully, we may soon come to a division. The honorable and learned member [Bernhard Ringrose Wise] has proposed an amendment which, if carried, will involve the declaration that the citizens of each state are citizens of the Commonwealth. I have already dealt with the general aspect of this provision, but I should like to ask the committee what is meant by the term 'citizen'? What rights shall we give to a man as a citizen? If we do not give any definite rights, what is the use of placing in the Constitution a provision which will be a fruitful source of litigation?527

521 Gillian Triggs, Why an Australian Charter of Rights is a Matter of National Urgency, THE CONVERSATION (Aug. 13, 2019, 5:12 AM), https://theconversation.com/why-an-australiancharter-of-rights-is-a-matter-of-national-urgency-121411; Binoy Kampmark, Freedom of Speech: The Powerful Chill of the Banerji High Court Decision, InDEPENDENT Australia (Aug. 13, 2019, 8:00 AM), https://independentaustralia.net/politics/politics-display/ freedom-of-speech-the-powerful-chill-of-the-banerji-high-court-decision,12996. See also Kieran Pender, 'A Powerful Chill?' Comcare v Banerji [2019] HCA 23 and the political expression of public servants, Australia Public Law (Aug. 28, 2019), https://auspublaw. org/2019/08/a-powerful-chill-comcare-v-banerji-2019-hca-23/.

522 Momcilovic, 245 CLR at 155 (Austl.).

523 Osborn v. Bank of U.S., 22 U.S. 738, 866 (1824).

524 Wayman v. Southard, 23 U.S. 1, 46 (1825).

525 Momcilovic, 245 CLR at 216 (emphasis added).

526 Paul Kildea, The Bill of Rights Debate in Australian Political Culture, 9 Australian. J. Hum. RTs. 65 (2003). See also George Williams, The Victorian Charter of Human Rights and Responsibilities: Origins and Scope, 30 MeLb. U. L. Rev. 880, 883-85 (2006).

527 Official Record of the Debates of the Australasian Federal Convention, Melbourne, 8 February 1898, 682 (Richard O'Connor), https://www.aph.gov.au/About_Parliament/ 
However, few delegates agreed. Most of the convention delegates believed that individual rights were adequately protected by the common law and the rule of law - the same argument raised by Justice Heydon in Momcilovic (see above). The idea of rights protections was also said to be contrary to the notion of parliamentary sovereignty-yet another British concept. For example, Victorian delegate William Trenwith said:

\begin{abstract}
The honorable member who has just sat down [O'Connor] has assumed a possible difficulty that I cannot conceive is likely to occur. He assumes that unless we define clearly what we mean by citizenship, the Federal Parliament may take such action as will infringe some liberties which we now possess, and which we ought to possess. When we remember that we have provided in the Constitution that both Houses of Parliament shall be elected on the broadest possible franchise, it seems to me to be utterly impossible to conceive that such a Parliament will proceed to infringe any of the liberties of the citizens. ${ }^{528}$
\end{abstract}

The result was the establishment of a constitutional system that, consistent with utilitarian philosophy, secured the expression of the majority's will. The Australian Constitution, which came into force on 1 January $1901,{ }^{529}$ contained only three provisions that related directly to human rights: ${ }^{.30}$ trial by jury for indictable offences (section 80), freedom of religion (section 116) and a limitation on discrimination based on state residence (section 117). The constitutional design was utilitarian, befitting the political culture of the day. ${ }^{531}$

Query, however, a situation like in Banerji, where the Commonwealth Parliament infringes on the liberties of citizens. To understand this point, it is useful to unpack the AAT decision. ${ }^{532}$ At the tribunal, Banerji argued that her termination was unreasonable, in breach of the implied freedom of political communication as identified by the High Court in Lange. ${ }^{533}$ The legal issue was whether the termination of Banerji's employment falls outside the relevant Commonwealth compensation Act,${ }^{534}$ having regard to the implied freedom of political communication. ${ }^{535}$ The AAT looked at the circumstances surrounding Banerji's tweets, finding that she tweeted

Senate/Powers_practice_n_procedures/Records_of_the_Australasian_Federal_ Conventions_of the $1890 \mathrm{~s}$.

528 Official Record of the Debates of the Australasian Federal Convention, Melbourne, 2 March 1898, 1761 (Hackett Trenwith), https://www.aph.gov.au/About_Parliament/ Senate/Powers_practice_n_procedures/Records_of_the_Australasian_Federal_ Conventions_of_the_1890s (emphasis added).

529 Commonwealth of Australia Constitution Act 1900 (Imp), 63 \& 64 Victoria, c 12, s 9 (Austl.).

530 See Rosalind Dixon, An Australian (Partial) Bill of Rights, 14 InT'L J. Const. L. 80 (2016) (argues that the Australian Constitution contains an extremely narrow bill of rights).

531 See generally, Kildea, supra note 526.

532 Banerji, [2018] AATA 892 (Austl.).

533 Lange v Australian Broadcasting Corporation (1997) 189 CLR 520 (Austl.).

534 Safety Rehabilitation and Compensation Act 1988 (Cth) (Austl.).

535 Banerji, AATA 892 at $\uparrow 38$ (Austl.). 
in the course of her employment. ${ }^{536}$ The Tribunal then looked at the Department guidelines, finding online unofficial comments to be permitted within certain requirements. ${ }^{537}$ After a comparative analysis with Canadian jurisprudence, ${ }^{538}$ the Tribunal found:

Patently, the stated purpose of the APS and Department Guidelines are not well served when the guidelines are applied to anonymous comment by public servants ... a law purporting to prevent anonymous expressions of opinion, whatever the situation of the person using that medium, surely requires powerful and persuasive justification for its existence if it is to displace the implied freedom of political communication. Almost all of the public policy considerations underpinning restrictions on the statements of public officials, including senior public servants and military officers, cease to apply where the identity of the interlocutor is unknown. On the contrary, restrictions in such circumstances bear a discomforting resemblance to George Orwell's thoughtcrime. ${ }^{539}$

In the Federal Circuit Court, Judge Neville also looks at United States jurisprudence, stating that:

103. Likewise, in the same case [Attorney-General for South Australia $v$ Corporation of the City of Adelaide (Corneloup's Case)], ${ }^{540}$ at [151] and [152], Heydon J confirmed the obvious point that the Australian Constitution does not contain provisions similar to the First and Fourteenth Amendments of the United States' Constitution...

104. As already observed, the unfettered right asserted by the Applicant does not exist. In the circumstances outlined in the current matter, and certainly only in the context of an interlocutory Application, I do not see that Ms Banerji's political comments, 'tweeted' while she remains (a) employed by the Department, (b) under a contract of employment, (c) formally constrained by the APS Code of Conduct, and (d) subject to departmental social media guidelines, are constitutionally protected. Further, it makes no difference, and actually strengthens the case against granting the relief she seeks, that her "tweets" occurred (in part or in full) while she was also professionally retained or engaged in employment outside her duties with the Department, and in relation to which she has/ had no formal permission from the Department to be so employed. ${ }^{541}$

In the HCA, the Court refused to entertain the "anonymous" communications argument raised by Banerji, given "the argument differed fundamentally from the

536 Id. at 930.

537 Id. at 137.

538 Id. at 79.

539 Id. at 116.

540 Attorney-General (SA) v Corp of the City of Adelaide (2013) 249 CLR 1 (Austl.).

541 Banerji v Bowles [2013] FCCA 1052 (9 August 2013) (Austl.). 
way in which the respondent put her case before the Tribunal. ${ }^{, 542}$ Instead, Chief Justice Kiefel and Justices Bell, Keane and Nettle rejected the implied freedom argument, stating that:

In the result, the respondent's implied freedom argument amounts in effect to saying that, despite the fact that her conduct in broadcasting the "anonymous" tweets was conduct which failed to uphold the APS Values and the integrity and good reputation of the APS, Parliament was precluded from proscribing the conduct because its proscription imposed an unjustified burden on the implied freedom of political communication. To say the least, that is a remarkable proposition..$^{543}$

They went on to reiterate that the implied freedom of political communication was not "a personal right like ... the freedom of speech guaranteed by the First Amendment to the Constitution of the United States." ${ }^{444}$ The Majority explained the nature of the implied freedom in the following terms:

It is a restriction on legislative power which arises as a necessary implication from ss 7, 24, 64 and 128 and related sections of the Constitution and, as such, extends only so far as is necessary to preserve and protect the system of representative and responsible government mandated by the Constitution. Accordingly, although the effect of a law on an individual's or a group's ability to participate in political communication is relevant to the assessment of the law's effect on the implied freedom, the question of whether the law imposes an unjustified burden on the implied freedom of political communication is a question of the law's effect on political communication as a whole. More specifically, even if a law significantly restricts the ability of an individual or a group of persons to engage in political communication, the law will not infringe the implied freedom of political communication unless it has a material unjustified effect on political communication as a whole. ${ }^{545}$

The HCA reasoning rests on an "implied freedom of political communication", which does not amount to the protections afforded by the Frist Amendment. If, however, we were to apply the proposed interpretive framework, the starting point is to look at SCOTUS jurisprudence on public employee speech. For example, in Pickering $v$. Board of Education, ${ }^{546}$ Marvin L. Pickering, a public-school teacher, wrote a letter to the New York Times criticizing the allocation of financial resources at his school. The school Board argued that: "the teacher by virtue of his public employment has a duty of loyalty to support his superiors in attaining the generally accepted goals of education and that, if he must speak out publicly, he should do so factually and

\footnotetext{
Comcare v Banerji (2017) 93 ALJR 900, 910 (Austl.).

Id. at 911-12.

544 Id. at 909.

545 Id. at 910.

546 Pickering v. Bd. of Educ., 391 U.S. 563 (1968).
} 
accurately, commensurate with his education and experience." ${ }^{547}$ In dispensing with this argument, Marshall J's majority opinion rejected categorically the propositions that "teachers may constitutionally be compelled to relinquish the First Amendment rights they would otherwise enjoy as citizens to comment on matters of public interest in connection with the operation of the public schools in which they work." 548 Justice Marshall found that the government interests did not outweigh Pickering's freedom of speech. ${ }^{549}$ Absent any malicious libel of the school Board, actionable under the New York Times standard, Pickering could not be dismissed. ${ }^{550}$

The Pickering Principle was applied in Connick v. Myers, ${ }^{551}$ were a five-tofour majority found that striking the right balance between free speech and public employment did not extend to internal office matters. In this case, the employee was Sheila Myers, an assistant district attorney in New Orleans. She objected to the office transfer policy, and distributed a questionnaire to 15 assistant district attorneys soliciting their views on the policy. In finding that the termination of her employment did not violate the Free Speech Clause, Justice White explained that the holding was narrow, "[w]e hold only that when a public employee speaks not as a citizen upon matters of public concern, but instead as an employee upon matters only of personal interest, absent the most unusual circumstances, a federal court is not the appropriate forum in which to review the wisdom of a personal decision taken by a public agency allegedly in reaction to the employee's behavior." ${ }^{\text {"52 }}$ More to the point of comparison with the implied freedom in Australia, his honor cites the following statement: "[T] he First Amendment does not protect speech and assembly only to the extent it can be characterized as political. 'Great secular causes, with smaller ones, are guarded." "'553

In Lane v. Franks ${ }^{554}$ SCOTUS updated and clarified the Pickering principle. In Lane, the president of the Central Alabama Community (CACC) terminated the employment of the Director of a program for underprivileged youth directed by CACC. The Director, Lane, sued the President, Franks, in his individual and official capacities, ${ }^{555}$ alleging retaliation for testifying against Schmitz, a state representative on the payroll of the youth program. Justice Sotomayor re-stated the principle as follows:

Almost 50 years ago, this Court declared that citizens do not surrender their First Amendment rights by accepting public employment. Rather, the First Amendment protection of a public employee's speech depends on a careful balance "between the interests of the [employee], as a citizen, in commenting upon matters of public concern and the interest of the State, as an employer, in promoting the efficiency of the public services it

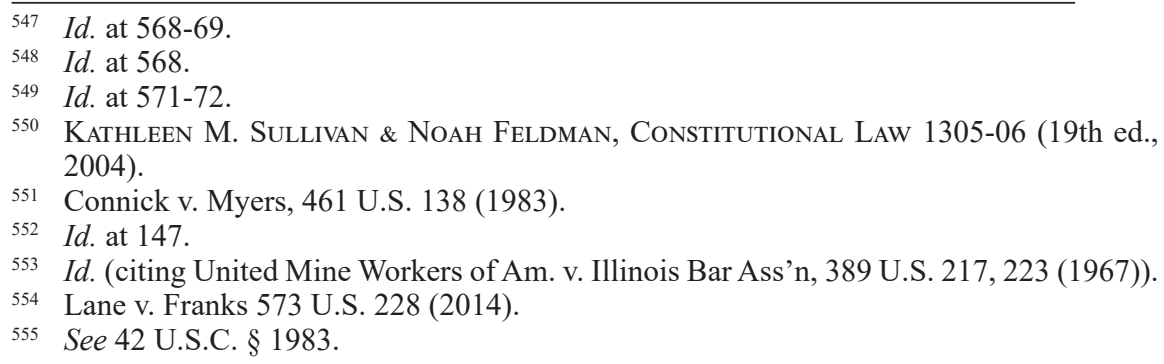


performs through its employees." Pickering v. Board of Ed. of Township High School Dist. 205, Will Cty., 391 U. S. 563, 568 (1968)..$^{556}$

Under the proposed interpretive framework, the Frist Amendment is implied into the Australian Constitution. The equivalence principle is not enlivened given that the Australian Constitution does not have any provisions based on the First Amendment. The analysis would then proceed to apply the Pickering principle as updated in Lane. Under the Pickering principle, "if an employee speaks as a citizen on a matter of public concern", ${ }^{557}$ the next step is to ask

whether the government had "an adequate justification for treating the employee differently from any other member of the public" based on the government's needs as an employer. ${ }^{558}$

The involved balancing exercise requires

"[balancing] the interests of the [public employee], as a citizen, in commenting upon matters of public concern and the interest of the State, as an employer, in promoting the efficiency of the public services it performs through its employees." 391 U.S., at 568, 88 S.Ct. 1731.559

Even setting aside the "anonymous" nature of Banerji's tweets, it is difficult to see the interests of the government in promoting the efficiency of the public services in preventing tweets by Banerji in her capacity as a citizen. For example, in its examination of the Public Service Act 1999 (Cth) ("PSA"), which sets out, inter alia, the Australian Public Servants (APS) values and the Code, the Administrative Appeals Tribunal (AAT) also looked at the guidelines promulgated by the Department of Immigration and Citizenship (DIAC) on the use of social media, where it is stated that

DIAC employees may generally make comment in their private capacity; however, if must be clear they are expressing their own view having regard to the general principles set out below.

These principles declare as inappropriate making comments that compromise or perceived to compromise the ability of the DIAC to perform its duties, or the public confidence in DIAC or APS. It also declared not appropriate "harsh or extreme criticism of the government, a member of parliament or political party..."; or "strong criticism of DIAC administration that could disrupt the workplace."

However, section 13(11) of the PSA provides that "An APS employee must at all times behave in a way that upholds the APS Values and the integrity and good reputation of the APS..."

\footnotetext{
Id. at 231 .

Id. at 242.

558 Garcetti, 547 U.S., at 418, 126 S.Ct. 1951.

559 Id. at 236.

560 Banerji and Comcare (Compensation) [2018] AATA 892, ๆ 36 (Austl.).
} 
The AAT found that:

The phrase at all times must reasonably be construed as requiring this behavior both when an employee is working and when she is not ... The requirements to uphold the values (which are defined with specificity in s 10) and the good reputation of the APS must necessarily preclude an employee who does not share those values, or who wishes to cast aspersions on the reputation of the APS or a department within it, from expressing those views, including where to do so amounts to communication on the subjects of politics and government ... Both parties contended that the Code does in fact burden the freedom of political communication, with Comcare noting that the burden falls on a narrow class of persons and is narrow in its restriction on political communication. ${ }^{561}$

Given the blanket ban on public comments, and given that under the First Amendment, the balancing exercise is with a constitutional protected right of freedom of speech, the outcome would be different. The HCA decision would have found the PSA invalid under the Australian Constitution. The AAT outcome was similar to the proposed approach because of their reliance on Canadian jurisprudence under a similar constitutional protection, namely, The Canadian Charter of Rights and Freedoms. ${ }^{562}$

\section{THE WAY FORWARD}

A constitutional crisis is emerging in Australia, as captured by the complexity of HCA judgments involving constitutional issues, which is leading to inefficiencies in interpreting the Australian Constitution. The proposition is illustrated through an analysis of all HCA judgments from 1903-2020 (see Figure 1 and Figure 2). Cases exhibiting high complexity share a common denominator, namely a comparative analysis with United States constitutional jurisprudence, where under the principle in the Engineers Case, there is preference for British constitutional concepts (such as representative government and the rule of law), over the federal design found in the United States Constitution. This approach marginalized the original intent of the framers of the Australian Constitution, who saw in the United States model an ideal to be followed in the design of the Australian instrument.

This article calls for patriating the Australian Constitution - an Act of the British Parliament, not as opted for in Canada, but a judicial patriation that see the Constitution interpreted not following the intention of the British Parliament, but following the framers' intention, as evidenced, inter alia, in the Constitutional debates (1890-1898) leading to its adoption by the Australian people. The drafting history of the Australian Constitution should be accepted by the HCA as "indicative of an intention on the part of the framers to cleave particularly closely to" SCOTUS jurisprudence, especially on the interpretation of the United States Constitution. ${ }^{563}$

\footnotetext{
$I d$. at 69 (emphasis in the original).

Id. at 9 ๆ 79-89.

563 The quote comes from the HCA judgment in Re Canavan where it was held that the drafting history was of little use to interpreting s 44(i) (disqualification of parliamentarians for holding dual citizenship), Re Canavan (2017) 263 CLR 284, 304 (Austl.).
} 
This patriation can be actioned using a number of different approaches that revive the critical role of US constitutional jurisprudence in enlivening the framers' intention. For example, in Work Choices, Justice Kirby provided a useful synopsis of the possible approaches for interpreting the Australian Constitution, in stating that

The United States Supreme Court has lately found innovative ways to uphold the role of the States within the federal system and to enforce limits on the powers of Congress without doing undue damage to the national demands of efficiency, prosperity and security. ${ }^{564}$ Efforts like these balance the competing values that frame the American constitutional system. This Court should be no less attentive to the federal character of the Australian Constitution. ${ }^{565}$

The approach in this article is based on an implication-equivalence framework. The framework informs the ongoing debated on the need for an Australian Bill of Rights. The recommendation is to redefine the debate on an Australian bill of rights as one in relation to a (constitutional) recognition of human rights through the interpretation of the Australian Constitution based on the framers' intention in affording citizens under the Commonwealth the same protections they studied under the United States Constitution.

The framework is provided for illustrative purposes rather than as a complete interpretive theory. The purpose is to open new research possibilities on the role of the HCA in embracing SCOTUS jurisprudence when interpreting the Australian Constitution. The framework itself requires more analysis on implication and equivalence, in particular through deeper analysis of the available historical record of Convention debates and the scholarship of the framers, including on the HCA bench.

564 His honor refers to the following authorities: National League of Cities v. Usery, 426 U.S. 833 (1976); Hughes v. Alexandria Scrap Corp., 426 U.S. 794 (1976); Reeves, Inc. v. Stake, 447 U.S. 429 (1980); White v. Massachusetts Council of Const. Employers, Inc., 460 U.S. 204 (1983); United States v. Lopez, 514 U.S. 549 (1995); United States v. Morrison, 529 U.S. 598 (2000); Anthony B. Sanders, The 'New Judicial Federalism' Before Its Time: A Comprehensive Review of Economic Substantive Due Process Under State Constitutional Law Since 1940 and the Reasons for Its Recent Decline, 55 Aм. U. L. Rev. 457 (2005).

565 Work Choices Case, 229 CLR at 245 n 856 (Austl.). 